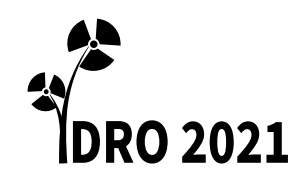

\title{
XLII.
}

Dny radiační ochrany

sborník abstraktů

8.- -12.11 .2021$

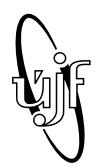
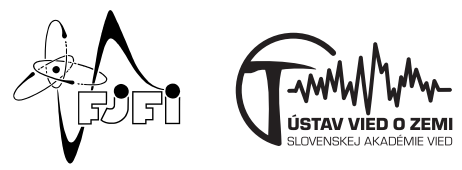

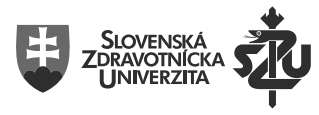

Ústav jaderné fyziky AV ČR, v.v.i.

Ústav vied o zemi Slovenskej Akadémie vied

Fakulta jaderná a fyzikálně inženýrská ČVUT v Praze

Slovenská zdravotnícka univerzita 


\section{Programový výbor:}

Marie Davídková, Iveta Smetanová

Ludmila Auxtová

Karol Böhm

Silvia Dulanská

Eva Fojcíková

Aleš Froňka

Robert Hinca

Jiří Hůlka

Irena Koniarová

Irena Malátová

\section{Organizační výbor:}

\section{Václav Štěpán, Ján Kubančák}

Kamil Augsten

Šimon Brabec

Silvia Dulanská

Marie Davídková

Terézia Melicherová

Anna Jelínek Michaelidesová

Radim Možnar

Simona Možnarová

Ondřej Kořistka
Denisa Nikodemová

Karla Petrová

Pavol Povinec

Petr Průša

Zdeněk Rozlívka

Lucie Súkupová

Lenka Thinová

Magdaléna Vičanová

Kateřina Pachnerová Brabcová

Hana Průšová

Iveta Smetanová

Dagmar Štěpánová

Jan Štika

Jana Svobodová

Lenka Thinová

Tomáš Trojek

Tomáš Urban

\section{Dny radiační ochrany sborník abstraktů}

Editor

Vydalo

Kontaktní adresa

Kontaktní osoba

Sazba

Vydáno

Počet stran

ISBN

DOI

Licence
Václav Štěpán

České vysoké učení technické v Praze

Katedra dozimetrie a aplikace ionizujícího záření,

Fakulta jaderná a fyzikálně inženýrská ČVUT v Praze,

Břehová 7, 11519 Praha 1

Lenka Thinová, +420607729178

Václav Štěpán a Vít Zýka

Praha, listopad 2021, první vydání

169

978-80-01-06915-8

https://doi.org/10.14311/DRO.2021.XLII

Dílo podléhá Creative Commons BY-NC-ND 4.0 
Vážené kolegyne, vážení kolegovia,

konferencia Dni radiačnej ochrany je už tradične miestom stretnutia českých a slovenských odborníkov, zástupcov štátnych organizácií, firiem aj študentov zaoberajúcich sa problematikou radiačnej ochrany.

Po minuloročnej neplánovanej prestávke, kedy sa konferencia $\mathrm{v}$ dôsledku protipandemických opatrení nemohla uskutočnit, sme sa rozhodli tento rok zorganizovat XLII. Dni radiačnej ochrany netradične online pomocou platformy Zoom a tiež netradične spoločne ako česko-slovenský organizačný tím.

$\mathrm{V}$ rámci konferencie si vypočujeme prednášky a miniprezentácie zaradené do ôsmich sekcií, v každej sekcii je na úvod zaradená prehladová prednáška. Novinkou je sútaž o najlepšiu prednášku pre študentov a mladých vedeckých pracovníkov do 35 rokov, ktorá tentoraz nahradila každoročnú sútaž o najlepší príspevok. Odborná komisia vyberie troch vítazov spomedzi 22 prihlásených sútažiacich.
V tomto ročníku konferencie ponúkame účastníkom možnost publikovat výsledky svojho výskumu ako články v špeciálnom čísle časopisu Radiation Protection Dosimetry a editorský tím sa teší na vaše zaujímavé príspevky.

Ako každoročne, aj tentoraz $\mathrm{v}$ stredu program vyvrcholí spoločenským večerom. Veríme, že si nájdete čas na sledovanie koncertu súboru Musica Florea, po ktorom bude nasledovat online ochutnávka vín. Niektorý z večerov si môžete spríjemnit sledovaním divadelného predstavenia študentov FJFI ČVUT Fyzikové, ktorého záznam bude $\mathrm{k}$ dispozícii pre účastníkov konferencie počas celého novembra.

$\mathrm{V}$ mene programového aj organizačného výboru Vám prajeme, aby ste si konferenciu a spoločenský večer užili aj v online forme, vypočuli si množstvo pútavých prednášok a dozvedeli sa novinky nielen vo svojom odbore. Pevne veríme, že nasledujúci ročník sa už uskutoční bez obmedzení a stretneme sa opät osobne.

Iveta Smetanová 
Tato práce je součástí projektu Centra pokročilých aplikovaných př́rodních věd (CAAS) pod číslem CZ.02.1.01/0.0/0.0/16_019/0000778. CAAS je spolufinancován Evropskou unií.

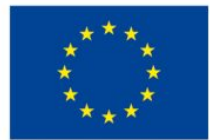

EVROPSKÁ UNIE

Evropské strukturální a investični fondy Operačni program Výzkum, vývoj a vzdělávání

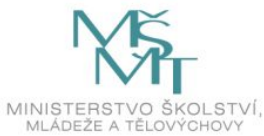




\section{Sponzoři}

\section{Hlavní sponzoři}

Canberra-Packard, s.r.o. www.cpce.net

\section{Canberra} Packard

VF, a.s.

www.vf.cz

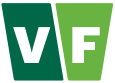

VF NUCLEAR

\section{Sponzoři}

EMPOS spol.s r.o.
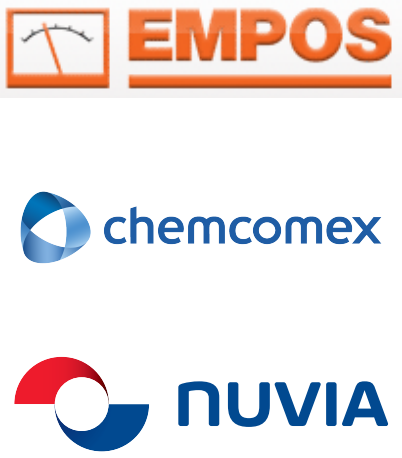

JAVYS a.s.

www.javys.sk

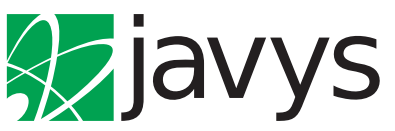

Slovenské elektrárne a.s. 


\section{Obsah}

Úvodní slovo . . . . . . . . . . . . . . . . . . . . . . . . 1

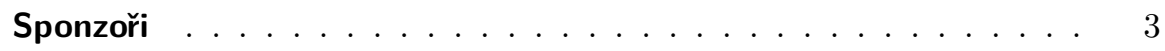

\section{Pondělí}

\section{Dozimetrie zevního a vnitřního ozáření - 1}

Evolution of Computational ICRP/ICRU phantoms Marie Zankl . . . . . . . . . . . . . . . . . . . . . . . . . . . 19

Studium odezvy dozimetrů prostředí vzhledem k novým operačním veličinám Zina Čemusová, Daniela Ekendahl, Libor Judas, Michaela Kapuciánová, Petr Kuča, Zdeněk Vykydal . . . . . . . . 20

Studium odezvy osobních dozimetrů vzhledem k novým operačním veličinám

Daniela Ekendahl, Michaela Kapuciánová, Dana Kurková, Libor Judas, Zdeněk Vykydal, Zina Čemusová . . . . . . . . . . . 21

Caveats of plutonium internal dosimetry: from biokinetics to dose estimates

Martin Šefl, Maia Avtandilashvili, Sergei Y. Tolmachev . . . . . 22

YAP:Ce scintillator application for wound injury counting Pavel Fojtík, Vendula Rovenská ................ 23

Monitoring of the radiation doses around the mini labyrinth experimental workspace at STU Štefan Čerba, Branislav Vrban, Jakub Luley, Vladimír Nečas, Karel Katovský, Ondřej Štastný, Filova Vendula, Gloginjić Marko, Erich Marko, Mravik Željko, Perović Srdjan . . . . . . . . . . . 24

Optimalizácia ochranného tienenia synchrotrónového urýchlovača protónov ProTom na zvýšenie energie protónov z 250 na $330 \mathrm{MeV}$ Andrea Šagátová, Marko Fülöp, Milan Jurčo, Ivo Pajdhauser, Pavol Ragan, Ružička Ján, Lubica Foltínová 
Vertikální dozimetrické měření elektrického výboje indukovaného vysokonapětovým generátorem

Dagmar Štěpánová, Jan Mikeš, Václav Štěpán, Michal Krbal,

Ondřej Ploc

Stanovení kalibračních a korekčních koeficientů křemíkových detektorů

Liulin a AIRDOS na základě porovnání dat z letových výšek

s pixelovými detektory Timepix

Marek Sommer, Dagmar Štépánová, Martin Kákona,

Olena Velychko, Iva Ambrožová, Ondřej Ploc . . . . . . . . . . . .

SPACEDOS - an open-source PIN diode dosimeter for applications in Space

M. Kákona, I. Ambrožová, K. O. Inozemtsev, O. Ploc,

R. V. Tolochek, L. Sihver, O. Velychko, J. Chroust, H. Kitamura,

S. Kodaira, M. Dobynde, V. A. Shurshakov ............ 28

Model na odhad radiačnej dávky pre pilotované lety do Slnečnej sústavy

Dominika Švecová, Pavol Bobík

New approach for fast triage of irradiated individuals

Lenka Andrejsová, Zuzana Šinkorová, Jana Čižková,

Alžběta Filipová, Marcela Jeličová, Anna Lierová

The usability of measuring membrane mitochondrial potencial by flow cytometry for studies in biodosimetry

Zuzana Šinkorová, Alžběta Filipová, Anna Lierová, Jana Čižková,

Lenka Andrejsová, Marcela Milanová

\section{Miniprezentace}

Ex vivo experimental model in biodosimetry

Lenka Andrejsová, Alžběta Filipová, Jana Čížková, Zuzana Šinkorová . . . . . . . . . . . . . . . . . . .

Radiační homogenita výplni při 3D tisku fantomu

Tomáš Vrba

OSL sensitivity of quartz extracted from fired bricks for retrospective dosimetry

Dan Reimitz, Ivan Hupka, Daniela Ekendahl

Kalibrace detektorů Airdos-C s různými krystaly (NaITl, CRY19) pro detekci vysokoenergetických jevů v atmosféře

Olena Velychko, Martin Kákona, Iva Ambrožová, Ondřej Ploc . . 36

Srovnání očních dozimetrů

Jiři Martinčík, Tomáš Čechák, Jana Tamášová, Lenka Siková, Zdenka Balogová, Iva Bártová 


\section{Metrologie, měření, přístrojová technika a její aplikace - 2}

Development, optimization, and calibration of an active electromagnetic calorimeter for pulsed radiation spectrometry Vojtěch Stránský, Valeria Istokskaia, Roberto Versaci, Lorenzo Giuffrida, Daniele Margarone, Veronika Olsovcova . . . 38

Plastic scintillator based 2D detector for quality assurance in photon radiotherapy - preliminary results Tereza Hanušová, Tomáš Vrba, Vladimír Linhart . . . . . . . . .

Modelovanie a optimalizácia modelu HPGe detektora GC0518 vo výpočtovom kóde MCNP5

Branislav Stríbrnský, Róbert Hinca, Gabriel Farkas, Martin Petriska, Peter Mikula . . . . . . . . . . . . . . . . . 40

Meranie plošnej aktivity Cs-137 v pokryvných útvaroch vo vybranej oblasti Podunajskej nížiny

Erik Andrássy, Andrej Mojzeš, Ema Nogová, Gabriela Wallová

\section{Miniprezentace}

Studium základních dozimetrických vlastností detektorů z $\mathrm{NaCl}$ Marie Kubinová, Daniela Ekendahl . . . . . . . . . . . . . . . . . 42

Dlouhodobé dohasínání scintilátorů

Ladislav Viererbl, Antonín Kolros, Hana Assmann Vratislavská

Charakterizace OSL a TL dozimetrů na Mikrotronu MT25

Veronika Olsovcova, Iva Ambrožová, Anna Cimmino,

David Chvátil, Silvia Motta, Václav Olšanský, Vojtěch Stránský, Jaroslav Šolc, Roman Truneček, Andriy Velyhan . . . . . . . . . .

Katalog rentgenových spekter emitovaných rentgenkami pro elektronickou brachyterapii

Jana Šmoldasová, Jaroslav Šolc, Vladimír Sochor . . . . . . . . .

Automatic procedure for localisation and dosimetry of wounds with radioactive contamination

Tomáš Slavíček, Pavel Fojtík, Peter Rubovič . . . . . . . . . . . 46

Validace Monte Carlo modelu detektorů MiniPIX TPX3 s různými senzory

Daniela Doubravová, Jana Šmoldasová, Jaroslav S̆olc, Eliška Trojanová

Mapování radioaktivní kontaminace území Josef Vošahlik, Ladislav Němeček, Petr Otáhal . . . . . . . . . . . 48

Modelová kalibrace leteckého gama spektrometru pro vyhledávání radionuklidových zdrojů s využitím BLP Jaroslav Klusoň, Lenka Thinová ． . . . . . . . . . . . . . . 
Prostorové rozlišení a závislost odezvy na výšce letu při radiometrickém monitorování s využitím BLP Jaroslav Klusoň . . . . . . . . . . . . . . . . . . . . . . . . 50

Stanovování plošné distribuce uranu a thoria ve vzorcích pomocí rentgenové fluorescenční analýzy

Tomáš Trojek, Darina Trojková

Konfokální rentgenová fluorescenční analýza homogenních vrstev Kateřina Limburská, Tomáš Trojek . . . . . . . . . . . . . . . . . 52

Determination of a TASTRACK plastic track detector to neutrons from the $\mathrm{Pu}$-Be source

Branislav Vrban, Jakub Luley, Štefan Čerba, Vladimír Nečas . . . 53

On uncertainties in the manganese sulphate bath techniques Jakub Luley, Štefan Čerba, Branislav Vrban, Vladimír Nečas . . . 54 


\section{Úterý}

\section{Metrologie, měření, přístrojová technika a její aplikace - 3}

Charakterizace a dozimetrie směsných radiačních polí v širokém rozsahu pomocí pixelových detektorů Timepix a Timepix3 Carlos Granja . . . . . . . . . . . . . . . . . .

MILEA, urychlovačový hmotnostní spektrometr, je v Řeži Ivo Světlik, Kateřina Pachnerová Brabcová, Josef Tecl

Radiouhlíkové datování uhlíků v mateřské historické maltě Kateřina Pachnerová Brabcová, Vojtěch Valášek, Tomáš Krofta, Pavel Šimek, Václav Suchý, Pavel Kundrát, Petr Kozlovec, Kristýna Kotková, Anna Fialová, Jan Válek, Ivo Světlik

Zpřesnění radiouhlíkového datování slonoviny

Vojtěch Valášek, Kateřina Pachnerová Brabcová, Ivo Světlik,

Jitka Kufnerová ． . . . . . . . . . . . . . . . .

Aplikácia primárnych metód na báze LSC pri štandardizácii rádionuklidov

Ivana Bonková, Jarmila Slučiak, Matej Krivošík

Měření promptní gama z nepružného rozptylu AmBe neutronů v $\mathrm{D}_{2} \mathrm{O}$ sféře

Tomáš Czakoj, Michal Koštál, Jan Šimon, Zdeněk Matěj,

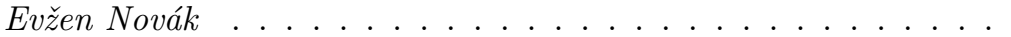

Monte Carlo simulace sběru iontů polonia v elektrickém poli pro účely diagnostiky zařízení měřicího objemovou aktivitu radonu Martin Kaschner, Michal Marčišovský, Pavel Staněk, Peter Švihra, Vladimír Kafka _. . . . . . . . . . . . . . . 61

Úhlová a energetická kalibrace křemíkových stripových detektorů Marek Sommer, Martina Lužová, Michal Marčišovský, Mária Marčišovská, Ondřej Ploc, Pavel Brož, Pavel Krist, Petr Suchánek, S. Kodaira, Václav Vrba

Spektrometrie vysokoenergetického fotonového záření na Lomnickém štítě detektorem RT56

Jakub Šlegl, Ronald Langer, Igor Strhárský, Jaroslav Chum, Iva Ambrožová, Tomáš Brunclík, Petr Mašek, Ondřej Ploc

Měření Regener-Pfotzerova maxima za použití více typů detektorů ionizujícího záření a nového telemetrického systému Jakub Kákona, Martin Kákona, Iva Ambrožová, Marek Sommer, Martin Povišer, Martina Lužová, Ondřej Ploc 
Komplexné riešenie spojeného výskumu v oblasti radiačnej ochrany, havarijnej pripravenosti, odozvy a obnovy Tatiana D̆úranová . . . . . . . . . . . . . . . . . . .

Šíření radioaktivních aerosolových částic v prostředí tréninkového polygonu SÚJCHBO

Petr Otáhal, Jakub Ondráček, Josef Vošahlík, Eliska Fialova, Hana Sýbková, Josef Holeček, Michaela Kozlovská, Eva Zemanová

Simulace dat pro výcvik terénních (pozemních i leteckých) skupin Jan Helebrant, Jelena Burianová, Petr Kuča . . . . . . . . . . .

Comparison of the release of large-scale components and fragments of auxiliary equipment of V1 NPP

Matej Forgáč, Branislav Vrban, Vladimír Nečas

Odhad radiační situace uvnitř a v blízkém okolí hlavního výrobního

bloku jaderné elektrárny po havárii reaktoru typu VVER-1000

Tomáš Urban, Jaroslav Klusoň

ESTE CBRN - modelovanie radiačnej situácie po aplikácii špinavej bomby

Ludovít Lipták, Mária Marčišovská, Peter Čarný, Eva Fojcíková

\section{Miniprezentace}

Stanovení transferových koeficientů pro dlouhodobější předpověd úrovně radiační kontaminace zemědělské krajiny

Jan Procházka, Kateřina Křváková, Iva Šímová, Jan Škrkal, Petr Rulík

Nakládání s radioaktivními odpady, vyřazování jaderných zařízení z provozu -5

Projekt demontáže hlavných zariadení primárneho okruhu JE V1 v Jaslovských Bohuniciach Tibor Rapant

Proces vyradovania JE A1 a spracovanie RAO v JAVYS, a.s.

Dušan Krásny

Standardization of the database structures for data and information used in nuclear-decommissioning projects

Dušan Daniška, Branislav Vrban, Vladimír Nečas

Comparison of the background gamma-ray spectrum from soil obtained by direct measurement and by calculation using MCNP6 with $\mathrm{NaI}(\mathrm{Tl})$ scintillation detector

Dávid Bednár, Martin Lištjak, Vladimír Nečas 


\section{Miniprezentace}

Príjem a distribúcia Sr-90 u rajčiaka jedlého ošetreného arbuskulárnymi mykoríznymi hubami

Silvia Dulanská, Igor Gomola, Lubomír Mátel, Klára Gébeová . 76 Bioplynová technologie - slibný způsob nakládání s rostlinnou

biomasou kontaminovanou radionuklidy

Jan Škrkal, Miroslav Kajan, Věra Záhorová ....... . 77 


\section{Středa}

\section{Radon a přírodní zdroje ionizujícího záření - 6}

Radón - náš neviditelný spoločník Monika Müllerová ...................... . 78

Analýza vplyvu zakrivenia dýchacích ciest na vyhodnotenie radónového rizika a jeho dôsledky I.

Radoslav Böhm, Karol Holý, Martin Bulko

Analýza vplyvu zakrivenia dýchacích ciest na vyhodnotenie radónového rizika a jeho dôsledky II.

Radoslav Böhm, Karol Holý, Martin Bulko

Monitorovanie radónu vo vybraných materských školách na Slovensku Monika Müllerová, Karol Holý, Patrícia Kureková, Iveta Smetanová

Zhodnotenie výsledkov pilotného radónoveho prieskumu v Slovenskej republike

Alexandra Kušnyerová, Alžbeta Ďurecová, Magdaléna Vičanová, Veronika Durdyová, Andrea Čipáková, Kamila Kleinová, Vladimír Trebichalský

„Radon-prone areas“ na území Slovenska predikované na základe preškálovaných máp radónového potenciálu Alžbeta Brandýsová, Jozef Masarik, Karol Holý, Martin Bulko, Monika Müllerová . . . . . . . . . . . . . . . . . . . .

Emanácia radónu-222 z rôznych typov a druhov pôd

Terézia Eckertová, Karol Holý, Monika Müllerová, Ivan Sýkora, Jozef Masarik

Štúdium vplyvu vlhkosti a velkosti pôdnych zŕn na emanáciu radónu z pôd využitím nového mnohočasticového modelu Terézia Eckertová, Karol Holý, Radoslav Böhm

Posouzení dopadu výskytu Rn-222 v tělese odvalu a jeho blízkém okolí z hlediska radiační ochrany

David Strnad, Lenka Thinová, Václav Štěpán

Modelování uhlíkového a radiouhlíkového cyklu na Zemi

David John, Kundrát Pavel, Ivo Světlík,

Kateřina Pachnerová Brabcová

Radón vo vnútornom ovzduší vybraných budov v obci Vydrník

(Vikartovský zlom, Slovensko)

Iveta Smetanová, Andrej Mojzeš, Kristian Csicsay,

František Marko

Případ zvýšeného výskytu ${ }^{210}$ Po v pitné vodě

Růžena Šináglová, Ivana Ženatá 
Bulgarian instruments for space radiation dosimetry and main scientific results

A. Kozyrev, A. Malahov, B. Tomov, Tsvetan Dachev, A. Sanin,

A. Vostrukhin, D. Golovin, D.P. Häder, E.N. Yarmanova,

F. Fedosov, F. Spurny, G. Horneck, G. Reitz, H. Kitamura,

I. Chernykh, I. Mitrofanov, I. Nikolaev, J. Kubancak, J. Semkova,

K. Krastev, M. Jordanova, M. Lebert, M. Litvak, M. Mokrousov,

M.T. Schuster, N. Bankov, N. Grebennikova, O. Ploc,

O.A. Ivanova, P. Dimitrov, R. Koleva, S. Nikiforov, St. Malchev,

V. Petrov, V. Tretyakov, V.A. Shurshakov, V.V. Benghin,

Y. Uchihori, Yu. Matviichuk ................. 92

Vliv pandemie COVID-19 na dozimetrii posádek letadel v Česku a na

Slovensku

Ondřej Ploc, Iva Ambrožová, Ivan Kovář, Martin Kákona,

Ján Kubančák, Martina Lužová, Marek Sommer,

Dagmar Štěpánová, Karel Turek, Olena Velychko . . . . . . . . . 93

Mnohokomponentné analýzy pôdy a atmosféry a ich aplikácie

Karol Holý, Monika Müllerová, Markus Helej, Terézia Eckertová,

Martin Bulko, Ivan Sýkora, Ivan Kontul, Jozef Masarik,

Radoslav Böhm

\section{Miniprezentace}

Review of important space weather events observed at the Lomnický štít high mountain observatory

Ján Kubančák, Igor Strhársky, Dagmar Štěpánová,

Iva Ambrožová, Ondřej Ploc, Pavol Bobik, Ronald Langer,

Šimon Mackovjak

Modelování dávkového prŕḱkonu gama uvnitř kalibrační základny pro terénní spektrometry

Kamila Johnová, Jaroslav Kluson̆

Speciální př́ipady měření za účelem stanovování efektivních dávek

pracovníků na pracovištích s materiálem se zvýšeným obsahem př́rodního radionuklidu

Eliška Fialová, Ivana Ženatá, Petr Otáhal, Jiř̌ Sejkora,

Václav Trantina, Dominika Kožešníková 


\section{Čtvrtek}

\section{Rentgenová diagnostika, radioterapie a nukleární medicína - 7}

Out-of-field doses in pediatric photon and proton radiotherapy Summary of the EURADOS WG9 activity

Željka Knežević

Dávky mimo cílový objem při protonové terapii: Experiment

EURADOS WG9 - příprava Monte Carlo simulací a první výsledky Jan Štika, Marie Davídková, Iva Ambrožová, Anna Jelinek Michaelidesova, Jaroslav Klusoň

Specifika radioterapie elektronovým svazkem v Nemocnici České

Budějovice a. s.

Eva Stýblová, Petra Jiřiková, Zuzana Freitinger-Skalická ... . . 101

Porovnanie $250 \mathrm{MeV}$ protónového cyklotrónu so synchrotrónom pri rádioterapii očnej šošovky

Andrea Šagátová, Igor Gomola, Marko Fülöp, Pavol Ragan, Lubica Foltínová

Radiační ochrana pacientů a personálu a prevence vzniku radiačních mimořádných událostí s aplikací na Oddělení nukleární medicíny Nemocnice České Budějovice, a.s.

Zuzana Freitinger-Skalická, Kristína Daňová, Vojtěch Kratochvíl, Ladislav Šabata . . . . . . . . . . . . . . . . . . . . . . . . . . . . 103

Diagnostické referenčné úrovne v skríningovej mamografii na Slovensku

Dušan Šalát, Denisa Nikodemova . . . . . . . . . . . . . . . . . . 105

Prehlad počtu vykonaných vyšetrení v jednotlivých rádiodiagnostických modalitách na Slovensku, v rokoch 2019-2020 Anita Zubáková, Karol Böhm, Dušan Šalát, Denisa Nikodemová 106

Príspevok k medzinárodnej diskusii o revízii a zjednodušení systému radiačnej ochrany Denisa Nikodemova, Dušan Šalát . . . . . . . . . . . . . . . . . . 108

Optimalizácia vyšetrovacích CT protokolov u obéznych pacientov pomocou zostrojeného antropomorfného fantómu Zdenka Balogová, Lucie Súkupová

Nevyhnutnost spätnej väzby pri sledovaní dávky žiarenia obdržanej pacientom pri lekárskych expozíciách.

Martina Horváthová, Zuzana Bárdyová, Igor Gomola

Faktory spôsobujúce bias pri hodnotení efektívnej dávky z výpočtovej tomografie srdca a koronárnych ciev Zuzana Bárdyová, Martina Horváthová, Igor Gomola ..... 112 


\section{Miniprezentace}

3D zobrazovanie pomocou CBCT (cone-beam počítačová tomografia), $\mathrm{v}$ stomatológii

Anita Zubáková, Denisa Nikodemová, Igor Gomola, Andrej Galbavý

Vliv kovových implantátů na kvalitu CT obrazů a na automatickou modulaci proudu: fantomová studie Hana Linhartová, Petr Libus

Voxelový Monte Carlo model antropomorfního fantomu torza trupu „Elvis“

Jana Šmoldasová, Jaroslav Šolc, Vladimír Sochor

Odhad externího ozáření personálu a rodinných příslušníku pacientů po radionuklidové terapii pomocí $\mathrm{Lu}-177$

Andrej Vondrák, Jana Hudzietzová, Marko Fülöp, Jozef Sabol, Peter Nemček

\section{Všeobecné aspekty radiační ochrany a vzdělávání - 8}

Je český radiologický fyzik evropským radiologickým fyzikem?

Irena Koniarová

Pregraduální a postgraduální vzdělávaní radiologických asistentů

v České republice a v rámci EU

Zuzana Freitinger-Skalická, Štěpán Kavan, Renata Havránková

Súčasné trendy v radiačnej ochrane intervenčných rádiológov

Darina Budošová, Martina Horváthová, Zuzana Bárdyová

Etické aspekty radiologické ochrany ve vnímání radiologických asistentů

Friedo Zölzer, Zuzana Freitinger Skalická, Zuzana Lotterová . . 122

Gamaspektrometrické měření obsahu radionuklidů po imitaci výbuchu špinavé bomby

Hana Sýbková, Michaela Kozlovská, Petr Otáhal

Stínící vlastnosti kompozitního nanovlákenného materiálu, vyrobeného metodou elektrostatického zvlákňování

Michaela Kozlovská, Eva Kuželová Koštáková, Jan Grégr,

Petr Otáhal

Monitoring trícia vo vodách za rok 2020

Natália Žabková, Anna Ondrušková

\section{Miniprezentace}

Testování vybraných metod pro dekontaminaci velkoplošných povrchů zamořených radioaktivními látkami Josef Holeček, Hana Sýbková, Petr Otáhal, Eva Zemanová . . . 127 
Stanovení poměru fixované a nefixované kontaminace radioaktivní látkou Eva Zemanová, Eliska Fialova, Josef Holeček, Petr Otáhal . . . . 128 Velkost dávky ionizujúceho žiarenia obdržanej pri lekárskom ožiarení a implementácia tejto informácie do diagnostického popisu vyšetrenia Zuzana Bárdyová, Martina Horváthová, Vladimír Neuschl, Igor Gomola . . . . . . . . . . . . . . . . . . . . . . . . . . 129

Precise experimental determination of attenuation coefficient and its simulation Jiřı Burian, Štefan Čerba, Marko Erich, Vendula Filová, Marko Gloginjić, Karel Katovský, Jakub Luley, Željko Mravik, Vladimír Nečas, Srdjan Petrović, Ondřej Štastný, Branislav Vrban 


\section{Pátek}

\section{Biologické účinky a zdravotní hlediska - 9}

About translational radiooncology - past, present, future Antje Dietrich . . . . . . . . . . . . . . . . . . . . . . 132

Dávka je len jedna dimenzia biologického účinku Dušan Šalát, Denisa Nikodemová . . . . . . . . . . . . . . . . . 133

Biologická účinnost a dozimetrie alfa zářičů v buněčných experimentech Lukáš Ondrák, Pavel Kundrát, Marek Sommer, Martin Vlk, Václav Štěpán, Marie Davídková ． . . . . . . . . . . . . . . . . . 134

Od makroskopického transportu záření ke struktuře stopy na mikroskopické úrovni

Pavel Kundrát, Giorgio Baiocco, Andrea Ottolenghi, Werner Friedland . . . . . . . . . . . . . . . . . 136

Rakovina plic, radon a kouření Ladislav Tomášek . . . . . . . . . . . . . . . . . . . . . 137

Odškodňování nemocí z povolání u horníků UD v ČR Ladislav Tomášek, Tomáš Müller . . . . . . . . . . . . . . . . . . 138

Vliv kultivačních podmínek na radiosensitivitu meduloblastomových buněk

Jana Klementová, Markéta Farníková, Irina Danilova, Šárka Jarošová, Martina Zíková, Marie Davídková

Dynamics of p53 in response to DNA damage caused by radiation

Irina Danilova, Martina Zíková, Jana Klementová, Marie Davídková

Záhada zvýšení buněčné odezvy indukované protony v př́tomnosti boru Irina Danilova, Marie Davídková, Zuzana Jamborová, Anna Jelinek Michaelidesova, Kateřina Pachnerová Brabcová, Pavel Kundrát, Václav Štěpán, Oldřich Zahradníček . . . . . . . . 141

Zvýšená biologická účinnost protonového ozařování buněk

$\mathrm{v}$ přítomnosti boru pravděpodobně není způsobena sekundárními neutrony

Anna Jelinek Michaelidesova, Oldřich Zahradníček,

Kateřina Pachnerová Brabcová, Irina Danilova, Jana Vachelová, Jan Vilimovský, Pavel Kundrát, Mirek David,

Vladimír Vondráček, Marie Davídková . . . . . . . . . . . . . . . . 142

Radiačné poškodenie plazmidovej DNA s bórovým nosičom Zuzana Jamborová, Marie Davídková, Anna Jelinek Michaelidesova, Egor Ukraintsev, Irina Danilova, Oldřich Zahradníček, Kateřina Pachnerová Brabcová . . . . . . . . 144 


\section{Miniprezentace}

Biological effects of low-dose radiation

Anna Lierová, Jan Novotný, Marcela Milanová, Jaroslav Storm, Lenka Andrejsová, Zuzana Šinkorová . . . . . . . . . . . . . . . . 145

Simulace poškození DNA při ozáření deuterony, heliem-3 a dalšími izotopy

Pavel Kundrát, Werner Friedland, Giorgio Baiocco, Andrea Ottolenghi . . . . . . . . . . . . . . . . . . . 146

Proteins of double-strand break and western blot analysis Jiři Toufar, Lucie Dobešová, Eva Pagáčová, Olga Kopečná, Iva Falková, Alena Bačíková, Michael Hausmann, Martin Falk . . 147 The relationship between PD-L1/PD-1/MHC-1/Her2/and other immune or oncogenic receptors Elham Parsimehr, Lucie Dobešová, Jiř́ Toufar, Eva Pagáčová, Olga Kopečná, Iva Falková, Alena Bačíková, Michael Hausmann, Martin Falk . . . . . . . . . . . . . . . . . . . . . . . . . . . . . . 148

Radiosensitizers in radiotherapy - gold nanoparticles Lucie Dobešová, Jiř́ Toufar, Eva Pagáčová, Olga Kopečná, Iva Falková, Alena Bačíková, Michael Hausmann, Martin Falk . . 150

Vývoj nových radioprotektivních látek na bázi malých molekulárních inhibitorů Alžběta Filipová, Jan Marek, Aleš Tichý, Radim Havelek, Martina Majorošová, Lenka Andrejsová, Tomáš Kučera, Lukáš Prchal, Lubica Múčková, Martina Řezáčová, Zuzana Šinkorová, Jaroslav Pejchal, Marcela Milanová, Jana Čížková

3D buněčný model pro radiobiologii: in ovo kultivace nádorových buněk Oldřich Zahradniček, Mária Hovořáková, Marie Davídková .. . 152

Rejstř́́k . . . . . . . . . . . . . . . . 153

\section{Stránky sponzorů}





\title{
Evolution of Computational ICRP/ICRU phantoms
}

\author{
Marie Zankl \\ Helholmtz Centrum München (GmBh) \\ zankl@helmholtz-muenchen.de
}

Efektivní a ekvivalentní dávka (externí ozáření) či jejich úvazky (pro interní ozáření) jsou klíčové veličiny radiační ochrany. Tyto veličiny jsou úzce spjaty s referenčními antropomorfními modely lidského těla. S rozvojem informačních technologií došlo i k vývoji těchto fan- tomů. V loňském roce vydala ICRP Publikace 143 a 145, které přinášejí již třetí generaci antropomorfních modelů. Přednáška shrnuje jak genezi tak benefity či naopak nevýhody jednotlivých generací fantomů. 


\title{
Studium odezvy dozimetrů prostředí vzhledem k novým operačním veličinám
}

\author{
Zina Čemusová, Daniela Ekendahl, Libor Judas, Michaela Kapuciánová, \\ Petr Kuča, Zdeněk Vykydal
}

Státní ústav radiační ochrany, v. v.i.

zina.cemusova@suro.cz

V loňském roce vydala ICRU novou publikaci (ICRU Report 95), která přináší revizi konceptu operačních veličin pro vnější ozáření. Byly definovány nové operační veličiny, které lépe odpovídají veličinám radiační ochrany, v nichž jsou vyjádřené limity pro regulaci ozáření. Tato změna bude mít nepochybně dopad na praktickou radiační ochranu. Stávající přístroje navržené pro měření původních operačních veličin je proto třeba otestovat a zjistit, zda a za jakých podmínek budou použitelné pro měření nových veličin. Tato práce byla zaměřena na vybrané aktivní i pasivní dozimetry používané pro monitorování dávek v prostředí v rámci Radiační monitorovací sítě ČR, př́ípadně pro účely havarijní připravenosti. Tyto dozimetry jsou optimalizovány pro měřní prostorového dávkového ekvivalentu, $H^{*}(10)$. V rámci provedeného experimentu jsme sledovali jejich potenciál pro měření nové operační veličiny - prostorové dávky, $\mathrm{H}^{*}$. Jejich odezva byla sledována pro spektra fotonů v rozpětí energií odpovídajících většině př́padi̊ monitorování prostředí v rámci radiační monitorovací sítě a pro vybraná spektra neutronů, a to jak pro účely měření $H^{*}(10)$, tak i pro měření $\mathrm{H}^{*}$. Odezvy dozimetrů ve vztahu k původní a nové veličině vykázaly systematický rozdíl vyplývající z rozdílných konverzních koeficientů původních a nových veličin. Z výsledků je zřejmé, že v případě fotonových spekter vyšších energií bude pro měření $\mathrm{H}^{*}$ nutné dozimetry překalibrovat, př́padně alespoň zavést individuální korekční faktor aplikovaný na jejich současnou odezvu vyjádřenou ve veličině $H^{*}(10)$. Větší rozdíly z hlediska možnosti měření $\mathrm{H}^{*}$ byly pozorovány směrem $\mathrm{k}$ nižším energiím fotonového záření a souvisely s tím, jak byly jednotlivé dozimetry optimalizovány z hlediska energetické odezvy. U většiny dozimetrů je překalibrování možné pouze zásahem výrobce. $\mathrm{V}$ případě testovaného neutronového dozimetru - heliem plněného proporcionálního počítače LB 6411 nebyl zjištěn zásadní problém z hlediska možnosti měření $\mathrm{H}^{*}$. Jeho odezvová funkce jak pro $\mathrm{H}^{*}(10)$, tak i pro $\mathrm{H}^{*}$, odpovídala současným požadavkům na přesnost měření.

Tato práce byla podpořena $\mathrm{v}$ rámci projektu Bezpečnostního výzkumu MV ČR (VI20192022156). 


\section{Studium odezvy osobních dozimetrů vzhledem k novým operačním veličinám}

\section{Daniela Ekendahl, Michaela Kapuciánová, Dana Kurková, Libor Judas, Zdeněk Vykydal, Zina Čemusová}

Státní ústav radiační ochrany, v. v.i.

daniela.ekendahl@suro.cz

ICRU předložila nové operační veličiny pro externí ozáření, které mají přímou návaznost na antropomorfní model lidského těla a lépe tak aproximují efektivní dávku a ekvivalentní dávku, v kterých jsou vyjádřeny limity. Novými operačními veličinami pro osobní monitorování jsou osobní dávka, $\mathrm{Hp}$, osobní dávka v oční čočce, Dp lens, a osobní dávka v místní kůži, Dp local skin. Současné osobní dozimetry byly navrženy a optimalizovány pro měření veličiny osobní dávkový ekvivalent ve vhodné hloubce d v ICRU měkké tkáni relevantní typu osobního monitorování, $\mathrm{Hp}(\mathrm{d})$. Vzhledem k definičním a konceptuálním rozdílům mezi původními a novými operačními veličinami nemusí být současné osobní dozimetry ideální z hlediska měření nových operačních veličin. Z důvodu posouzení dopadu implementace nových operačních veličin na praktickou radiační ochranu byla provedena experimentální studie, v jejímž rámci byly studovány odezvové funkce vybraných osobních dozimetrů v závislosti na typu a energii záření, a to z hlediska měření původních $(\mathrm{Hp}(10)$ a $H p(0.07))$ i nových operačních veličin (Hp a Dp local skin).
Ze získaných výsledků vyplývá, že současné osobní dozimetry kalibrované a navržené pro měření veličiny $\mathrm{Hp}(10)$ budou významně nadhodnocovat novou veličinu $\mathrm{Hp}$, a to především v oblasti nižších energií fotonového záření. Vícesložkové pasivní osobní dozimetry budou vyžadovat nejen kalibraci ve veličině $\mathrm{Hp}$, ale i změnu jejich designu (filtrace) nebo změnu vyhodnocovacího algoritmu. $\mathrm{V}$ případě většiny aktivních dozimetrů je překalibrování pro novou veličinu Hp podmíněno zásahem výrobce. Alternativní dočasnou možností je odvození individuálních korekčních faktorů aplikovaných na naměřenou hodnotu $\mathrm{Hp}(10)$. Současné aktivní osobní dozimetry používané $\mathrm{v}$ nízkoenergetických fotonových polích mohou rovněž vyžadovat změnu designu pro možnost měření $\mathrm{Hp}$. V př́ípadě neutronových osobních dozimetrů, které mají složité odezvové funkce $\mathrm{v}$ závislosti na spektru neutronů, dojde přechodem na veličinu Hp v některých oblastech energií ke zlepšení přesnosti měření, v jiných energetických oblastech naopak ke zhoršení. Co se týče možnosti měřní Dp local skin, současné osobní dozimetry navržené pro měření $\mathrm{Hp}(0.07)$ nevyžadují zásadní změnu. 


\title{
Caveats of plutonium internal dosimetry: from biokinetics to dose estimates
}

\author{
Martin Šefl, Maia Avtandilashvili, Sergei Y. Tolmachev \\ United States Transuranium and Uranium Registries, Washington State \\ University \\ martin.sefl@wsu.edu
}

A system of biokinetic models developed by the International Commission on Radiological Protection, including human respiratory tract, human alimentary tract, and plutonium systemic models, describes the biokinetic behavior of inhaled plutonium in the human body. The integral of activity in a biokinetic compartment at a given time results in the number of disintegrations which occurred in this compartment. The number of disintegrations can be converted to energy released and, using specific absorbed fractions (SAF), to energy deposited in a target organ. SAF is the fraction of particle energy emitted in a source region deposited in a target region per mass of the target tissue. For ${ }^{239} \mathrm{Pu}$, alpha particles are the dominant radiation contributing to absorbed dose; therefore, calculation of the dose seems fairly simple: multiply the number of disintegrations in a source region, the total al- pha energy emitted per one disintegration, and SAF for each combination of source-target region and energy. However, associating the compartments of the biokinetic models with source regions defined for SAF may be confusing. For some organs, like the liver, the process is straightforward; for others, it is more complicated. For example, 59 compartments are needed to model plutonium inhalation, and there are 79 source regions (tissues) for which the SAFs are defined. The associations depend on the biokinetic model, and, unfortunately, the biokinetic models are not always accompanied by explicit instructions on how to link the biokinetic model compartments with the corresponding dosimetric source regions. A step-by-step guide on the dosimetry of plutonium inhalation is presented including instructions on how to assign biokinetic compartments to dosimetric source regions. 


\title{
YAP:Ce scintillator application for wound injury counting
}

\author{
Pavel Fojtík, Vendula Rovenská \\ Státní ústav radiační ochrany, v.v. i. \\ pavel.fojtik@suro.cz
}

\begin{abstract}
YAP:Ce scintillation probe was tested contaminated wound was tested to for use in a spectrometric measure- verify the capability of the scintillament that is necessary to assess the tor to be used for gamma-ray spectrointernal dose in case of wound in- metry counting of ${ }^{241} \mathrm{Am}$ in a wound juries involving radionuclide contam- injury. Scintillation probe equipped inant. A technique with metal fil- with YAP:Ce scintillator showed propters published in the past for the de- erties sufficient for the wound counting termination of a depth of plutonium- technique tested.
\end{abstract}




\title{
Monitoring of the radiation doses around the mini labyrinth experimental workspace at STU
}

\author{
Štefan Čerba ${ }^{1}$, Branislav Vrban ${ }^{1}$, Jakub Luley ${ }^{1}$, Vladimír Nečas ${ }^{1}$, \\ Karel Katovský ${ }^{2}$, Ondřej Štastný ${ }^{2}$, Filova Vendula ${ }^{2}$, Gloginjić Marko ${ }^{3}$, \\ Erich Marko ${ }^{3}$, Mravik Željko ${ }^{3}$, Perović Srdjan ${ }^{3}$ \\ ${ }^{1}$ INPE FEI STU BA \\ ${ }^{2}$ Vysoké učení technické v Brně \\ ${ }^{3}$ Vinča Institute of Nuclear Sciences \\ stefan.cerba@stuba.sk
}

Since World War II there has been a significant development of methods and approaches used in the calculation of radiation shielding. Over time, modelling and simulation of relevant effects shifted from an analytical modelling to methods based on the so-called primary principles and their stochastic nature. Even nowadays it is necessary to know the accuracy of available computation codes, used nuclear data and it is desirable to evaluate the influence of the user on the final calculated parameter. One of the most effective ways of gaining user experience and minimizing user effects on the results of calculation is international collaboration comprising the designing and constructing of relevant benchmark experiments, following simulation with state-of-the-art calculation tools, comparison of work group results and subsequent identification of the source of observed deviations from the experiment. Currently a new experimental workplace, the so called "Mini Labyrinth" is being developed at STU. It is a simple neutron and gamma shielding benchmark, inspired by the ALARM-CF-AIR-LAB-001 ICSBEP experiment. The latest V1 experimental setup consists of a PuBe neutron source, several NEUTRONSTOP C5 shielding blocks (polyethylene with $5 \%$ boron), $\mathrm{H}_{2} \mathrm{O}$ filled PLA tank, plastic source holder, and detectors placed inside the Mini Labyrinth and around the experimental workplace. This paper is indeed focused on the monitoring of the radiation doses around the workplace using the NUVIATEC NUDET detector and the Thermo Scientific RadEye personal dose meter, as well as on the comparison of the measured quantities with ones simulated by MONACO (as a part of SCALE 6.2.4 system) and MCNP 6. The influence of different cross-section libraries and propagation of cross-section uncertainties is studied through this shielding analysis. The achieved results are included and finally, some discussions on further needed development are also included. 


\title{
Optimalizácia ochranného tienenia synchrotrónového urýchlovača protónov ProTom na zvýšenie energie protónov z 250 na $330 \mathrm{MeV}$
}

\author{
Andrea Šagátová ${ }^{1}$, Marko Fülöp ${ }^{2}$, Milan Jurčo ${ }^{2}$, Ivo Pajdhauser ${ }^{3}$, \\ Pavol Ragan ${ }^{4}$, Ružička Ján ${ }^{5}$, Lubica Foltínová ${ }^{6}$ \\ ${ }^{1}$ Slovak University of Technology in Bratislava \\ ${ }^{2}$ Centrum vedecko-technických informácií Slovenskej republiky \\ ${ }^{3}$ Fakulta podnikového manažmentu Ekonomickej univerzity v Bratislave \\ ${ }^{4}$ ABRS s.r.o. \\ ${ }^{5}$ Fakulta matematiky, fyziky a informatiky Univerzity Komenského \\ ${ }^{6}$ Ekonomická univerzita v Bratislave \\ marko.fulop@gmail.com
}

Synchrotrónový urýchlovač protónov ProTom na $250 \mathrm{MeV}$ bol spustený do trvalej prevádzky v roku 2013 na rádioterapeutické aplikácie a fyzikálny výskum. V budove urýchlovača sa pod správou CVTI vykonávajú preberacie skúšky, ktoré v súčasnosti potvrdzujú parametre prevádzky urýchlovača aj účinnosti ochranných radiačných tienení z obdobia jeho predošlého prevádzkovania. Počítačovými simuláciami Monte Carlo kódom MCNPX sa posudzuje prípadná potrebná úprava ochranných tienení na možnost zvýšenia energie protónov z 250 na $330 \mathrm{MeV}$, ktorá by umožnila výskum progresívnej protónovej rádiografie.
Pri optimalizácii ochranného tienenia urýchlovača protónov ProTom sa simulujú radiačne polia neutrónov a gama žiarenia vznikajúce pri interakciách protónov vyvedeného zväzku s materiálom terčov alebo aj so železom (Fe) vo vybraných úsekoch urýchlovacieho okruhu, napríklad v úseku deflektora. Príspevok prezentuje optimalizáciu zvýšenia účinnosti lokálneho ochranného tienenia neutrónov, emitovaných v deflektore interakciami protónov s Fe, pomocou dodatočnej vrstvy $16 \mathrm{~cm}$ NEUTROSTOPU C-3, vrstvy $20 \mathrm{~cm}$ betónu alebo vrstvy $10 \mathrm{~cm}$ hrubej železnej platne. 


\title{
Vertikální dozimetrické měření elektrického výboje indukovaného vysokonapětovým generátorem
}

\author{
Dagmar Štěpánová ${ }^{1}$, Jan Mikeš ${ }^{2}$, Václav Štěpán ${ }^{1}$, Michal Krbal $^{3}$, \\ Ondřej Ploc ${ }^{1}$ \\ ${ }^{1}$ Oddělení dozimetrie záření, Ústav jaderné fyziky AV ČR, v. v. i. \\ ${ }^{2}$ Fakulta elektrotechnická, ČVUT v Praze \\ ${ }^{3}$ Fakulta elektrotechniky a komunikačních technologií, VUT v Brně
} stepanova@ujf.cas.cz

Příspěvek se zabývá měřením ionizujícího záření emitovaného ve vertikálním poli elektrického výboje vzniklého mezi hrotem a uzemněnou rovinnou deskou u generátoru atmosférického impulzu 1,2/50 us, a to ve vzájemné vzdálenosti elektrod $1 \mathrm{~m}$. Podstatně rozšiřuje předchozí studii zabývající se částicovou emisí v planparalelní rovině s uzemněnou deskou, kde byla potvrzena jak přítomnost fotonů, tak tepelných neutronů. Ověření probíhalo za stejného nastavení generátoru atmosférického impulzu 1,2/50 $\mu$ s, bylo provedeno 400 negativních výbojů při napětí $0,9 \mathrm{MV}$ a celkové dodané energii do výboje $80 \mathrm{~kJ}$.

$\mathrm{Z}$ důvodu eliminace možného vlivu elektromagnetického záření samotného generátoru byly použity pasivní detektory $\mathrm{CaSO}_{4}$ :Dy pro stanovení fotonového záření a LiF:Mg:Ti (MTS-6, MTS-7 a MTS-N) pro detekci fotonové a neutronové složky.

Bylo vytvořeno 6 měricích setů, kdy každý set obsahoval 10 až 20 pasivních detektorů od každého typu. Měřicí sety byly umístěny v 5 různých polohách axiálně s dráhou elektrického výboje, tj. na hrotu elektrody, zemnící elektrodě a ve výškách $0,25,0,5$ a $0,75 \mathrm{~m}$ na vertikální ose ve vzdálenosti $1 \mathrm{~m}$ od horizontální osy elektrického výboje. Referenční set s pasivními detektory pro stanovení dávky pozadí byl umístěn v okolní laboratoři.

$\mathrm{Na}$ základě experimentu byla potvrzena př́tomnost fotonů $\mathrm{v}$ radiačním poli elektrického výboje. Potvrdilo se i statisticky významné navýšení absorbované dávky pro fotonové záření na hrotu aktivní elektrody a ve vzdálenosti $0,5 \mathrm{~m}$ od zemnící elektrody. Nově bylo prokázáno statisticky významné navýšení absorbované dávky od fotonů pomocí MTS-6 i pro zbylá měřicí místa. Navýšení odezvy od tepelných neutronů nebylo statisticky významné. 


\section{Stanovení kalibračních a korekčních koeficientů křemíkových detektorů Liulin a AIRDOS na základě porovnání dat z letových výšek s pixelovými detektory Timepix}

\section{Marek Sommer, Dagmar Štěpánová, Martin Kákona, Olena Velychko, Iva Ambrožová, Ondřej Ploc}

Oddělení dozimetrie záření, Ústav jaderné fyziky AV ČR, v. v.i. sommer@ujf.cas.cz

Pro zjištování radiačních dávek na palubách letadel jsou používány algoritmy (naprríklad CARI-7 a EPCARD), které vznikly na základě Monte Carlo simulací kosmického záření $\mathrm{v}$ atmosféře Země. Tyto výpočty jsou ověrovány pomocí nezávislých měření, které jsou často prováděny křemíkovými detektory typu Liulin a AIRDOS.

Citlivý objem detektorů Liulin a AIRDOS je tvořený velkoplošnou křemíkovou diodou $\left(2 \mathrm{~cm}^{2}\right)$, která má relativně velkou elektrickou kapacitu a tím pádem i vysoký šum. Z toho důvodu mají oba typy detektorů vyšší detekční práh než pixelové detektory Timepix, které mají vyčítací chip rozdělený na pixely a z toho důvodu mají nižší elektrickou kapacitu a jsou schopné měřit částice, které deponují velmi malé množství energie (přibližně $5 \mathrm{keV}$ ). Další výhodou detektorů Timepix je jejich vysoké energetické rozlišení. Každý pixel funguje nezávisle jako samostatná dioda a má 11810 kanálů. Detektory Liulin a AIRDOS rozdělují celý měřící rozsah na 256 kanálů, což výrazně omezuje jejich rozlišovací schopnost v porovnání s detektorem Timepix.

Obě vlastnosti, nižší detekční práh a větší rozlišovací schopnost Timepix detektorů, jsou využity pro stanovení kalibračních koeficientů detektorů Liulin a AIRDOS. Spektra deponovaných energií naměřená detektorem Timepix na palubě letadla jsou definovaně posunata a rozšířena tak, aby se co nejvíce shodovala se spektry z detektorů Liulin a AIRDOS. Tímto postupem je určen detekční práh detektorů Liulin a AIRDOS a také jejich šŕřka kanálu. Koeficient detečního prahu je použit pro odhad dávky, která nebyla registrována a pro stanovení korekčního koeficientu na tuto dávku.

Stanovené kalibrační a korekční koeficienty detektorů Liulin a AIRDOS jsou aplikovány na historická letecká data a porovnávány s výpočetním algoritmem CARI-7. Cúlem této práce je zpřesnit výpočet dávky měřené pomocí křemíkových detektorů Liulin a AIRDOS. 


\title{
SPACEDOS - an open-source PIN diode dosimeter for applications in Space
}

\author{
M. Kákona ${ }^{1}$, I. Ambrožová ${ }^{1}$, K. O. Inozemtsev ${ }^{2}$, O. Ploc ${ }^{1}$, R. V. Tolochek ${ }^{2}$, \\ L. Sihver ${ }^{1}$, O. Velychko ${ }^{1}$, J. Chroust ${ }^{3}$, H. Kitamura ${ }^{4}$, S. Kodaira ${ }^{4}$, \\ M. Dobynde ${ }^{2}$, V. A. Shurshakov ${ }^{2}$ \\ ${ }^{1}$ Nuclear Physics Institute of the Czech Academy of Sciences \\ ${ }^{2}$ Russian Academy of Sciences, Institute of Medical and Biological Problems \\ ${ }^{3}$ Universal Scientific Technologies Ltd. \\ ${ }^{4}$ National Institutes for Quantum and Radiological Science and Technology
} martin.kakona@odz.ujf.cas.cz

A new open-source dosimeter - Spacedos - for measurement of cosmic radiation onboard spacecraft and small satellites has been developed. Its main advantages are that it is small, lightweight with low power consumption. It can be adjusted for specific applications, e.g. used in pressurized cabins of spacecraft or in vacuum environment in CubeSats or larger satellites. The open-source design enables better portability and reproduction of results than other similar detectors.

The detector has already successfully performed measurements onboard the ISS. The obtained results will be discussed and compared with those measured with other detectors such as thermoluminescent and plastic nuclear track etched detectors, placed in the same location as Spacedos. 


\title{
Model na odhad radiačnej dávky pre pilotované lety do Slnečnej sústavy
}

\author{
Dominika Švecová ${ }^{1}$, Pavol Bobík ${ }^{2}$ \\ ${ }^{1}$ Univerzita Pavla Jozefa Šafárika \\ 2 Slovenská akadémia vied \\ dominika.svecova1@student.upjs.sk
}

Predstavujeme metodický a štrukturovaný model na odhad radiačnej dávky pre pilotované lety do slnečného systému. Model je založený na 1D modeli modulácie kozmického žiarenia a jednoduchého modelu pre interakcie ionizujúceho žiarenia s ludským telom. Model bol porovnávaný s misiou Mars Science Laboratory, presnejšie s dátami získanými prístrojom Radiation Assessment Detector (RAD) pri lete na Mars v rokoch 2011-2012. Výsledky nášho modelu a merania RAD sa zhodovali na akceptovatelnej úrovni. 


\section{New approach for fast triage of irradiated individuals}

\section{Lenka Andrejsová, Zuzana Šinkorová, Jana Čížková, Alžběta Filipová, Marcela Jeličová, Anna Lierová}

University of Defence, Faculty of Military Health Sciences, Hradec Kralove, Czech Republic

lenka.andrejsova@unob.cz

The objective of our study was to design biodosimetric methodology efficient for a practical usage for the population exposed to radiation emergencies. We focused on new approaches enabling rapid triage of irradiated individuals into five categories in accordance with METREPOL system (Fliender and col., 2007).

In our work, we used experimental animal model of minipigs for homogeneous total body gamma irradiation (TBI) by $0-4.2$ Gy. First the lethal dose $\mathrm{LD}_{50 / 30}$ was determined on 2.3-2.4 Gy after TBI. According to changes in haematological parameters occurring in the peripheral blood, the animals were divided into five categories H0 (non-irradiated), H1 $(\leq 0,4)$, H2 (0.6-1.2 Gy), H3 (1.4-2.0 Gy) and $\mathrm{H} 4$ ( $\geq 2,2 \mathrm{~Gy})$ differing each other in the prognosis of acute radiation sickness development and the treatment suggestion. Then the indicators of nuclear DNA damage (histone H2AX phosphorylation $\gamma \mathrm{H} 2 \mathrm{AX}$ ), induction of cell apoptosis (caspase 3 activation) and changes in relative and absolute cell counts of $\mathrm{T}$ and $\mathrm{B}$ lymphocytes in peripheral blood $(\mathrm{PB})$ were monitored by flow cytometry in all individuals.
Based on our results the value borders of interested parameters for each category were set and basic parameters suitable for triage into one of five categories were chosen. Early triage is based on monitoring changes on DNA $(\gamma \mathrm{H} 2 \mathrm{AX}) 1$ hour after TBI. Fast triage combines data of apoptosis induction (caspase 3 test) and changes in absolute counts and relative representation of PB lymphocytes 4 hours and 8 hours after TBI. Confirmation triage is based on data obtained by fast triage together with changes occurring in PB lymphocytes 48 hours after TBI.

So, based on experimental we have shown that minipigs represent a convenient large animal model for in vivo studies on PB leukocyte cell sensitivity with possible implications in practical biodosimetry. Our results were verified by the blind study which included ten total body irradiated animals by unknown dose. Eight of these animals were successfully classified into right category, the other two were classified into higher (more serious) category.

Acknowledgement: Supported by projects of the Ministry of Defence of the Czech Republic (long-term organization development plan Medical As- 
pects of Weapons of Mass Destruction of the Faculty of Military Health Science, University of Defence in Brno) and Ministry of Interior Affairs of the CR (project VH20172020010). 


\title{
The usability of measuring membrane mitochondrial potencial by flow cytometry for studies in biodosimetry
}

\author{
Zuzana Šinkorová, Alžběta Filipová, Anna Lierová, Jana Čížková, \\ Lenka Andrejsová, Marcela Milanová
}

Fakulta vojenského zdravotnictví, Univerzita obrany, Hradec Králové

lenka.andrejsova@unob.cz, zuzana.sinkorova@unob.cz

The purpose of our study was to evaluate membrane mitochondrial potentical measured by flow cytometry in vitro in two cell lines (MOLT-4, RAMOS) and immunophenotypised peripheral blood lymphocytes after gamma irradiation.

The usability of the JC-1 dye was tested on the cell lines and peripheral blood lymphocytes after gamma irradiation in in vitro study for future practical biodosimetric evaluation.

The cell lines derived from different precursor cells and pig lymphocytes are good tool for monitoring of the progress of radiation induced apoptosis, which brings view on the seriousness of injury of cells. We used JC-1 dye by flow cytometry method for determination of changes of mitochondrial mem- brane potential of MOLT-4, RAMOS cells and lymphocytes to monitor their mitochondrial health. We evaluated the stage of injury these cells by irradiated versus no-irradiated ratio (IVNIR) of relative proportions of polarized cells with red aggregates of JC-1. We observed decreasing of IVNIR with obtained dose $(0.5 ; 1 ; 2 ; 4 ; 6 ; 8$ and $10 \mathrm{~Gy})$ and the cultivation time after irradiation $(4 ; 8$ and $24 \mathrm{~h}$ ) in MOLT-4 cells and in the whole peripheral blood lymphocytes and their populations ( $\mathrm{T}$ cytotoxic cells, CD4 T lymphocytes, NK cells and B cells). The most sensitive to irradiation were CD4 T lymphocytes in the porcine peripheral blood by JC1dye test. We revealed radioresistency of RAMOS cells. 


\title{
Ex vivo experimental model in biodosimetry
}

\section{Lenka Andrejsová, Alžběta Filipová, Jana Čížková, Zuzana Šinkorová}

Fakulta vojenského zdravotnictví, Univerzita obrany, Hradec Králové

\author{
lenka.andrejsova@unob.cz
}

Individual biological dosimetry and acute radiation syndrome assessment are based on clinical signs development during first hours after exposition. Acute symptoms are useful for first fast triage of large numbers of irradiated people, nevertheless they are not characteristic for irradiation and they can be influenced also by other injuries as burns or lacerations. Laboratory methods allowing more precise retrospective dose assessment are conventionally based on analyses of peripheral white blood cells which sensitively response to irradiation by physiological cell death (apoptosis) induction. Our new ex vivo experimental approach eliminates a count of blood samplings and it could significantly decrease a sampling load of each irradiated person. In our study we used ex vivo experimental biodosimetric approach of apoptosis detection. Ex vivo model comes from standardly in vivo irradiated animal experimental model. Six rats per group were in vivo wholebody exposed to homogeneous ionizing irradiation of $0-7$ Gy $\left({ }^{60} \mathrm{Co}\right.$ gamma source). Peripheral blood of each animal was collected 1 hour or 4 hours after exposition. Non-irradiated animals were served as controls. Peripheral blood mononuclear cells (PBMC) were isolated, washed in culture medium Dozimetrie zevního a vnitřního ozáření and finally cultivated $(0-3-5-7-23$ hours) under ex vivo conditions $\left(37^{\circ} \mathrm{C}\right.$, $\left.5 \% \mathrm{CO}_{2}\right)$. Afterwards, cells were immunophenotyped by the antibody cocktail (CD45RA_PE, CD8_V450, CD3_APC, CD161_biotin_streptavidine_V500), stained by an apoptosis detection kit (Annexin V_FITC kit) and analysed data were acquired on a CyAn ADP flow cytometer.

All lymphocyte subsets incline to radiation-induced apoptosis with a dose-dependent manner, nevertheless with a different intensity and at a different time. B-lymphocytes went through apoptosis 6 hours after irradiation. Tlymphocytes decline not started until 8 hours and NK cell apoptosis was noted at 24 hours.

The pool of peripheral white blood cells consists from morphologic and functionally different populations in which lymphocytes prove the highest radiosensitivity differing a lot among functionally different lymphocyte subpopulations ( $\mathrm{T}$ - and B-lymphocytes, natural killer cells) and their subsets. Ex vivo detection of apoptosis inducing lymphocyte subsets distinguishes between high (lethal) and low (sublethal) dose of irradiation already 6 hours after exposition and allows back estimate of absorbed dose. 


\title{
Radiační homogenita výplni při 3D tisku fantomu
}

\author{
Tomáš Vrba \\ FJFI ČVUT v Praze \\ tomas.vrba@fjfi.cvut.cz
}

Trojdimenzionální tisk je bezesporu stupů, jak tento nedostatek odstranit, efektivní způsob, jak v dnešní době vy- je několik. Tisk s neúplnou výplní, tedy tvářet antropomorfní fantomy pro ra- když vnitřní objem je záměrně vyplněn diační ochranu a radiologickou fyziku. tiskovým materiálem se vzduchovými Jednou z nevýhod 3D tisku fantomu komůrkami, je jedním z možných řešení. jsou radiační vlastnosti tiskových ma- Článek se snaží prověřit použitelnost teriálů (strun), které zpravidla nemají úplně stejné zeslabení jako tkáně lidského těla, které mají nahrazovat. Přítohoto př́stupu experimenty s různými vzory výplní. 


\title{
OSL sensitivity of quartz extracted from fired bricks for retrospective dosimetry
}

\author{
Dan Reimitz, Ivan Hupka, Daniela Ekendahl \\ SÚRO, v.v.i. \\ dan.reimitz@suro.cz
}

Optically stimulated luminescence of quartz extracted from fired materials is used for retrospective dosimetry for about 40 years. Quartz sensitivity to thermoluminescence (TL) and optically stimulated luminescence (OSL) can vary over few orders of magnitude. This discrepancies in sensitivity for the quartz originating from different parts of the world is still not yet fully understood.

We have extracted quartz from bricks produced by three different companies in Czech Republic. Quartz was extracted from fired bricks, as well as before firing. Significant changes in quartz sensitivity were observed after firing process. Sensitivity can both increase or decrease, depending mainly on the maximum temperature achieved during firing process. For same samples, the sensitivity was greatly increased after firing (7 times higher signal after same dose before firing) and after repeated irradiation exposures, but for same samples, the sensitivity remained low. 


\title{
Kalibrace detektorů Airdos-C s různými krystaly (NalTI, CRY19) pro detekci vysokoenergetických jevů $v$ atmosféře
}

\author{
Olena Velychko, Martin Kákona, Iva Ambrožová, Ondřej Ploc \\ Ústav jaderné fyziky AV ČR, v.v.i. \\ velychko@ujf.cas.cz
}

Ve výšce letu současných civilních letadel (nejčastěji 9-11 km nadmořské výšky) je intenzita kosmického záření i při příznivém geofyzikálním stavu atmosféry několikanásobně vyšší než u povrchu Země. Kvůli tomu cestující a posádka obdrží určitou dávku záření od pronikajícího kosmického záření. V důsledku různých jevů (slunečních událostí, bouřkové aktivity) navíc může dojít k několikanásobnému zvýšení dávky. Tudíž je třeba mít neustálou kontrolu těchto údajů na palubě letadla. Toto může být provedeno pomocí různých detektorů. Jedním z kritických parametrů pro detektory používané $\mathrm{k}$ dlouhodobému monitorování úrovně ozáření na palubách letadel je relativně malá hmotnost a rozměry. Vývojem takových detektorů se zaobírá mj. skupina autorů tohoto výzkumu. $\mathrm{V}$ prezentaci jsou popsány a charakterizovány detektory Airdos-C s různými scintilačními krystaly (NaI(Tl), CRY19). Na rozdíl od detektorů založených na Si diodě, které se běžně $\mathrm{k}$ dlouhodobému měření na letadlech používají, mohou být použity pro detekci vysokoenergetického záření gama generovaného v bouřkách.
Pro správnou interpretaci naměřených dat je důležité nejprve ověřit odezvu detektorů ve známých polích zářní a provést energetickou kalibraci. Kalibrace detektorů byla provedena pomocí několika radionuklidových zdrojů a výsledky byly analyzovány s použitím metod matematické statistiky. Byly vyvinuty metody umožňující získat hraniční meze pro každý energetický kanál a určit procento detekovaných částic ležících v daném intervalu energií. Pro určení polohy píku se použily metody matematické statistiky pro upresnění modální hodnoty. Dále byl vypočten čas potřebný pro získání průměrného počtu částic v kanálu s předem zadanou hodnotou intervalu spolehlivosti a bylo určeno rozpětí energie, kde tyto detektory mohou spolehlivě fungovat. Pomocí vyvinutého matematického aparátu s cílem řízení kvality obdržených výsledků byly vypočteny odhady maxim energie pro různé radionuklidy, které následně byly ověřeny měřením. Detektory byly také použity na palubě letadla při letu za dobře definovaných podmínek. 


\title{
Srovnání očních dozimetrů
}

\author{
Jiří Martinčík ${ }^{1}$, Tomáš Čechák ${ }^{1}$, Jana Tamášová ${ }^{2}$, Lenka Siková ${ }^{2}$, \\ Zdenka Balogová, Iva Bártová \\ ${ }^{1}$ FJFI ČVUT v Praze \\ 2 Nemocnice Na Homolce \\ jiri.martincik@fjfi.cvut.cz
}

Oční čočka se odlišuje od jiných tkání dvěma radiobiologickými charakteristikami, vyšší radiosenzitivitou a dlouhou dobou latence vzniku katarakty. V ČR jsou v současné době $\mathrm{k}$ dispozici dva systémy monitorování oční čočky, které jsou připraveny ke komerčnímu využití. NUVIA Dosimetry s.r.o. provozuje filmové dozimetry a VF Nuclear a.s. nabízí TL dozimetry.

V rámci experimentu byly testovány oba systémy s cílem oveřit, jak dozimetry splňují požadavky kladené na osobní dozimetry. Dlouhodobým záměrem těchto testů je snaha o nalezení nějaké korelace mezi údajem osobního dozimetru a očního dozimetru ve stan- dardních geometriích. Proto bylo vytipováno několik modelových geometriích stanovených na základě typických pozic intervenčních radiologů a intervenčních kardiologů. Měření proběhlo na hybridním multioborovém sále Nemocnice Na Homolce. Měření bylo doplněno simulací in-silico. K tomuto byl zvolen modelový stochastický př́stup, využívající simulaci transportu záření metodou Monte Carlo.

$\mathrm{V}$ práci je podrobně rozebrána metodika experimentu, geometrie ozáření a srovnání výsledných dávek získaných jednotlivými typy použitých dozimetrů. 


\title{
Development, optimization, and calibration of an active electromagnetic calorimeter for pulsed radiation spectrometry
}

\author{
Vojtěch Stránský, Valeria Istokskaia, Roberto Versaci, Lorenzo Giuffrida, \\ Daniele Margarone, Veronika Olsovcova \\ ELI Beamlines, Institute of Physics, CAS, Czech Republic \\ vojtech.stransky@eli-beams.eu
}

Spectrometry in radiation fields generated by high power lasers is challenging, since the radiation is created in ultra short pulses $\left(10^{-14}-10^{-12} \mathrm{~s}\right)$ and thus standard spectrometric methods cannot be applied. The electromagnetic calorimeter developed within this study is an active system that can be used for such spectrometry in the energy range from tens of $\mathrm{keV}$ to tens of $\mathrm{MeV}$; even for high repetition rate petawatt class laser systems $(10 \mathrm{~Hz})$. The calorimeter comprises of a set of scintillators that are wrapped in PTFE and placed into a 3D printed holder. Scintillation light is detected by a CMOS camera, the acquired dose-depth curve is then evaluated by a dedicated unfolding algorithm. In this paper, the calibration of the calorimeter using Cs-137 and Co-60 radioactive sources is presented. The results demonstrate the developed calorimeter is able to determine energy of impinging radiation with an uncertainty of approximately $10 \%$. 


\title{
Plastic scintillator based 2D detector for quality assurance in photon radiotherapy - preliminary results
}

\section{Tereza Hanušová, Tomáš Vrba, Vladimír Linhart}

Czech Technical University in Prague, Faculty of Nuclear Sciences and Physical Engineering

tereza.hanusova@fjfi.cvut.cz

\begin{abstract}
A proof-of-concept study of a new deA statistical technique based on setector based on a thin plastic scintillator monitored by a CCD camera designed for monitoring and characterization of Linac photon beams is presented. The response of the detector is compared to radiochromic film dosimetry using $6 \mathrm{MV}$ and $18 \mathrm{MV}$ radiotherapeutic beams. We have observed: (i) all instruments survive secondary radiation fields during Linac operation, (ii) it is possible to process measured data using statistical techniques and (iii) processed data from the CCD camera qualitatively correspond to film dosimetry results. lection of minimal value provides the clearest results. Quantitatively, CCD and film results can only be compared as $6 \mathrm{MV}$ to $18 \mathrm{MV}$ response rates. We have observed that the rates from the CCD data are systematically higher than the rates from film dosimetry. Differences between these two rates are not very high, namely $1.9-2.4 \times$ the combined standard deviation. The work was supported from European Regional Development FundProject "Center of Advanced Applied Sciences" No. CZ.02.1.01/0.0/0.0/16$019 / 0000778$.
\end{abstract}




\title{
Modelovanie a optimalizácia modelu HPGe detektora GC0518 vo výpočtovom kóde MCNP5
}

\author{
Branislav Stríbrnský, Róbert Hinca, Gabriel Farkas, Martin Petriska, \\ Peter Mikula
}

Slovenská technická univerzita v Bratislave

branislav.stribrnsky@stuba.sk

Cielom našej práce bolo zostave- sú dostupné. Následne sme pristúpili nie MCNP modelu HPGe detektora GC0518 firmy Mirion a jeho následná optimalizácia. V prvom kroku boli vykonané merania s bodovými kalibračnými zdrojmi v zadefinovaných pozíciách vzhladom na detektor, ako aj merania s Marinelliho nádobami. Tiež boli vykonané merania za účelom určenia, resp. overenia hrúbky mŕtvej vrstvy germánia na povrchu kryštálu a za účelom overenia tvaru a pozície holderu kryštálu. Cielom týchto meraní bolo tiež overit možnosti určovania týchto parametrov výlučne na základe merania, čo môže byt užitočné pri modelovaní detektorov, pre ktoré tieto dáta nie $\mathrm{k}$ zostaveniu samotného MCNP modelu s použitím výpočtového kódu MCNP5. Prvotný model detektora bol založený výlučne na nominálnych parametroch detektora uvedených v dokumentácii výrobcu. Relatívne rozdiely vo vypočítaných a v nameraných účinnostiach však boli na úrovni 10-15\%. Preto sme pristúpili k optimalizácii týchto parametrov v rámci neistôt uvedených v dokumentácii dodanej výrobcom, ale tiež na základe našich meraní. Takto sa nám podarilo vytvorit model detektora, kde sa relatívne rozdiely medzi vypočítanými a nameranými účinnostami pohybujú na úrovni jednotiek percent. 


\title{
Meranie plošnej aktivity Cs-137 v pokryvných útvaroch vo vybranej oblasti Podunajskej ní̌iny
}

\author{
Erik Andrássy ${ }^{1}$, Andrej Mojzeš ${ }^{1}$, Ema Nogová ${ }^{2}$, Gabriela Wallová ${ }^{3}$ \\ ${ }^{1}$ Katedra inžinierskej geológie, hydrogeológie a aplikovanej geofyziky, \\ Prírodovedecká fakulta Univerzity Komenského \\ 2 Oddelenie gravimetrie a geodynamiky, Ústav vied o Zemi, Slovenská akadémia \\ vied \\ 3 Výskumný ústav vodného hospodárstva, Národné referenčné laboratórium pre \\ oblast vôd na Slovensku \\ andrassy4@uniba.sk
}

Metóda trajektóriovej analýzy zaznamenala prechod rádioaktívneho mračna, emitovaného z havarovanej jadrovej elektrárne V. I. Lenina v Černobyle o polnoci dňa 27. apríla 1986 , ktorý v noci z 29. apríla na 30. apríla 1986 prenikol cez severnú hranicu na územie Československej socialistickej republiky a pokračoval južným smerom. Prúd vzduchu zapríčinil kontamináciu atmosféry a neskôr aj geosféry nad strednou častou Československa. V roku 2009 Štátny geologický ústav Dionýza Štúra bezplatne sprístupnil pre verejnost mapovú aplikáciu plošnej aktivity Cs-137. Mapová aplikácia dokumentuje stav kontaminácie územia Slovenskej republiky rádioaktívnym céziom. Na tvorbu mapy boli použité všetky sprístupnené výsledky stanovenej plošnej aktivity Cs-137 z celého územia Slovenskej republiky za roky 19902003. Mapová aplikácia je dostupná na priloženom linku: https://www.geology.sk/geoinfoportal/mapovy-portal/geofyzikalne-mapy/mapa-radioaktivity-cezia/.

Predkladaný príspevok sa venuje výsledkom opakovaných meraní plošnej aktivity Cs-137 v anomálnych oblastiach na Podunajskej nížine v okolí obcí Velké Úlany a Čierna Voda v okrese Galanta. Práve v týchto miestach boli v 90. rokoch detegované najvyššie aktivity rádioaktívneho izotopu Cs-137 na Podunajskej nížine, ako dôsledok jeho vypadávania z ovzdušia počas zrážkovej činnosti. Výsledky naznačujú velkú mieru poklesu aktivity, pričom sa tvar anomálie do určitej miery zachováva.

Príspevok vznikol vdaka finančnej podpore $\mathrm{v}$ rámci riešenia projektu APVV-16-0146 „Multidisciplinárny výskum geofyzikálno-štruktúrnych parametrov a environmentálneho vplyvu zlomov Západných Karpát". 


\title{
Studium základních dozimetrických vlastností detektorů z $\mathrm{NaCl}$
}

\author{
Marie Kubínová, Daniela Ekendahl \\ Státní ústav radiační ochrany, v. v.i. \\ marie.kubinova@outlook.com
}

Chlorid sodný $(\mathrm{NaCl})$ je běžně dostupná sloučenina s celou řadou praktického využití. Z dozimetrického hlediska se jedná o látku, která vykazuje opticky stimulovanou luminiscenci (OSL). Tato vlastnost byla u soli v drríve publikované literatuře zkoumána především z pohledu retrospektivní dozimetrie při využití jednotlivých zrnek soli. $\mathrm{S}$ ohledem na takto zjištěné dozimetrické vlastnosti a cenu a dostupnost tohoto materiálu přišly úvahy o vytvoření peletek a aplikace $\mathrm{v}$ havarijní dozimetrii. Tato práce se zabývá základními dozimetrickými vlastnostmi vyrobených peletek ze soli analytické kvality a dvou běžně dostupných kuchyňských solí. Byla sledována dávková závislost i hodnoty minimální detekovatelné dávky, které u takto zhotovených peletek dosahují hodnot $\mathrm{v}$ řádu desítky $\mu \mathrm{Gy}$. Tato i další pozorované vlastnosti pak ukazují výhody plynoucí ze změny formy soli - výsledky pro samotná zrnka soli nejsou tak př́znivé. Dále se práce zaměřuje na postup měření a vyhodnocení peletek s ohledem na možné praktické aplikace. Důraz byl kladen na možnost využití SingleAliquot Regeneration Dose (SAR) protokolu. Z pohledu vyhodnocení peletek se pak ukázalo jako vhodné používat již předem ozářené a vyčtené peletky. Závěrem práce stanovuje doporučení pro měření a vyhodnocení peletek. 


\title{
Dlouhodobé dohasínání scintilátorů
}

\section{Ladislav Viererbl, Antonín Kolros, Hana Assmann Vratislavská}

\author{
Centrum výzkumu Řež \\ ladislav.viererbl@cvrez.cz
}

Příspěvek se zabývá průběhem dlouhodobého dohasínání (afterglow) některých typů scintilátorů používaných k detekci ionizujícího záření. Po interakci scintilátoru s částicí ionizujícího záření dojde k excitaci scintilátoru a následnému vyzáření světelného impulzu. Hlavní světelný impulz mívá dobu dosvitu řádově nanosekundy až mikrosekundy a využívá se k detekci ionizujícího záření s využitím detektoru světla (fotonásobiče, fotodiody). Po hlavním světelném impulzu následuje vyzařování dalších složek s delší dobou dosvitu. Toto dohasínání je z hlediska detekce ionizujícího záření většinou nežádoucí. Rozsah zde studovaných dob dosvitu byl desítky sekund až dny.

Ke studiu dohasínání bylo použito sedm typů scintilátorů: $\mathrm{CaF}_{2}(\mathrm{Eu})$, $\mathrm{CsI}(\mathrm{Tl}), \quad \mathrm{CdWO}_{4}, \quad \mathrm{LiI}(\mathrm{Eu}), \quad \mathrm{BGO}$, $\mathrm{NaI}(\mathrm{Tl})$ a plastický scintilátor. K excitaci scintilátorů byla použita UV lampa, což umožňuje dostatečnou excitaci scintilátoru bez použití silného zdroje pronikavého záření. Po desetiminutovém ozáření byl scintilátor vložen do detekční jednotky s fotonásobičem zapojeném v proudovém režimu. Anodový proud fotonásobičem byl měřen pikoampérmetrem počínaje zhruba 30 s po ukončení ozařování a konče minimálně dva dny po ozáření.

Jednotlivé vzorky scintilátorů měly z důvodu komerční dostupnosti různé rozměry a hmotnost. Jednotlivé typy scintilátorů se také liší světelným výtěžkem, spektrálním složením emitovaných fotonů apod. Aby tedy bylo možné aspoň částečně porovnat jednotlivé scintilátory $\mathrm{z}$ hlediska křivky dohasínání, byl změřený časový průběh proudu normalizován na hodnotu proudu odpovídajícího záření pozadí (dávkový příkon cca $150 \mathrm{nSv} / \mathrm{h}$ ) měřenou před ozářením daného scintilátoru. Analýza křivek dohasínání ukázala, že ve všech př́ipadech se jedná o superpozici několika složek s různou dobou dosvitu. Nejlepší výsledky z hlediska dohasínání vykázaly scintilátory $\mathrm{CaF}_{2}(\mathrm{Eu})$ a plastický scintilátor - měly relativně malé hodnoty proudu $30 \mathrm{~s}$ po ozáření (zhruba 10 násobek pozadí) a po třech hodinách hodnota klesla na úroveň pozadí. Naopak např́klad scintilátor BGO dosahoval $30 \mathrm{~s}$ po ozáření 100 násobku pozadí a ani po několika dnech se hodnota nepřibližila hodnotě pozadí. 


\title{
Charakterizace OSL a TL dozimetrů na Mikrotronu MT25
}

\author{
Veronika Olsovcova ${ }^{1}$, Iva Ambrožová ${ }^{2}$, Anna Cimmino ${ }^{1}$, David Chvátil ${ }^{2}$, \\ Silvia Motta ${ }^{3,1}$, Václav Olšanský ${ }^{2}$, Vojtěch Stránský ${ }^{1}$, Jaroslav Šolc ${ }^{4}$, \\ Roman Truneček ${ }^{1}$, Andriy Velyhan ${ }^{1}$ \\ ${ }^{1}$ ELI Beamlines, Fyzikální ústav AV ČR, v. v.i. \\ 2 Ústav jaderné fyziky AV ČR, v. v.i. \\ 3 Politecnico di Milano \\ 4 Český metrologický institut \\ veronika.olsovcova@eli-beams.eu
}

Pražský Mikrotron MT25 je kruhový urychlovač elektronů s Kapitzovým rezonátorem, který urychluje elektrony až na energii $25 \mathrm{MeV}$, se standardní opakovací frekvencí $423 \mathrm{~Hz}$, délkou pulsu $3,5 \mu$ s a středním maximálním proudem $30 \mu \mathrm{A}$.

Studie prováděné se svazky záření generovanými konvenčním způsobem, jako je Mikrotron MT25, umožňují zkoumat odezvu dozimetrů ve známých a kontrolovatelných radiačních polích. Následně je možné vyvinout vhodné modely a předvídat jejich chování v komplexních radiačních polích, jako jsou ty, které jsou generovány laserovými urychlovači nebo terapeutickými zařízeními využívajícího efektu FLASH (dodání velmi vysokých dávek ve velmi krátkých pulsech).
V rámci práce na projektu 18HLT04 UHDpulse, zaměřeného na metrologii pro pokročilou radioterapii pomocí částicových svazků s vysokou dávkou v pulsu, byla na Mikrotronu MT25 studována odezva detektorů na bázi termoluminiscence (TL) a opticky stimulované luminiscence (OSL).

Studované detektory byly umístěny na plexisklovém fantomu a pro odstínění rozptýleného záření bylo nainstalováno stínění (olovo a železo). Dále byly použity GAFchromic ${ }^{\mathrm{TM}}$ filmy a detektory stop. Byla provedena dvě samostatná ozařování: $\mathrm{s} 8 \mathrm{~cm}$ silným polyethylenovým moderátorem umístněným před fantomem a bez moderátoru.

$\mathrm{V}$ př́spěvku budou presentovány výsledky teoretické studie a porovnání odezev různých detekčních systémů. 


\title{
Katalog rentgenových spekter emitovaných rentgenkami pro elektronickou brachyterapii
}

\author{
Jana Šmoldasová, Jaroslav Šolc, Vladimír Sochor \\ Český metrologický institut \\ jsmoldasova@cmi.cz
}

Elektronická brachyterapie (eBT) využívá pro léčení vybraných nádorových onemocnění fotonové záření emitované miniaturní rentgenkou. Z pohledu radiační bezpečnosti pacientů i lékařského personálu se jedná vhodnější metodu než běžná radionuklidová brachyterapie, protože rentgen lze jednoduše vypnout. Přestože v České republice takové zařízení stále není $\mathrm{k}$ dispozici, Český metrologický institut se účastní mezinárodního výzkumného projektu 18NRM02 PRISM-eBT ( „Primary standards and traceable measurement methods for X-ray emitting electronic brachytherapy devices“), jehož primárním cílem je podpořit přípravu standardů a procedur pro návaznost dozimetrických veličin v elektronické brachyterapii.

Jedním z vedlejších cílů je vytvoření katalogu eBT spekter. Katalog byl vytvořen pro spektra eBT rentgenek pěti hlavních výrobců: Zeiss - Intrabeam, Xoft - Axxent, Elekta - Esteya, Ariane Medical Systems - Papillon50 a WOLFMedizintechnik - ioRT-50. Obsahuje dostupná spektra fluence fotonů získaná od výrobců, z literatury, z Monte Carlo výpočtů nebo přímým měřením. Naměřená spektra jsou stanovena ve vzduchu a spektra z MC simulací typicky ve vodě ve vzdálenosti $1 \mathrm{~cm}$ od rentgenky.

Některé z těchto fluenčních spekter jsou použity pro definování a realizaci tzv. eBT ekvivalentních spekter. Tato spektra jsou v katalogu též uvedena a jedná se o fluenční spektra, která mají shodné parametry jako fluenční spektra eBT rentgenek ve zvolené vzdálenosti a materiálu (typicky ve vodě v hloubce $1 \mathrm{~cm}$ ), avšak budou realizována ve vzduchu v kalibračních laboratořích pomocí běžného rentgenu s wolframovou anodou za účelem kalibrace př́istrojů, typicky ionizačních komor, určených pro měření $\mathrm{v}$ radiačním poli příslušné $\mathrm{eBT}$ rentgenky.

Katalog je uveden na webových stránkách projektu (http://www.ebtempir.eu/). 


\title{
Automatic procedure for localisation and dosimetry of wounds with radioactive contamination
}

\author{
Tomáš Slavíček ${ }^{1}$, Pavel Fojtík ${ }^{2}$, Peter Rubovič ${ }^{2}$ \\ ${ }^{1}$ ÚTEF ČVUT v Praze \\ 2 Státní ústav radiační ochrany, v. v.i. \\ tomas.slavicek@cvut.cz
}

\begin{abstract}
Accidents involving radioactive materisituations, we are developing a meaals are one of the most dangerous accisurement system consisting of a robotic dents a living organism can be exposed to. Individuals and first responders are in the risk during the accidents or interventions, due to radioactive debris impact, due to the depleted uranium ammunition or a malevolent act against individuals. Moreover, radioactive contamination of wounds causes internal exposure of the body and standard decontamination procedures cannot be arm, array of various detectors and corresponding methodology, which allows to quantify timely the spatial distribution of contamination and the radiation dose for the adequate medical response. The aim of this publication is to present current status of the development and demonstrate first measurement results done with phantoms and radioactive traces.
\end{abstract}

applied. In order to deal with such 


\title{
Validace Monte Carlo modelu detektorů MiniPIX TPX3 s různými senzory
}

\author{
Daniela Doubravová ${ }^{1}$, Jana Šmoldasová ${ }^{2}$, Jaroslav Šolc $^{2}$, Eliška Trojanová ${ }^{1}$ \\ 1 ADVACAM s. r. o. \\ 2 Český metrologický institut \\ jsmoldasova@cmi.cz
}

Projekt TAČR „RaDron“ se zabývá vývojem miniaturního zařízení pro rychlou lokalizaci statického i pohybujícího se zdroje radioaktivního záření pomocí autonomního letového prostředku. Pro dosažení tohoto cíle byly využity také Monte Carlo výpočty v kódu MCNP, jejichž primárním účelem bylo nalezení optimálních hodnot parametrů detektoru MiniPIX TPX3 pro dosažení maximální detekční účinnosti zařízení. Správnost MC modelu detektoru byla potvrzena jeho validací provedenou porovnáním vybraných relevantních veličin s měřením.

Detekčním zařízením byla tzv. jednovrstvá nebo dvouvrstvá Comptonova kamera sestávající z detektoru MiniPIX TPX3 tvořeným senzory Si tlouštky $1 \mathrm{~mm}$, CdTe $1 \mathrm{~mm}$, CdTe $2 \mathrm{~mm}$ a jejich kombinací. Měření bylo provedeno se standardními bodovými radionuklidovými zdroji Ba-133, Cs-137, Am-241 a Eu-152, přičemž detektor byl od zdroje vzdálen $100 \mathrm{~mm}$. Veličinami, které byly porovnávány se simulací, byly píková detekční účinnost, průměrná absorbovaná energie na jeden foton, detekční účinnost událostí bez ko- incidence a detekční účinnost dvojných koincidencí se součtem energií v zadaném intervalu.

Monte Carlo model věrně vystihoval jak geometrii měření, tak zejména samotný detektor. Při výpočtech byl využit tzv. PTRAC soubor se zápisem jednotlivých událostí v senzoru, protože při následném zpracování bylo nutné stanovit deponované energie jednotlivými částicemi a vzdálenosti interakcí, pokud se jednalo o koincidence.

Rozdíly mezi měřením a výpočtem se pohybovaly typicky v rozmezí $\pm 10 \%$, což bylo považováno za přiměřenou shodu s ohledem na komplexnost porovnávaných dat. Validace potvrdila, že v případě měření hraje klíčovou roli správná energetická kalibrace detektoru a přesné měření času za účelem správného nalezení koincidenčních událostí.

Projekt FW01010317 RaDron - Lokalizace zdrojů ionizující radiace pomocí malých bezpilotních helikoptér s detektorem na principu Comptonovy kamery je spolufinancován se státní podporou Technologické agentury ČR v rámci programu TREND 2019. 


\title{
Mapování radioaktivní kontaminace území
}

\author{
Josef Vošahlík, Ladislav Němeček, Petr Otáhal \\ Státní ústav jaderné, chemické a biologické ochrany, v. v.i., Kamenná \\ vosahlik@sujchbo.cz
}

V rámci projektu MV ČR byla ve rychlé stanovení rozsahu a úrovně velkospolupráci s firmou Georadis, s.r.o., plošné kontaminace radionuklidy emiBrno provedena sada měření na zku- tující záření gama $\mathrm{v}$ městské zástavbě šebním polygonu (imitující městskou a pro vytyčení zón se zvýšenou radiací. infrastrukturu) vytvořeném $\mathrm{v}$ areálu Poster byl vypracován na základě SÚJCHBO, v.v.i. Kamenná. Měření výsledků řešení projektu MV ČR pomocí přenosného gama spektrome- č. VH20182021036 „Moderní metody tru GT-40, gama spektrometru D230A v podvěsu dronu a pojízdného spektrometru RT-58 bylo provedeno po explozi „šspinavé bomby“ s Tc-99m. V rámci experimentu byla zjištována možnost použití těchto moderních př́istrojů pro detekce a identifikace nebezpečných CBRN látek a materiálů, metody snížení jejich nebezpečnosti a dekontaminace; moderní prostředky ochrany osob". 


\title{
Modelová kalibrace leteckého gama spektrometru pro vyhledávání radionuklidových zdrojü s využitím BLP
}

\author{
Jaroslav Klusoň, Lenka Thinová \\ KDAIZ FJFI ČVUT v Praze \\ kluson@fjfi.cvut.cz
}

Byla provedena studie využitelnosti malého leteckého gama spektrometru neseného BLP pro vyhledávání radionuklidových zdrojů a odhadu jejich aktivity. Provedeny byly modelové výpočty kalibračních koeficientů pro spektrometr D230A fy Georadis (s dvěma detektory $\mathrm{NaI}(\mathrm{Tl}) 2 \times 2$ palce), radionuklidy ${ }^{241} \mathrm{Am},{ }^{57} \mathrm{Co},{ }^{137} \mathrm{Cs},{ }^{192} \mathrm{Ir},{ }^{60} \mathrm{Co}$ a ${ }^{152} \mathrm{Eu}$ a letové výšky $1,2,3,5,7,10$, 15,20 a 25 metrů. Výsledky byly porovnány s výsledky experimentálních měření pro zdroje ${ }^{137} \mathrm{Cs}$ a ${ }^{60} \mathrm{Co}$ pro vybrané výšky 1 až $10 \mathrm{~m}$ nad zdrojem na povrchu terénu. Detailní porovnání experimentálních a modelových spekter bylo provedeno pro měření ve výšce 1 metr. Modelován a diskutován je i možný značný vliv konstrukce a pouzdra zdroje, resp. i polohy/orientace zdroje (vzhledem k neizotropní emisi vlivem konstrukce zdroje) na odhad aktivity neznámého zdroje. Analyzován byl rovněž vliv př́rodního pozadí a jeho složek K, U, Th na MDA pro jednotlivé radionuklidy, resp. odhad požadavků na rozestupy letových linií při plánování trasy BLP pro zajištění záchytu zdroje za předpokladu jeho minimální aktivity. 


\title{
Prostorové rozlišení a závislost odezvy na výšce letu při radiometrickém monitorování s využitím BLP
}

\author{
Jaroslav Klusoň \\ KDAIZ FJFI ČVUT v Praze \\ kluson@fjfi.cvut.cz
}

Interpretace výsledků leteckého radiometrického monitorování terénu závisí mimo jiné na prostorovém rozlišení měření (tj. ploše, z které je průměrována hodnota měřené veličiny) a závislosti odezvy měřícího zařízení na výšce letu. Pro potřeby monitorování s využitím BLP byly orientační hodnoty těchto parametrů stanoveny stochastickými výpočty pro zvolené modelové podmínky. Výpočty byly provedeny pro homogenní distribuci terestriálních složek přírodního pozadí (K, U, Th) v nasycené povrchové vrstvě půdy a pro povrchovou kontaminaci radionuklidy s energiemi v rozsahu $0.3-3 \mathrm{MeV}$. Závislost na poloměru zdroje byla mode- lována v rozsahu 2-450 m a výšková závislost v rozsahu 1-30 m. Prostorové rozlišení je prezentováno ve formě relativní hodnoty kumulativního příspěvku $\mathrm{k}$ př́konu kermy ve vzduchu v závislosti na poloměru zdroje a pro jednotlivé výšky letu z uvedeného intervalu. Závislost na výšce letu je prezentována ve veličině př́íkonu kermy ve vzduchu v závislosti na objemové/plošné aktivitě zdroje nebo relativně $\mathrm{k}$ výšce 1 metr. Modelované závislosti slouží pro zpřesnění interpretce experimentálních dat nebo pro optimalizaci plánování tras monitorovacích letů podle zadaných cílů monitorování. 


\title{
Stanovování plošné distribuce uranu a thoria ve vzorcích pomocí rentgenové fluorescenční analýzy
}

\author{
Tomáš Trojek, Darina Trojková \\ FJFI, ČVUT v Praze \\ tomas.trojek@fjfi.cvut.cz
}

Ke stanovení koncentrací mnohých prvků, včetně uranu a thoria, v různých vzorcích je možné použít nedestruktivní analytickou metodu nazývanou rentgenová fluorescenční analýza (RFA), která je založena na stimulované emisi charakteristického záření vznikajícího ve vzorku po dopadu fotonového záření z vhodného zdroje (nejčastěji z rentgenky). Měření uranu a thoria nepatří sice $\mathrm{k}$ hlavním aplikacím metody RFA, ale takové analýzy jsou možné díky dostatečně vysoké energii charakteristického záření těchto těžkých prvků, které mají zároveň i vysoký účinný průřez pro fotoelektrický jev. Standartní RFA analýzy spočívají v měření vybraného místa na povrchu předmětu nebo vzorku a stanovení koncentrací přítomných prvků. Pro analýzu nehomogenních vzorků byla na Katedře dozimetrie a aplikace ionizujícího záření, FJFI, ČVUT v Praze sestavena aparatura pro RFA skenování, díky které je možné provést automaticky velký počet analýz na předem vybrané ploše a z naměřených dat zrekonstruovat plošné rozložení jednotlivých prvků. Díky vyměnitelnému zdroji budícího záření lze vzorky skenovat $\mathrm{v}$ makrorežimu s prostorovým rozlišením řádově milimetrů nebo lze dosáhnout rozlišení až 20 mikrometrů, pokud je jako zdroj budícího záření použita rentgenka s polykapilární fokusací svazku. V tomto př́spěvku jsou také zhodnoceny analytické možnosti obou přístupů, tedy makro- a mikro-skenování, především s ohledem na měření uranu a thoria v geologických vzorcích. Výsledky jasně demonstrují, pro jaká požadovaná prostorová rozlišení má ještě smysl provádět klasickou kolimaci svazku, a kdy je naopak již nutné použít finančně náročnějšś fokusaci rentgenového svazku pomocí rentgenové optiky. 


\title{
Konfokální rentgenová fluorescenční analýza homogenních vrstev
}

\author{
Kateřina Limburská, Tomáš Trojek
}

kackalimbur@gmail.com

Konfokální rentgenová fluorescenční analýza (RFA) je nedestruktivní metoda, která umožňuje stanovit hloubkovou distribuci prvků ve zkoumaném vzorku. Přesné stanovení hloubkových distribucí prvků z naměřených hloubkových profilů je velmi náročné a obecně platný postup nebyl dosud vypracován. Hlavním cílem práce bylo navrhnout a otestovat univerzální zjednodušený výpočetní postup, který by umožňoval vypočítat přibližný tvar hloubkových profilů pro vzorek tvořený z vrstev dané tlouštky a daného složení. K potvrzení navržené výpočetní metody byl použit standartní referenční materiál NIST 1412, kterým je homogenní sklo obsahující oxidy několika měřitelných prvků. V práci je porovnáván výsledný naměřený hloubkový profil skla a výpočet hloubkového profilu pro referenční materiál, které se téměř dokonale shodují. 


\title{
Determination of a TASTRACK plastic track detector to neutrons from the $\mathrm{Pu}$-Be source
}

\author{
Branislav Vrban, Jakub Luley, Štefan Čerba, Vladimír Nečas \\ Slovak University of Technology in Bratislava, Slovakia \\ branislav.vrban@stuba.sk
}

The solid-state nuclear track detectors (SSNTDs) are widely used in a variety of nuclear physics experiments and radiation protection. The paper presents the first results of the newly acquired TASLIMAGE neutron dosimetry system at the Slovak University of Technology in Bratislava. A comparison of experimental and calculated responses of a TASTRAK plastic nuclear track detector to neutron spectra of $\mathrm{Pu}-\mathrm{Be}$ source is presented. The doses determined by the TASLIMAGE system are compared to the ones measured by the NuDET-ENE neutron detector based on the use of a $\mathrm{ZnS}(\mathrm{Ag})$ scintillator covered with a thin film of ${ }^{6} \mathrm{LiF}$ thermal neutron converter accommodated inside the HDPE moderator. The first results are concluded and further research needs are identified. 


\title{
On uncertainties in the manganese sulphate bath techniques
}

\author{
Jakub Luley, Štefan Čerba, Branislav Vrban, Vladimír Nečas \\ Slovak University of Technology in Bratislava, Slovakia \\ jakub.luley@stuba.sk
}

The manganese sulphate bath is a globally recognized method for determining emission of neutrons from radionuclide sources. In combination with the measurement of neutron emission anisotropy this method is standardly used for primary standardization of dosimetry quantities of neutron radiation. To achieve results at the metrology level it is necessary to have all quantities which contribute to the overall uncertainty properly determine and contributing uncertainties minimized. Therefore, this paper is focused on the quantification of the possible sources of the uncertainties. The measurement system is characterized by external circuit and primarily used in continual mode. The system consists of the spherical shaped plexiglass bath vessel with a dry channel, where the neutron source is placed during measurement, and forced circuit with a special Marinelli beaker equipped by the $76 \times 76 \mathrm{~mm}$ cylindrical $\mathrm{NaI}(\mathrm{Tl})$ gamma detector. The circulation time of the manganese solution is also not negligi- ble during continual measurement of the activity. For validation purposes the specific activity measurement can be performed for samples extracted from the front and the back side of the Marinelli beaker. Sample measurements, which is also case of the static measurement, is performed by high purity germanium detector (HPGe). In previous analyses the final uncertainty of neutron emission rate was less than $1 \%$, which was considered as a target value. Nevertheless, the relative change from reference values was relatively high and out of this uncertainty. Calculated neutron emission rates were in the range of $\pm 10 \%$ according to used neutron source. This relative change raised questions about the accuracy of other contributed parameters, like volume of the vessel, concentration of $\mathrm{MnSO}_{4}$ measurement evaluation method or computational model. Therefore, the main part of this paper focuses on determination and reevaluation of these parameters with corresponding uncertainties. 


\title{
Charakterizace a dozimetrie směsných radiačních polí v širokém rozsahu pomocí pixelových detektorů Timepix a Timepix3
}

\author{
Carlos Granja \\ Advacam s. r. o., Praha, Česká republika \\ carlos.granja@advacam.com
}

Polohově-citlivé pixelové detektory Timepix a Timepix3 umožňují charakterizovat radiační pole $\mathrm{v}$ širokém rozsahu ve smyslu složení, intenzity, energie a směru. Precizní detektory spolu s pokročilými metodami spektrometrie a sledování jednotlivých částic mohou detekovat a rozpoznat komponenty směsných polí včetně lehkých a těžkých nabitých částic, záření $\mathrm{X}$ a zčásti i gama záření a neutronů. $V$ př́spěvku bude shrnutá používaná instrumentace
(ASIC chipy a polovodičové senzory $\mathrm{Si}, \mathrm{CdTe}, \mathrm{GaAs})$, readout elektronika a metody zpracování dat. Výsledky lze získat ve formě spektrálních a směrových toků částic, spektra LET a dávkových př́konů podle typu částic. Budou prezentovány výsledky měření v různých expozičních situacích (přírodní prostředí, okolí urychlovače částic, radioterapeutická ozařovna, vesmír nebo LEO orbita). 


\title{
MILEA, urychlovačový hmotnostní spektrometr, je v Řeži
}

\author{
Ivo Světlík, Kateřina Pachnerová Brabcová, Josef Tecl \\ ÚJF AV ČR, v.v.i. \\ brabcova@ujf.cas.cz
}

V Ústavu jaderné fyziky AV ČR v. v. i. je od roku 2004 provozována radiouhlíková datovací laboratoř CRL, a to ve spolupráci s Archeologickým ústavem $\mathrm{AV} \check{C} \mathrm{R}$ v.v.i. Původně byla pro stanovení aktivity ${ }^{14} \mathrm{C} \mathrm{k}$ disposici pouze radiometrická metoda založená na syntéze benzenu a následném měření ${ }^{14} \mathrm{C}$ pomocí kapalinové scintilační spektrometrie. Při tomto postupu se registrují přímo radioaktivní přeměny ${ }^{14} \mathrm{C}$, což vzhledem $\mathrm{k}$ dlouhému poločasu přeměny 5730 let, klade nárok na množství zpracovaného vzorku a délku analýzy. Od roku 2011 se proto laboratoř CRL soustředila na zavedení postupů př́ipravy mikrovzorků pro měření urychlovačovým hmotnostním spektrometrem (Accelerator Mass Spectrometry, AMS). Tím se snižuje množství potřebného vzorku, které činí pro radiometrickou metodu obvykle desítky gramů, ale v nepříznivých případech i stovky, na jednotky až stovky miligramů, při současném zlepšení přesnosti měření. Navíc se výrazně zkracuje doba měření, ze dnů na hodiny. Vzorky, které jsou radiometricky nedatovatelné, nebot by došlo ke zničení jejich významné části a tím i např́klad jejich historické hodnoty, jsou přístupné pro AMS analýzu, která je z tohoto hlediska téměř nedestruktivní. Ačkoliv naše laboratoř již mnoho let dokázala připravovat vzorky pro AMS, u samotných měření ${ }^{14} \mathrm{C}$ jsme se doposud museli spoléhat na zahraniční laboratoře.

$\mathrm{V}$ červenci tohoto roku se podařilo našemu ústavu díky účasti v projektu RAMSES nainstalovat a zprovoznit unikátní AMS systém MILEA, který byl vyvinut spoluprací švýcarské firmy Ionplus AG a univerzity ETH Zurich. MILEA je vybavena $300 \mathrm{kV}$ tandetronovým urychlovačem $\mathrm{s}$ heliovým stripovacím plynem, dvěma elektrostatickými a třemi magnetickými deflektory, optickými prvky a pokročilou ionizační komorou. To umožňuje významně potlačit izobarické interference a měřit radionuklidy s dlouhým poločasem přeměny, které se vyskytují ve velmi nízkých izotopových poměrech. $\mathrm{V}$ případě ${ }^{14} \mathrm{C}$ a v uhlíkové isotopické směsi převládajícího izotopu ${ }^{12} \mathrm{C}$ je tento poměr menší než 10-15.

$\mathrm{V}$ nové budově s urychlovačovou halou se budují také nové prostory pro radiouhlíkovou laboratoř $\mathrm{CRL}$ určené ke zpracování mikrovzorků pro AMS měření. Kromě zdvojení některého stávajícího vybavení, které zvýší kapacitu laboratoře, je chystána také grafitizační linka s malým objemem, která umožní př́pravu i velmi malých vzorků o hmotnostech stovek mikrogramů. 


\title{
Radiouhlíkové datování uhlíků v mateřské historické maltě
}

\author{
Kateřina Pachnerová Brabcová ${ }^{1}$, Vojtěch Valášek ${ }^{1}$, Tomáš Krofta ${ }^{1}$, \\ Pavel Šimek ${ }^{1}$, Václav Suchý ${ }^{1}$, Pavel Kundrát ${ }^{1}$, Petr Kozlovec ${ }^{2}$, \\ Kristýna Kotková $^{2}$, Anna Fialová ${ }^{2}$, Jan Válek $^{2}$, Ivo Světlík ${ }^{1}$ \\ ${ }^{1}$ ÚJF AV ČR, v. v. i. \\ ${ }^{2}$ UTAM AV ČR, v.v.i. \\ brabcova@ujf.cas.cz
}

Radiouhlíkové datování historických malt je komplikováno procesy probíhajícími při zrání malt, z nichž některé mohou vzorek zestařovat a jiné omlazovat. $\mathrm{V}$ obecných př́padech je složité tyto rušivé procesy potlačit natolik, abychom došli ke správnému výsledku. Alternativními vzorky $\mathrm{k}$ datování jsou organické zbytky včleněné do mateřské malty, jako jsou např́klad dřevěné uhlíky, semena, mikrobiota, dřevo nebo kosti. Tyto vzorky jsou často vnímány jako ne zcela spolehlivé, nebot jejich stáří nemusí odpovídat stáří malty. V literatuře je často zmiňován tak zvaný "problém starého dřeva“, kdy jsou pro vypalování malty použity velmi staré stromy, takže datování vzniklých uhlíků poskytuje zavádějící výsledek.

Tato práce zkoumá, jak je datování takových organických inkluzí, konkrétně dřevěných uhlíků, spolehlivé z hlediska datování mateřské malty. Pro studii byly vybrány české hrady nebo kostely, které vyhověly následujícím požadavkům: i) jejich věk je dokumentován $\mathrm{v}$ písemných pramenech a ideálně potvrzen bud jinou datovací metodou, nebo radiouhlíkovým datováním jiných vzorků než malt; ii) objekty mají dobře známou historii oprav a údržby; iii) nepocházejí z období po roku 1650, nebot to je z hlediska radiouhlíkového datování nepříznivé a vzorky poskytují díky kolísání aktivity ${ }^{14} \mathrm{C} \mathrm{v}$ přírodě několik intervalů výsledného stáří, z nichž nejstarší začíná po roce 1650 a nejmladší končí kolem roku 1950. Na pěti raně až pozdně středověkých objektech bylo navzorkováno celkem 192 uhlíků, přičemž jejich výskyt kolísal od 0,003 do 0,676 uhlíků na $\mathrm{m}^{2}$ plochy zdi.

Porovnání datovací interpretace výsledki̊ AMS analýz ${ }^{14} \mathrm{C}$ a známého stář́ archeologických objektů lokalit ukázalo, že problém starého dřeva není př́liš̌ rozšířený. 


\title{
Zpřesnění radiouhlíkového datování slonoviny
}

\section{Vojtěch Valášek, Kateřina Pachnerová Brabcová, Ivo Světlík, Jitka Kufnerová}

\author{
ÚJF AV ČR, v.v.i. \\ valasek@ujf.cas.cz
}

Obchod se slonovinou slona afrického je, až na některé výjimky, možný pouze u starožitných artefaktů s původem před rokem 1947. Tato skutečnost vyplývá z mezinárodní úmluvy CITES (Convention on International Trade in Endangered Species of Wild Fauna and Flora). Úmluva platí od roku 1989 a byla implementována do legislativ většiny zemí, včetně zemí Evropské unie. Cílem je zamezit vyhynutí afrických slonů, jejichž počet povážlivě klesá, a to prokazatelně hlavně v důsledku pytláctví.

Radiouhlíkové datování představuje důležitý nástroj v boji proti nezákonnému obchodu se slonovinou. Obecně radiouhlíková metoda využivá měření aktivity ${ }^{14} \mathrm{C}$, která ve vzorku přetrvává po jeho vyloučení z uhlíkového koloběhu, např́klad usmrcením organismu. Ze známého průběhu aktivity ${ }^{14} \mathrm{C}$ v minulosti, tedy kalibrační křivky, lze pak stanovit stáří vzorku. V důsledku atmosférických testů jaderných zbraní v 50. a 60. letech 20. století došlo téměř ke zdvojnásobení aktivity ${ }^{14} \mathrm{C}$ v životním prostředí ve srovnání s úrovní odpovídající přírodní, zejména kosmogenní, produkci tohoto radionuklidu. Radiouhlíková metoda vyu- živá této dočasně zvýšené aktivity ${ }^{14} \mathrm{C}$, která se na kalibrační křivce označuje jako bombový pík, k absolutnímu datování s vysokým časovým rozlišením $\mathrm{v}$ jednotkách let. $\mathrm{V}$ současnosti se ovšem aktivity ${ }^{14} \mathrm{C}$ vracejí $\mathrm{k}$ hodnotám před jadernými testy. Pro radiouhlíkové datování slonoviny, ale samozřejmě i jiných vzorků, to má nepříjemný důsledek, že totiž nelze určit, zda je slonovina recentní nebo pochází z období před rokem 1947. Pro současné a budoucí vzorky je proto nutné radiouhlíkové datování kombinovat s dalšími metodami tak, aby bylo možné zachovat vysoké rozlišení stanovení stáří artefaktů.

Jednou z možností je využití znalostí chronologie utváření klu. Na základě analýzy morfologie a rychlosti růstu klu slona afrického byly odebrány vzorky z různých hloubek a délek klu a analyzovány radiouhlíkovou metodou. Při interpretaci výsledků radiouhlíkové analýzy jsme využili informaci o vzájemném vztahu dílčích vzorků, vyplývající z chronologie růstu klu. Tímto postupem lze potlačit nejednoznačnost výsledků radiouhlíkového datování a zpřesnit časové intervaly. 


\title{
Aplikácia primárnych metód na báze LSC pri štandardizácii rádionuklidov
}

\author{
Ivana Bonková ${ }^{1}$, Jarmila Slučiak ${ }^{1}$, Matej Krivošík ${ }^{1}$ \\ ${ }^{1}$ Slovenský metrologický ústav \\ bonkova@smu.gov.sk
}

Hlavnou úlohou Oddelenia ionizujúceho žiarenia Slovenského metrologického ústavu (SMÚ) je výskum, vývoj a uchovávanie národných a ostatných etalónov $\mathrm{v}$ oblasti ionizujúceho žiarenia a odovzdávanie jednotiek do praxe na najvyššej metrologickej úrovni. Vzhladom na sprísňovanie noriem a limitov v oblasti ionizujúceho žiarenia sa výskumná činnost oddelenia, okrem iného, orientuje aj na zdokonalenie a vývoj nových meracích metód a postupov pre uchovávanie a prenos jednotky becquerel. Konzultatívny výbor Medzinárodného úradu pre váhy a miery v Sèvres, CCRI(II), ustanovil v roku 2007 pravidlo, že za klúčové porovnania sa akceptujú iba také, ktorých výsledky boli získané niektorou z primárnych, t.j. absolútnych metód merania, preto sme výskumnú činnost zamerali práve na túto oblast.

SMÚ v súčasnosti disponuje troma zariadeniami, ktoré fungujú na báze kvapalinovej scintilačnej analýzy, pričom tieto zariadenia umožňujú využívat tri primárne metódy stanovenia aktivity rádionuklidu. Prvým z nich je kvapalinový scintilačný analyzátor HIDEX 300SL, ktorý využíva trojdetektorové zapojenie a funguje na princípe počítania pomeru trojných a dvojných koincidencií, tzv. Metrologie, měření, přístrojová technika a její aplikace metóda TDCR (Triple to Double Coincidence Ratio). V roku 2019 oddelenie ukončilo budovanie druhého samostatného primárneho etalónu TDCR-G v rámci projektu APVV. Tento systém umožňuje používat metódu TDCR a vdaka prídavnej gama sonde umožňuje aj aplikáciu metódy $4 \pi \beta-\gamma$ koincidenčného merania. Tretím zariadením je Quantulus 1220. Toto meradlo má iba dve detekčné sondy, no vzhladom na pasívnu ochranu vo forme oloveného tienenia a aktívnu ochranu vo forme prídavného detekčného systému umožňuje meranie rádovo nižších aktivít, a rovnako ako zariadenie HIDEX 300SL, aplikáciu druhej najrozšírenejšej metódy CIEMAT/NIST.

Vo svojej práci sme sa zamerali na štandardizáciu rádionuklidov podliehajúcich čistej beta premene $\left({ }^{3} \mathrm{H},{ }^{35} \mathrm{~S}\right)$ a premene elektrónovým záchytom $\left({ }^{55} \mathrm{Fe}\right.$, ${ }^{54} \mathrm{Mn},{ }^{65} \mathrm{Zn}$ a pod.). V rámci potvrdenia presnosti výsledkov a zlepšovania kvality poskytovania referencie pri overovaniach sa oddelenie zapája aj do medzinárodných laboratórnych porovnaní. SMÚ úspešne prešlo klúčovým porovnaním zameraným na ${ }^{55} \mathrm{Fe}$. Momentálne sa zúčastňuje prebiehajúcej pilotnej štúdie týkajúcej sa štandardizácie ${ }^{60}$ Co a od júla roku 2021 participuje na klúčovom porovnaní ${ }^{109} \mathrm{Cd}$. 


\title{
Měření promptní gama z nepružného rozptylu AmBe neutronů $v \mathrm{D}_{2} \mathrm{O}$ sféře
}

\author{
Tomáš Czakoj ${ }^{1}$, Michal Koštál ${ }^{1}$, Jan Šimon ${ }^{1}, Z_{\text {deněk Matěj }}{ }^{2}$, Evžen Novák ${ }^{1}$ \\ ${ }^{1}$ Centrum Výzkumu Řež s.r.o \\ 2 Masarova Univerzita \\ tomas.czakoj@cvrez.cz
}

Promptní složka gama záření, vznikající při interakcích neutronů, at už při jejich záchytu nebo při jejich nepružném rozptylu, je významnou složkou gama záření ve směsných polích N/G. Jeho dobrá znalost je zásadní $\mathrm{v}$ různých oblastech, at $\mathrm{v}$ provozu reaktoru (reaktorová a vnitroreaktorová dozimetrie, radiační ochrana), či třeba v identifikaci prvků v půdě, či př́mo ve vesmíru. Tato práce prezentuje měřné gama záření produkovaného při nepružném rozptylu na ${ }^{16} \mathrm{O}$, a její srovnání $\mathrm{s}$ výpočtem různými knihovnami jaderných dat v kódu MCNP6.2. V experimentu byla použita sféra (průměr $50 \mathrm{~cm}$ ), vyrobené z hliníku a naplněná těžkou vodu v jejímž středu byl umístěn dobře popsaný Am-Be neutronový zdroj. Neutronová emise byla stanovena s pomocí manganové lázně, neutronové spektrum změřeno s pomocí ověřeného scintilačního detektoru. Vlastní měření fotonů z reakce ${ }^{16} \mathrm{O}\left(\mathrm{n}, \mathrm{n}^{\prime}\right)$ bylo realizováno s pomocí dobře popsaného HPGe detektoru (pro výpočetní určení odezvy detektoru) a pomocí stilbenu. Tato reakce byla studována zejména proto, že komunita jaderných dat definovala ${ }^{16} \mathrm{O}$ jako jeden $\mathrm{z}$ materiálů jejichž validace je nutná. To znamená, že experiment, ideálně benchmarkové kvality, pro stanovení promptního gama záření z kyslíku, by měl být realizován. 


\title{
Monte Carlo simulace sběru iontů polonia v elektrickém poli pro účely diagnostiky zařízení měřicího objemovou aktivitu radonu
}

\author{
Martin Kaschner, Michal Marčišovský, Pavel Staněk, Peter Švihra, \\ Vladimír Kafka
}

\author{
FJFI ČVUT v Praze
}

kaschner.martin@tesla.cz

Pro měření objemové aktivity radonu jsou běžně používána měřidla založená na sběru polonia na povrch polovodičového detektoru pomocí elektrického pole a následné detekci jeho přeměn. Samotný sběr je založen na $88 \%$ pravděpodobnosti vzniku nabitého iontu polonia ${ }^{218}$ Po při radioaktivní přeměně radonu ${ }^{222} \mathrm{Rn}$. Za účelem studia chování iontů polonia $\mathrm{v}$ měřidlech objemové aktivity radonu tohoto typu byla navržena a použita Monte Carlo simulace.

Byl vytvořen simulační model transportu a sběru iontů v atmosfére využívající procesy driftu iontů v elektrickém poli a difúze, s konkrétním zaměřením na ionty ${ }^{218}$ Po. Simulace je využita pro analýzu konkrétního zařízení (tvaru polokoule) a následně je navržena úprava, která by mohla vést $\mathrm{k}$ zvýšení citlivosti na radon bez zvětšení sběrného objemu zařízení, či bez použití většího napětí pro generování elektrického pole. Jed- noduchou úpravou parametrů lze simulaci použít i pro jiné ionty a geometrie zařízení.

Za pomoci popsané simulace sběru iontů bylo zjištěno, že pomocí stávající geometrie zařízení je možné sebrat $45 \%$ vzniklých iontů ${ }^{218}$ Po. Bylo zjištěno, že velká část objemu uvnitř zařízení není efektivně využita. Následně bylo navrženo a simulováno upravené zařízení, ve kterém je možno sebrat až $93 \%$ vzniklých iontů ${ }^{218} \mathrm{Po}$. Takováto úprava by mohla vést $\mathrm{k} 2,1 \times$ vyšší citlivosti než u předchozího modelu zařízení detekující radon. Jsou dále sledovány i jiné možné úpravy, ku př́íkladu sklon dna, ovšem je očekáváno zhoršení celkové citlivosti v důsledku zmenšení objemu měřidla. Je také sledován vliv hodnot difúzního koeficientu a elektrické mobility na výsledky simulace, který se projevuje zejména $\mathrm{v}$ době, kterou trvá dopad iontu ${ }^{218}$ Po na povrch detektoru. 


\title{
Úhlová a energetická kalibrace křemíkových stripových detektorů
}

\author{
Marek Sommer $^{1}$, Martina Lužová ${ }^{1}$, Michal Marčišovský ${ }^{2}$, \\ Mária Marčišovská ${ }^{2}$, Ondřej Ploc $^{1}$, Pavel Brož ${ }^{3}$, Pavel Krist ${ }^{1}$, \\ Petr Suchánek ${ }^{3}$, S. Kodaira ${ }^{4}$, Václav Vrba ${ }^{2}$ \\ ${ }^{1}$ Ústav jaderné fyziky AV ČR, v. v.i. \\ ${ }^{2}$ FJFI ČVUT v Praze \\ 3 evolving systems consulting Aerospace company, Praha \\ ${ }^{4}$ National Institutes for Quantum and Radiological Science and Technology \\ luzova@ujf.cas.cz
}

Stripové detektory jsou složené ze čtyř vrstev křemíkových detekčních čipů PH32. V každé vrstvě jsou dva tyto čipy o ploše $10 \times 20 \mathrm{~mm}^{2}$ a tlouštce $525 \mu \mathrm{m}$. Čip PH32 má 32 páskových vyčítacích elektrod s rozestupem $250 \mu \mathrm{m}$, které pokrývají plochu $8 \times 18 \mathrm{~mm}^{2}$ a zbytek plochy čipu tvoří guardringy. Celkem je tedy v každé vrstvě 64 stripů, díky kterým můžeme zjistit jednu souřadnici interagující částice. Vyčítací stripy v dalších vrstvách jsou vždy otočeny o $90^{\circ}$ a lze tedy dostat souradnice $\mathrm{X}$ a Y v horních dvou vrstvách i souřadnice $\mathrm{X}$ a $\mathrm{Y}$ ve spodních dvou vrstvách detektoru. Díky známým vzdálenostem mezi vrstvami můžeme určit úhel částice, která proletěla všemi čtyřmi vrstvami.
Příspěvek pojednává především o úpravách výpočtu úhlu z odezvy v jednotlivých stripech a porovnání úhlů změřených pomocí stripových detektorů a očekávaných při ozařování na urychlovači těžkých nabitých částic HIMAC v Japonsku. Zmíněna bude také energetická kalibrace pro nízké energie provedená pro každý strip pomocí dvou drobných radionuklidových zdrojů.

Krátce budou představeny plány do budoucna, ve kterých se počítá s využitím technologie stripových detektorů s čipy PH32 v kombinaci s tkániekvivalentním scintilátorem pro měření ve vesmírných misích. Znalost úhlu nalétávající částice pak umožní zjistit skutečné LET částice interagující v scintilačním krystalu. 


\title{
Spektrometrie vysokoenergetického fotonového záření na Lomnickém štítě detektorem RT56
}

\author{
Jakub Šlegl 1, 4 , Ronald Langer ${ }^{1,2}$, Igor Strhárský ${ }^{2}$, Jaroslav Chum ${ }^{3}$, \\ Iva Ambrožová ${ }^{1}$, Tomáš Brunclík ${ }^{5}$, Petr Mašek ${ }^{5}$, Ondřej Ploc ${ }^{1}$ \\ ${ }^{1}$ Ústav jaderné fyziky AV ČR, v. v. i. \\ ${ }^{2}$ Ústav experimentálnej fyziky SAV \\ ${ }^{3}$ Ústav fyziky atmosféry AV ČR, v.v.i. \\ ${ }^{4}$ Fakulta jaderná a fyzikálně inženýrská ČVUT v Praze \\ ${ }^{5}$ Georadis s.r. o. \\ slegl@ujf.cas.cz
}

Od srpna 2020 měří na Lomnickém štítě gama spektrometr RT56 of firmy Georadis s.r. o. $(\mathrm{NaI}(\mathrm{Tl})$ krystal $4 \times 4 \times 16$ palcư $\left.{ }^{3}\right)$ se zaznamenáváním každé události s časovou značkou z GPS. Detektor byl instalován za účelem doplnění informací z ostatních detektorů o probíhajících radiačních dějích během bouřek. Během bouřek dochází ke zvýšení fluence částic z důvodu urychlování částic mezi oblastmi náboje v oblaku. Nejběžnější je děj nazvaný Thunderstorm ground enhancement (TGE), kdy je na zemi naměřeno elektrickým mlýnkem silné (většinou negativní) elektrické pole. Lomnický štít je místo s častými silnými poli a je tudíž i se svou výš- kou $2634 \mathrm{~m}$ n.m., tedy svou blízkostí $\mathrm{k}$ oblakům, velmi vhodnou stanicí pro tento typ monitorování bouřek. $\mathrm{V}$ průběhu roku bylo událostí více, v tomto příspěvku budeme prezentovat vybranou - nejsilnější událost za poslední rok (12.9.2021), kdy energie fotonů přesáhla $9 \mathrm{MeV}$, a ukážeme přidanou hodnotu takového spektrometru $\mathrm{k}$ vyhodnocování událostí detektorem SEVAN a elektrickým mlýnkem EFM-100.

RT56 na Lomnickém štítě je součástí evropské sítě gama spektrometrů na vysokohorských observatořích, jejichž záznamy se ukládají na serveru ÚJF a je odsud umožněn i vzdálený přístup a ovládání. 


\title{
Měření Regener-Pfotzerova maxima za použití více typů detektorů ionizujícího záření a nového telemetrického systému
}

\author{
Jakub Kákona ${ }^{1}$, Martin Kákona ${ }^{2}$, Iva Ambrožová ${ }^{2}$, Marek Sommer $^{2}$, \\ Martin Povišer ${ }^{2}$, Martina Lužová ${ }^{2}$, Ondřej Ploc ${ }^{2}$ \\ ${ }^{1} \mathrm{CTU}$ - Faculty of Electrical Engineering \\ 2 ODZ, Ústav jaderné fyziky AV ČR, v.v.i. \\ kakonjak@fel.cvut.cz, luzova@ujf.cas.cz
}

Regener-Pfotzerovo maximum se nachází v takové nadmořské výšce, kde je intenzita kosmického záření největší. Je to okolo $20 \mathrm{~km}$, ale jeho přesná poloha závisí na mnoha parametrech jako jsou atmosférické podmínky, zeměpisná poloha, sluneční aktivita, ale také typ detekovaných částic. Při experimentálních letech stratosférických balonů používáme rozličné typy detektorů ionizujícího záření: Geiger-Müllerovo trubice, křemíkové detektory SPACEDOS a scintilační detektory AIRDOSC s NaI(Tl) krystalem.

Radiační měření jsou z důvodu zpracování dat doplněna o řadu dalších podpůrných senzorů měřících vlhkost, teplotu, polohu a orientaci, nadmořskou výšku, atmosférický tlak, zrychlení, atd. Všechny tyto snímače je jednak během startu stratosférického balonu nutné monitorovat pro ověření jejich správné funkce a dále, během letu, i zaznamenávat jejich hodnoty pro budoucí zpracování. $\mathrm{Z}$ tohoto důvodu byl během letů FIK-4 až FIK-5 postupně vyvinut telemetrický systém TF-ATMON, který uvedenou problematiku řeší. Systém je založen na použití existujících nástrojů open-source projektu PX4, který umožňuje kromě záznamu dat a jejich monitorování řešit i další související problematiku - Možnost dohledání gondoly balonu po provedeném letu. Z tohoto důvodu byl prvotně užívaný telemetrický systém podstatně zrobustněn a doplněn o IoT LoRa vysílač, který umožňuje přenášet data nezbytná pro nalezení gondoly do sítě TheThingsNetwork. Tímto způsobem je zajištěna vysoká spolehlivost nalezení gondoly a zaznamenání dat z aktivních detektorů. $\mathrm{V}$ př́ípadě aktivních detektorů je také důležité, že trajektorie letu je zaznamenána synchronně s podpůrnými veličinami.

Navržený systém TF-ATMON je velmi variabilní, proto je nyní použit i $\mathrm{v}$ jiných oblastech, než jsou balonová měření. Aplikace však bude demonstrována na stratosférických balonových letech pro měření parametrů RegenerPfotzerova maxima. 


\title{
Komplexné riešenie spojeného výskumu v oblasti radiačnej ochrany, havarijnej pripravenosti, odozvy a obnovy
}

\author{
Tatiana Ď́ranová \\ VUJE, Inc., Trnava, Slovensko \\ tatiana.duranova@vuje.sk
}

Prednáška poskytuje pohlad na ciele komplexného riešenia spojeného výskumu, ktoré boli analyzované a navrhnuté v rámci medzinárodného projektu EJP CONCERT. Takzvaná Joint Roadmap definuje priority a strategické ciele vzájomnej spolupráce a poskytuje víziu a úlohu Európskeho výskumného programu v oblasti radiačnej ochrany do roku 2030 a dalej. Joint Roadmap predstavuje pohlad na výskumné výzvy v kontexte existujúcich a možných scenárov expozície, ktoré sú relevantné vo vztahu k uhlu pohladu na spoločenskú a radiačnú ochranu. Spojený výskum v rámci týchto výziev dalej poskytuje "game changers“, definované ako výstupy výskumu, ktoré v prípade úspešného riešenia majú potenciál významne ovplyvnit a zosilnit systém a/alebo prax radiačnej ochrany človeka a/alebo životného prostredia. Prednáška sa podrobnejšie zaoberá aspektami optimalizácie havarijnej pripravenosti a manažmentu obnovy a odozvy a možnostami ich riešenia $\mathrm{v}$ spolupráci s členmi platformy NERIS v rámci Euratom Work Programme 2021-2022. 


\title{
Šr̃̃ení radioaktivních aerosolových částic $v$ prostředí tréninkového polygonu SÚJCHBO
}

\author{
Petr Otáhal $^{1}$, Jakub Ondráček ${ }^{2}$, Josef Vošahlík ${ }^{1}$, Eliska Fialova ${ }^{1}$, \\ Hana Sýbková ${ }^{1}$, Josef Holeček ${ }^{1}$, Michaela Kozlovská ${ }^{1}$, Eva Zemanová ${ }^{1}$ \\ 1 SÚJCHBO, v. v.i. \\ ${ }^{2}$ ÚChP AV ČR \\ otahal@sujchbo.cz
}

V rámci řešení projektu MV-ČR Velikostní distribuce aerosolových čásVH20182021036 - "Moderní metody tic s velmi detailním časovým rozlišedetekce a identifikace nebezpečných CBRN látek a materiáli̊, metody snížení jejich nebezpečnosti a dekontaminace; moderní prostředky ochrany osob“ byl v areálu SÚJCHBO, v. v.i. v Kamenné vytvořen unikátní polygon, který umožňuje studium šíření radioaktivních aerosolových částic $\mathrm{v}$ simulovaných podmínkách městské infrastruktury. Ve spolupráci s kolegy z AV ČR byl studován časový vývoj velikostní distribuce a koncentrace aerosolových částic vytvořených po explozi špinavé bomby obsahující Tc-99m. ním byla stanovována pomocí několika Skenovacích třídičů pohyblivosti částic (SMPS - TSI) a Aerodynamických třídičů částic (APS - TSI). V rámci experimentů byla sledována distribuce aerosolových částic jak v horizontálním tak vertikálním směru.

Získané výsledky budou potenciálně využity v rámci reakce na mimořádné události spojené s únikem radioaktivních látek nebo jaderných materiálů do životního prostředí ve formě radioaktivních aerosolových částic. 


\title{
Simulace dat pro výcvik terénních (pozemních i leteckých) skupin
}

\author{
Jan Helebrant, Jelena Burianová, Petr Kuča \\ Státní ústav radiační ochrany, v.v. i. \\ jan.helebrant@suro.cz
}

V rámci některých úloh řešených na Odboru havarijní připravenosti SÚRO a spolupracujícími subjekty je často užitečné mít $\mathrm{k}$ dispozici cvičná data formátem a strukturou odpovídající výstupům reálných, v terénu používaných př́strojů. Taková data jsou užitečná nejen pro nácvik zpracování dat / školení specialistů $\mathrm{v}$ rámci metodického zajištění činnosti MS SÚJB a MS dalších resortů, spolupráce na organizaci havarijních cvičení a nácviků MS (cvičení ZÓNA apod.), ale i pro testování používaných softwarových nástrojů, případně vývoj nových. $\mathrm{K}$ dispozici je sice několik demo souborů pro některé přístroje používané na SÚRO - např. Mob-
DOSE pro pojezdová měření či letecký spektrometr IRIS, ale jedná se o data s hodnotami na úrovni př́rodního pozadí.

Proto byly vytvořeny trasy fiktivních pojezdových měření odpovídající hodnotám za podmínek radiační mimořádné události na jaderné elektrárně Temelín. Cílem bylo vytvořit opět soubory formátu odpovídajícího přístroji Mob-DOSE - tj. aby takto vytvořené fiktivní měření bylo možné načíst a zpracovat standardními $\mathrm{SW}$ nástroji používaných na SÚRO (prohlížení program PEIView, vyhodnocovací program AGAMA) a byly také kompatibilní s databází MonRas. 


\title{
Comparison of the release of large-scale components and fragments of auxiliary equipment of V1 NPP
}

\author{
Matej Forgáč ${ }^{1}$, Branislav Vrban ${ }^{2}$, Vladimír Nečas ${ }^{3}$ \\ 1 Jacobs Slovakia s. r. o., Pieštanská 3, 91701 Trnava \\ 2 Slovak University of Technology in Bratislava, Institute of Nuclear and \\ Physical Engineering, Ilkovičova 3, 81219 Bratislava \\ 3 ÚJFI FEI STU, Bratislava \\ matej.forgac@gmail.com
}

The paper is devoted to the release of materials from dismantling activities during the decommissioning of NPP V1 (VVER-440). The focus is on monitoring the process of fragmentation of auxiliary equipment. Output materials are measured for surface contamination. According to the limit values, a decision is made on storage, decontamination, or direct release into the environment. A special category of ancillary equipment is large components that are not often used during power plant operation. These devices often consist of detachable sections. An example is the so-called Concrete container, consisting of three segments weighing more than 200 tons together. Due to the low usability in operation (during pressure vessel inspections), the total surface contamination probably meets the limits for release into the environment. However, as the measuring devices of the decommissioning process are not able to process materials that are not fragmented in the defined packaging files (load capacity max. 1 ton), it is necessary to fragment the sections of the concrete container to the required parameters. An alternative solution is to measure surface contamination on the entire surface of the device manually using hand-held instruments at a radiation-appropriate location. Released large-scale component can be demolished outside the KP by conventional methods not subject to radiation protection rules.

Result of this paper is comparison of secondary waste production (fragmentation tools) when releasing to environment two sections of Concrete container without fragmentation and dismantling third section inside area with radiation protection rules. 


\title{
Odhad radiační situace uvnitř a v blízkém okolí hlavního výrobního bloku jaderné elektrárny po havárii reaktoru typu VVER-1000
}

\author{
Tomáš Urban, Jaroslav Klusoň \\ KDAIZ FJFI ČVUT v Praze \\ tomas.urban@fjfi.cvut.cz
}

K odhadu radiační situace ve vybraných lokalitách uvnitř a blízkém okolí hlavního výrobního bloku (HVB) jaderné elektrárny (JE) s reaktorem typu VVER-1000 byl zvolen modelovací přístup metodou Monte Carlo. Geometrie HVB i model fixního zdrojového členu byly popsány pomocí př́islušných nástrojů kódu SCALE. Definice prostorové dispozice betonových příček v HVB (resp. prostory pro umístění technologií) vychází z jedné ze standardních koncepcí stavby HVB pro umístění reaktoru typu VVER-1000. Model fixního zdrojového členu byl popsán pro několik vybraných scénářů těžkých havárií (s únikem do kontejnmentu) a byl založený na předpokladu homogenní distribuce radionuklidů $\mathrm{v}$ jednotlivých částech/kompartmentech kontejnmentu. Energetické emisní spektrum zdroje bylo v simulačních výpo- čtech stanoveno na základě poměrového zastoupení radionuklidů přítomných $\mathrm{v}$ jednotlivých kompartmentech a výtěžků fotonů emitovaných při jejich radioaktivní přeměně.

V popsané simulační geometrii HVB a definici zdrojového členu byly odhadnuty (pomocí sekvence MAVRIC zakončené Monte Carlo kódem Monaco) př́kony prostorového dávkového ekvivalentu ve vybraných místech uvnitř a vně HVB (např. bloková dozorna, záložní dozorna, vstupní brána). Výsledky simulačních výpočtů byly vyhodnoceny (a dále diskutovány) z hlediska možnosti nasazení zasahujícího personálu v těchto oblastech.

Tato práce byla podpořena grantem MV ČR ev. č. VI20172020076 a grantem OPVVV reg. č. CZ.02.1.01/0.0/0.0/16_019/0000778 . 


\title{
ESTE CBRN - modelovanie radiačnej situácie po aplikácii špinavej bomby
}

\author{
Ludovít Lipták, Mária Marčišovská, Peter Čarný, Eva Fojcíková
}

ABmerit s.r.o.

liptak@abmerit.sk

Prezentované sú modely a prístupy ktoré slúžia/majú slúžit pracovníkom * SW nástroja ESTE CBRN určeného na modelovanie disperzie $v$ mestskej/priemyselnej zástavbe. Diskutované sú počiatočné podmienky v iniciačnej fáze udalosti. Súčastou príspevku sú ukážky práce s nástrojom ESTE CBRN a príklady výstupov, havarijnej odozvy po zlovolnej aplikácii RDD (Radiation Dispersion Device). V rámci príspevku sú diskutované aj výsledky dosiahnuté modelmi ESTE CBRN v rámci medzinárodných porovnaní. 


\title{
Stanovení transferových koeficientů pro dlouhodobější předpověd' úrovně radiační kontaminace zemědělské krajiny
}

\author{
Jan Procházka ${ }^{1}$, Kateřina Křováková ${ }^{1}$, Iva Šímová ${ }^{1}$, Jan Škrkal, Petr Rulík ${ }^{2}$ \\ ${ }^{1}$ Jihočeská univerzita v Českých Budějovicích, Zemědělská fakulta \\ 2 Státní ústav radiační ochrany, v. v.i. \\ prochaz@zf.jcu.cz
}

Rozdělení radiační kontaminace v krajině mezi půdu a rostlinu po neočekávané události a následný přestup radionuklidu z půdy do biomasy jsou závislé na mnoha faktorech (druhu rostliny, druhu půdy a jejích charakteristikách, druhu a chemické formě radionuklidu, velikosti srážek, místních podmínkách). V našich podmínkách si těžko můžeme dovolit nechat rozsáhlejší plochy zemědělské půdy ladem. $\mathrm{V}$ závislosti na úrovni kontaminace půdy lze vhodným výběrem komodity pro konkrétní oblast až do určité výše této kontaminace zajistit využití půdy $\mathrm{k}$ různým pěstitelským účelům, at už pro přímou lidskou spotřebu, nebo krmení hospodářských zvírat, kompostování, či jako zdroj pro výrobu energie $\mathrm{v}$ bioplynových stanicích, elektrárnách nebo spalovnách. V rámci havarijní prripravenosti a plánování následných opatření po radiační kontaminaci krajiny je potřebné mít znalosti o chování příslušného radionuklidu $\mathrm{v}$ různém prostředí jak v rané fázi, tak v dalších letech po nehodě. Zatímco v rané fázi po nehodě se ukázalo jako nejefektivnější opatření pro snížení kontaminace včasná sklizeň nadzemní biomasy, prrípadně shrnutí povrchové vrstvy půdy, v dlouhodoběj- ším měřítku je na kontaminované půdě potreba optimalizovat postupy rostlinné výroby vhodnou agrotechnikou a volbou pěstovaných plodin. $\mathrm{V}$ průběhu řešení relevantního projektu Bezpečnostního výzkumu (VI20192022153) byly $\mathrm{v}$ rámci dílčí studie zpracovány údaje o dynamice nadzemní biomasy a distribuci nejrozšířenějších plodin a půd v širším okolí našich jaderných elektráren (ETE a EDU), odebrány př́slušné vzorky a stanovena aktivita včetně transferových koeficientů (TK) půda - biomasa plodin u Cs-137 a K-40. Ke všem stanovením byla využita polovodičová spektrometrie gama, a protože aktivity Cs-137 byly zvláště v biotě velmi nízké, byly pro měření využity HPGe detektory (High Purity Germanium detectors) s vysokou relativní účinnosti (až $150 \%$ ) a dlouhé časy měření (několik dnů až týden). Průměrná aktivita $\mathrm{v}$ půdě $\mathrm{v}$ měřených vzorcích v okolí EDU a ETE v roce 2020 byla cca $14 \mathrm{~Bq} / \mathrm{kg}$ sušiny pro Cs-137 a $650 \mathrm{~Bq} / \mathrm{kg}$ sušiny pro K-40. Průměrná plošná aktivita odpovídala $1700 \mathrm{~Bq} / \mathrm{m}^{2}$ pro Cs-137. TK Cs-137 se pohybovaly od 0,001 do $0,2(\mathrm{~Bq} / \mathrm{kg} / \mathrm{Bq} / \mathrm{kg})$ sušiny rostliny i půdy. 


\title{
Projekt demontáže hlavných zariadení primárneho okruhu JE V1 v Jaslovských Bohuniciach
}

\author{
Tibor Rapant \\ JAVYS, a.s., Bratislava, Slovensko \\ rapant.tibor@javys.sk
}

Spoločnost JAVYS, v spolupráci s konzorciom Westinghouse-VUJE, v súčasnosti realizuje projekt spolufinancovaný prostredníctvom BIDSF fondu, ktorého úlohou je demontáž chladiacich systémov reaktora dvoch blokov typu VVER-440 v Jaslovských Bohuniciach. Prvý blok ukončil prevádzku 31. decembra 2006 a druhý 31. decembra 2008 po 28 rokoch prevádzky.

Rozsah prác projektu zahŕňa demontáž a nakladanie s odpadom v celkovej výške 9500 ton, medzi ktoré patria všetky hlavné komponenty primárnych okruhov (parogenerátory, hlavné cirkulačné čerpadlá a uzatváracie armatúry, kompenzátory objemu, primárne potrubie, atd'.), tlakové nádoby reaktora a vnútorné časti reaktora, vodná biologická ochrana a aktivovaný betón, sklad pevných RAO „Mogilnik“ a dalšie pomocné systémy a zariadenia.

Pretože plnenie časového harmonogramu a zároveň vysoká úroveň BOZP a radiačnej ochrany sú klúčové aspekty projektu, celková stratégia projektu bola založená na skorom uvolnení niektorých priestorov v kontrolo- vanom pásme, aby sa umožnilo vybudovanie nových zariadení, ktoré umožnia rýchlu a bezpečnú demontáž a fragmentáciu. Tieto počiatočné činnosti zohrali klúčovú úlohu v celom projekte, čo umožnilo navzájom oddelit činnosti suchého rezania od činností, ktoré sa realizujú pod vodou. Fragmentácia a balenie aktivovaných komponentov prebieha $\mathrm{v}$ dvoch novovybudovaných bazénoch mokrého rezania. Všetkých dvanást parogenerátorov bolo pretransportovaných do budovy bývalej strojovne, kde bolo vybudované pracovisko na suché rezanie parogenerátorov, čím sa využil velký volný priestor, ktorý v strojovni vznikol po demontáži sekundárneho okruhu. Na fragmentáciu zostávajúcich velkých zariadení a komponentov pomocných systémov boli v budove reaktora nainštalované dalšie dve dielne na suché rezanie (jedna na každom bloku).

Táto prezentácia popisuje celú projektovú stratégiu a prebiehajúce demontážne činnosti. Tiež sú prezentované doterajšie skúsenosti z realizácie prvého takéhoto komplexného projektu demontáže reaktorov typu VVER-440. 


\title{
Proces vyrad'ovania JE A1 a spracovanie RAO v JAVYS, a. s.
}

\author{
Dušan Krásny \\ JAVYS, a.s., Bratislava, Slovensko \\ krasny.dusan@javys.sk
}

Spoločnost JAVYS, a.s. v rámci SR zodpovedá za vyradovanie jadrových zariadení z prevádzky, za nakladanie s rádioaktívnymi odpadmi pochádzajúcimi z prevádzky a z vyradovania jadrových elektrární, za nakladanie s vyhoreným jadrovým palivom, za prevádzku úložiska rádioaktívnych velmi nízko a nízko aktívnych odpadov, ako aj za nakladanie s inštitucionálnymi rádioaktívnymi odpadmi.

$\mathrm{V}$ rámci týchto zodpovedností JAVYS, v spolupráci s firmou VUJE Trnava, realizuje aj projekt vyrad'ovania JE A1, ktorá bola odstavená z prevádzky v roku 1977 po dvoch udalostiach v rokoch 1976 a v roku 1977. Projekt vyradovania JE A1 je financovaný prostredníctvom Národného jadrového fondu SR. Cielom projektu je postupné vyradovanie jednotlivých častí JE A1 v piatich etapách s dôrazom na jadrovú a radiačnú bezpečnost celého procesu vyrad’ovania s predpokladaným termínom ukončenia projektu v roku 2033. Rozsah prác projektu zahŕňa demontáž zriadení JE A1 a nakladanie s rádioaktívnymi odpadmi z primárnej, a vzhladom na udalosti z rokov 1976 a 1977, aj sekundárnej časti JE A1. Táto prezentácia popisuje históriu, aktuálny stav a plán procesu vyradovania JE A1.

V dalšej časti prezentácie sú popísané postupy a technológie spracovania rádioaktívnych odpadov prevádzkované v JAVYS od ich vzniku až po ich finálne uloženie $\mathrm{v}$ Republikovom úložisku velmi nízko a nízko aktívnych rádioaktívnych odpadov v Mochovciach. 


\title{
Standardization of the database structures for data and information used in nuclear-decommissioning projects
}

\author{
Dušan Daniška, Branislav Vrban, Vladimír Nečas \\ ÚJFI FEI STU, Bratislava \\ dusan.daniska@gmail.com
}

The amount and variety of information used during the nuclear decommissioning project are enormous. If we consider that data and information coming from the whole operational phase of an NPP is important for safe and efficient planning of such projects and waste treatment, packaging, storage, and disposal use data coming from the dismantling operations, we can expect that nuclear-decommissioning data is live and can be useful for decades. Taking into account a very broad variety of such data (e.g., but not only, their for- mat, storage media, structure, meaning, relevancy,...) it is not a trivial task to develop a complex and reasonably structured database for storing all these data. This paper presents an overview of current research activities in the field of standardization in terms of the data structure and storage technologies where one of the goals of these activities is to outline the technology framework for building a so-called "single source of truth" for all data and information used during the nucleardecommissioning projects. 


\title{
Comparison of the background gamma-ray spectrum from soil obtained by direct measurement and by calculation using MCNP6 with $\mathrm{Nal}(\mathrm{TI})$ scintillation detector
}

\author{
Dávid Bednár ${ }^{1,2}$, Martin Lištjak ${ }^{2}$, Vladimír Nečas ${ }^{1}$ \\ ${ }^{1}$ ÚJFI FEI STU, Bratislava \\ ${ }^{2}$ VUJE, a. s. \\ david.bednar@stuba.sk
}

Efficiency calibration is an essential part of any gamma-spectrometric or non-spectrometric measurement. The article describes all necessary steps leading to the reconstruction of the gamma-ray spectrum from the soil mathematical calibration of the scintillation detector $\mathrm{NaI}(\mathrm{Tl})$ and subsequent optimization of the detector model in the MCNP6 code, determination of radionuclide vector of soil around NPP A1 and V1, calculation of the detector response matrix for selected gammaray energies of natural radionuclides in soil using the calculation code MCNP6 and finally the reconstruction of the gamma-ray spectrum. The results were compared in the energy range of 50$1620 \mathrm{keV}$ for the spectrum obtained by direct measurement of the soil sample and for the spectrum obtained by calcu- lation using the code MCNP6. The relative deviation in the whole spectrum between direct measurement and calculation is not more than $2 \%$, which can be considered as the satisfactory result. The scintillation detector model thus created, together with the determined soil radionuclide vector, can be used to calculate the response matrix for any measurement geometry, and thus determine the peak or total measurement efficiency under different conditions in practice in the field of decommissioning. The $2 \times 2$ inch. $\mathrm{NaI}(\mathrm{Tl})$ scintillation detector model thus created, together with the determined radionuclide vector of the soil, can be used to calculate the response matrix for any geometry arrangement, and thus determine the peak or total measurement efficiency under different conditions in practice. 


\title{
Príjem a distribúcia Sr-90 u rajčiaka jedlého ošetreného arbuskulárnymi mykoríznymi hubami
}

\author{
Silvia Dulanská ${ }^{1}$, Igor Gomola ${ }^{2}$, Lubomír Mátel ${ }^{2}$, Klára Gébeová $^{2}$ \\ ${ }^{1}$ Slovenská zdravotnícka univerzita, Lekárska fakulta UK \\ 2 Slovenská zdravotnícka univerzita \\ silvia.dulanska@szu.sk
}

\begin{abstract}
Arbuskulárne mykorízne huby (AMF) boli aplikované do koreňového systému rastlín rajčiaka jedlého (Solanum lycopersicum L.) s cielom zistit ich vplyv na príjem a distribúciu rádionuklidu ${ }^{90} \mathrm{Sr}$ v pletivách vybraných rastlín pestovaných za laboratórnych podmienok. Experimenty boli realizované $\mathrm{v}$ sterilnej zmesi ornice a piesku $\mathrm{v}$ pomere $2: 1$, kde v jednej sérii experimentov bola použitá kontaminovaná pôda $\mathrm{s}{ }^{90} \mathrm{Sr}$ a pri výseve boli semená inokulované zmesou AMF (Rhizoglomus irregulare, Funneliformis mosseae a Funneliformis caledonium) a v druhej, kontrolnej sérii boli sadené semená bez aplikácie AMF. Sta-

novenie ${ }^{90} \mathrm{Sr} \mathrm{v}$ pôde a $\mathrm{v}$ jednotlivých častiach rastlín rajčiaka sa uskutočnilo pomocou gamaspektrometrického merania. Získané výsledky poukazujú na signifikantnú súvislost medzi inokuláciou rastlín AMF a zmenou distribúcie ${ }^{90} \mathrm{Sr}$, kedy prítomnost AMF znížila translokáciu ${ }^{90} \mathrm{Sr}$ z koreňového systému do nadzemných častí rastlín rajčiaka jedlého.

Podakovanie: Práca vznikla s podporou projektu APVV-17-0150 „Interakcie arbuskulárnych mykoríznych húb $\mathrm{s}$ rastlinami v stresových podmienkach a ich potenciál pri fytoremediačných metódach".
\end{abstract}

76 Nakládání s radioaktivními odpady, vyřazování jaderných zařízení z provozu 


\title{
Bioplynová technologie - slibný způsob nakládání s rostlinnou biomasou kontaminovanou radionuklidy
}

\author{
Jan Škrkal ${ }^{1}$, Miroslav Kajan ${ }^{2}$, Věra Záhorová ${ }^{1}$ \\ ${ }^{1}$ Státní ústav radiační ochrany, v. v.i. \\ 2 Enki, o.p.s. \\ jan.skrkal@suro.cz
}

Bioplynová technologie je světově rozšířený zdroj elektrické energie umožňující zpracovat a redukovat odpadní biomasu. Byl proveden výzkum využitelnosti bioplynové technologie ke zpracování zemědělské biomasy kontaminované radionuklidy. Pro tento účel byly uskutečněny laboratorní experimenty s $20 \mathrm{l}$ modelovou bioplynovou stanicí (BPS) a provozní experimenty s komerční jihočeskou BPS. Travní a kukư̌ičná siláž byla vkládána do modelové BPS a následně byly stanovovány aktivity Cs-134 ve vstupních a vznikajících podílech. Modelové experimenty vedly průměrně $\mathrm{k} 50,6 \%$ snížení hmotnosti suché biomasy. Ve vzorcích kukư̌ičné a travní siláže, siláže z celých rostlin, pšenice, digestátu a aerosolu z komerční BPS byly změřeny aktivity Cs-137 a K-40. Fermentační proces v komerční BPS byl efektivnější, snížení hmotnosti suché biomasy dosáhlo $80 \%$. Střední hmotnostní aktivita suché biomasy $(1,37 \mathrm{~Bq} / \mathrm{kg})$ byla $4,4 \times$ nižší než aktivita sušiny digestátu $(6,01 \mathrm{~Bq} / \mathrm{kg})$. Aktivita Cs-137 v aerosolu z bioplynu byla $1,1 \times 10^{-7} \mathrm{~Bq} / \mathrm{m}^{3}$ a nižší a dekontaminační faktor procesu přeměny biomasy na bioplyn byl $3,8 \times 10^{6}$ a vyšší. Většina cesia zůstává v digestátu. Nebyla identifikována jiná cesta úniku radionuklidů. Vyprodukovaný digestát je možno sušit nebo stabilizovat a tato technologie je vhodná i ke zpracování kontaminované biomasy. 


\title{
Radón - náš neviditeliný spoločník
}

\author{
Monika Müllerová \\ Univerzita Komenského v Bratislave, Slovensko \\ monika.mullerova@fmph.uniba.sk
}

Radón je prírodný rádioaktívny plyn. Je klasifikovaný ako závažná karcinogénna látka. Radón pochádza z hornín a pôd. Odtial' sa šíri do okolia a má tendenciu sa hromadit v uzatvorených priestoroch, ako sú bane, jaskyne a domy. Vo vnútorných priestoroch a tiež vo vonkajšej atmosfére vykazuje koncentrácia radónu spravidla denné a sezónne variácie. Hlavným zdrojom radónu v domoch je jeho prísun z pôdy. Koncentrácia radónu v do- moch je ovplyvňovaná ich konštrukciou a ventiláciou. $\mathrm{V}$ prednáške bude zhrnuté, ako sa radón správa $\mathrm{v}$ rôznych médiách a ako sa dá merat. Budú prezentované možnosti jeho využitia $v$ environmentálnych štúdiách, ale tiež určenie radónového potenciálu pôd, na základe ktorého je možné ohodnotit danú lokalitu z hladiska možných zdravotných rizík súvisiacich s radónom v pobytových priestoroch. 


\title{
Analýza vplyvu zakrivenia dýchacích ciest na vyhodnotenie radónového rizika a jeho dôsledky I.
}

\author{
Radoslav Böhm, Karol Holý, Martin Bulko
}

Fakulta matematiky, fyziky a informatiky Univerzity Komenského

bohm1@uniba.sk

Podla údajov UNSCEAR, radón a jeho dcérske produkty sa podielajú s viac ako $55 \%$ na celkovej radiačnej zátaži obyvatelstva a po fajčení predstavujú druhý najvýznamnejší faktor ovplyvňujúci riziko vzniku rakoviny plúc.

Frakcia zmutovaných buniek z inhalácie radónu je ovplyvnená množstvom deponovanej energie, ktorá závisí od vzdialenosti zdrojov alfa častíc zachytených v mukóznej vrstve plúc. Táto vzdialenost sa $\mathrm{v}$ jednotlivých plúcnych generáciách mení s geometriou dýchacích ciest a ich zakrivením. Vo všeobecnosti možno predpokladat, že hrúbka mukóznej vrstvy, rovnako ako híbka terčových buniek v plúcnom tkanive, proporcionálne rastú s priemerom dýchacích ciest.

Vplyv rozmerov dýchacích ciest na radiačné riziko sme analyzovali pomocou jednoduchého geometrického modelu. Priedušky a priedušnice sme nahradili valcovými trubicami, ktorých vnútorný povrch bol pokrytý vrstvou mucusu a riasiniek. Jadrá terčových buniek sme aproximovali sférami s priemerom $d=5 \mathrm{~mm}$. Metódou Monte Carlo sme nasimulovali interakciu alfa častíc s terčovými bunkami a modelom prahovej energie sme vyhodnotili pravdepodobnost ich mutácie. Za referenčnú dýchaciu cestu sme považovali 4. generáciu, v ktorej podla epidemiologických výskumov s najväčšou pravdepodobnost dôjde k vzniku nádoru. Jej polomer je $R=2200 \mu \mathrm{m}$ a hrúbka mukóznej vrstvy je $h=11 \mu \mathrm{m}$. Híbka sekretorických buniek $\mathrm{v}$ tejto generácii je $h_{s}=20 \mu \mathrm{m}$ a bazálnych $h_{b}=40 \mu \mathrm{m}$. Každá iná dýchacia cesta bola $\varepsilon$ násobnou zmenšeninou referenčnej 4. generácie. Predpokladali sme, že v mukóznej vrstve sa nachádzajú v rôznych zastúpeniach zdroje alfa častíc, t.j. Po-214 a Po-218. Pomocou modelu sme vyhodnotili vplyv rozmerov dýchacích ciest na plúcnu a bunkovú dávku, ako aj na faktory kvality. Získané poznatky sme využili pri analýze radiačnej zátaže plúcneho tkaniva $\mathrm{v}$ závislosti od veku jedinca, ako aj pri vyhodnocovaní rádiosenzitivity bazálnych a sekretorických buniek plúcneho tkaniva.

Táto práca bola finančne podporovaná Vedeckou grantovou agentúrou MŠ SR a SAV (VEGA projekt č. 1/0213/18). 


\title{
Analýza vplyvu zakrivenia dýchacích ciest na vyhodnotenie radónového rizika a jeho dôsledky II.
}

\author{
Radoslav Böhm, Karol Holý, Martin Bulko \\ Fakulta matematiky, fyziky a informatiky Univerzity Komenského \\ bohm1@uniba.sk
}

Poznatky získané pri analýze vplyvu zakrivenia dýchacích ciest na radónové riziko sme využili v dvoch situáciách, pri ktorých dochádza $\mathrm{k}$ zmenšovaniu dýchacích ciest:

(1) Pri analýze zmeny radiačnej zát’aže plúcneho tkaniva od veku jedinca. Je všeobecne známe, že s vývojom jedinca dochádza k zmene rozmerov dýchacích ciest. Podla prác Sturma je možné z funkčnej zvyškovej kapacity (FRC) jedinca vyrátat, kolkonásobnou zmenšeninou referenčných plúc sú plúca s touto dýchacou charakteristikou FRC. Detské plúca sa však nedajú považovat len za zmenšenú verziu plúc dospelého jedinca, pretože zmenou štruktúry plúc sa mení aj fyziológia dýchania, presnejšie frekvencia dýchania a objem dychu. To má za následok, že účinnost depozície aerosólov na povrchu dýchacích ciest pri tom istom aerosólovom zložení prostredia sa mení s vekom a pri samostatnom vyhodnotení rizika to treba zohladnit. Analyzovali sme vplyv veku na dávku, faktor kvality, ako aj pravdepodobnost mutácie terčových buniek pre rôzne zastúpenia Po-214 a Po-218 v radiačnej zmesi zachytenej povrchom dýchacích ciest.

(2) Pri vyhodnocovaní rádiosenzitivity bazálnych a sekretorických buniek.
Plúcny strom je vlastne spojenie dýchacích ciest $\mathrm{s}$ rôznymi polomermi. Predpokladali sme, že terčové bunky sú v plúcnom tkanive heterogénne rozmiestnené, pričom v dolných dýchacích cestách sú prítomné len sekretorické bunky a v horných dýchacích cestách sa nachádzajú aj bunky bazálne. Podla modelu ICRP66 je citlivost oboch typov buniek rovnaká. Za tohto predpokladu, pravdepodobnost vzniku rakoviny plúc nekoreluje s deponovanou energiou $\mathrm{v}$ týchto častiach dýchacích ciest. Použitím mikrodozimetrického modelu prahovej energie, ktorý kvantifikoval pravdepodobnost vzniku rakoviny plúc, sme určili takú radiačnú citlivost buniek, aby pravdepodobnost vzniku rakoviny plúc z epidemiologických údajov korelovala s deponovanou energiou $\mathrm{v}$ jednotlivých plúcnych kompártmentoch. Na základe našich analýz môžeme konštatovat, že rádiosenzitivita bazálnych buniek je niekolkonásobne vyššia ako tých sekretorických.

Táto práca bola finančne podporovaná Vedeckou grantovou agentúrou MŠ SR a SAV (VEGA projekt č. 1/0213/18). 


\title{
Monitorovanie radónu vo vybraných materských školách na Slovensku
}

\author{
Monika Müllerová ${ }^{1}$, Karol Holý ${ }^{1}$, Patrícia Kureková, Iveta Smetanová ${ }^{2}$ \\ ${ }^{1}$ Fakulta matematiky, fyziky a informatiky Univerzity Komenského v Bratislave \\ ${ }^{2}$ Ústav vied o Zemi, Slovenská akadémia vied \\ monika.mullerova@fmph.uniba.sk
}

Na Slovensku bolo počas jedného roka monitorovaných 17 materských škôl. Vo vybraných materských školách bolo uskutočnené kontinuálne meranie objemovej aktivity radónu vo vnútornej atmosfére po dobu približne 2 týždňov, gamaspektrometrické meranie pôd okolitého pozemku a určenie objemovej aktivity radónu v pôdnom vzduchu. Najvyššie objemové aktivity radónu vo vnútornej atmosfére boli pomocou stopových detektorov zistené v čase letných prázdnin, ked' materská škola bola zatvorená po dobu jedného mesiaca. Kontinuálne meranie ukázalo maximá meraných objemových aktivít radónu počas víkendov. Priemerné ročné objemové aktivity radónu určené pomocou stopových detektorov v škôlkach boli v rozptyle od 75 do $1810 \mathrm{~Bq} / \mathrm{m}^{3}$. Objemová aktivita radónu v pôdnom vzduchu sa pohybovala v rozsahu 13 až $320 \mathrm{kBq} / \mathrm{m}^{3}$. Závislost medzi objemovou aktivitou radónu $\mathrm{v}$ pôdnom vzduchu a vnútorným ovzduším mala lineárny priebeh.

Táto práca bola finančne podporená Medzinárodným vyšehradským fondom (projekt č. 21510153) a Vedeckou grantovou agentúrou Ministerstva školstva SR a SAV (VEGA projekt č. 1/0213/18 a VEGA projekt č. 2/0083/18). 


\section{Zhodnotenie výsledkov pilotného radónoveho prieskumu v Slovenskej republike}

\section{Alexandra Kušnyerová ${ }^{1}$, Alžbeta Ďurecová ${ }^{2}$, Magdaléna Vičanová ${ }^{3}$, Veronika Durdyová ${ }^{1}$, Andrea Čipáková ${ }^{4}$, Kamila Kleinová ${ }^{4}$, Vladimír Trebichalský ${ }^{5}$}

${ }^{1}$ Odbor radiačnej ochrany, Úrad verejného zdravotníctva Slovenskej republiky

2 Oddelenie ochrany zdravia pred žiarením, Regionálny úrad verejného zdravotníctva so sídlom v Banskej Bystrici

${ }^{3}$ Odbor radiačnej ochrany, Regionálny úrad verejného zdravotníctva Bratislava hl. m. so sídlom v Bratislave

${ }^{4}$ Odbor ochrany zdravia pred žiarením, Regionálny úrad verejného zdravotníctva so sídlom v Košiciach

${ }^{5}$ Oddelenie radiačnej ochrany, Regionálny úrad verejného zdravotníctva so sídlom v Nitre

veronika.durdyova@uvzsr.sk

V dôsledku zmeny životného štýlu obyvatelstva $\mathrm{v}$ posledných desatročiach a v nadväznosti na prijaté opatrenia na úsporu energie $\mathrm{v}$ budovách je nevyhnutné preverit dávkovú zátaž obyvatelov $\mathrm{v}$ dôsledku ožiarenia radónom, a ak to bude potrebné, navrhnút preventívne a nápravné opatrenia. Geologické podložie, stavebné materiály, podzemná voda a pôdny vzduch sú potenciálnym zdrojom radónu v pobytových priestoroch.

Na účel identifikácie území so zvýšeným výskytom radónu a s použitím odborne a vedecky podložených kritérií založených na prieskume objemovej aktivity radónu v pobytových priestoroch a na pracoviskách, úrady verejného zdravotníctva Slovenskej republiky v spolupráci s Medzinárodnou agentúrou pre atómovú energiu so sídlom vo Viedni uskutočňujú vo vybraných 18 okresoch Slovenskej republiky, ktoré boli iden- tifikované na základe vopred stanovených kritérií, merania radónu v ovzduší pobytových priestorov, ktoré sú trvalo obývané rodinami s detmi do 18 rokov a gama žiarenia zo stavebných materiálov. Ide o pilotný radónový prieskum vykonávaný na území Slovenskej republiky a vychádza z výsledkov prvotného radónoveho prieskumu, ktorý bol realizovaný koncom 90. rokov.

Stopové detektory, ktoré boli v projekte použité na stanovenie objemovej aktivity radónu, budú vyhodnotené po ukončení prebiehajúceho merania v nevykurovacej sezóne. Výsledky vyhodnotenia termoluminiscenčných dozimetrov, ktoré boli použité na stanovenie gama žiarenia zo stavebných materiálov, poukazujú na skutočnost, že právna úprava prijatá v roku 1992, kedy sa implementovala regulácia aktivity prírodných rádionuklidov v stavebných materiáloch, prispela k zabezpeče- 
niu radiačnej ochrany obyvatelov pred účinkami gama žiarenia zo stavebných materiálov. Hodnoty príkonu priestorového dávkového ekvivalentu nameraného $\mathrm{v}$ pobytových priestoroch sa pohybujú na úrovni od (100-200) nSv/h, ktoré sú štandardné pre územie Slovenskej republiky.

Pokračovaním aktivít na reguláciu a usmerňovanie ožiarenia radónom bude implementácia stratégii Národného akč- ného radónoveho plánu, ktorý bude integrovaný s inými stratégiami ako kvalita vnútorného ovzdušia alebo úspora energie. Ukazovatelom úspešnosti bude zníženie počtu alebo percentuálneho podielu pobytových priestorov s objemovou aktivitou radónu nad referenčnou úrovňou alebo zníženie priemernej objemovej aktivity radónu v pobytových priestoroch a na pracoviskách. 


\section{„Radon-prone areas“ na území Slovenska predikované na základe preškálovaných máp radónového potenciálu}

\section{Alžbeta Brandýsová, Jozef Masarik, Karol Holý, Martin Bulko, Monika Müllerová}

Fakulta matematiky, fyziky a informatiky Univerzity Komenského v Bratislave alzbeta.brandysova@gmail.com

Viaceré vedecké štúdie ukázali, že vysoký obsah radónu v pôdnom prostredí môže byt prekurzorom jeho zvýšenej koncentrácie vo vnútorných priestoroch budov. Obývané oblasti, v ktorých sa očakáva zvýšená úroveň koncentrácie radónu v interiéri z prírodných (geogénnych) dôvodov, sú všeobecne nazývané tiež „radon prone areas". Tieto oblasti je možné identifikovat prostredníctvom priamych vnútorných meraní radónu, alebo nepriamym spôsobom, využitím pôdnych parametrov (koncentrácia ${ }^{226} \mathrm{Ra}$ a ${ }^{222} \mathrm{Rn}$, pórovitost, plynopriepustnost pôdy atd.) Na základe piatich nepriamych prístupov bola $\mathrm{v}$ rámci pilotnej štúdie stanovená predikcia radónového rizika v oblasti lokalizovanej v okolí Mochoviec $\left(\approx 24 \times 22 \mathrm{~km}^{2}\right.$, v ktorej bol obsah prírodných rádionuklidov $\left({ }^{238} \mathrm{U},{ }^{232} \mathrm{Th}\right.$, ${ }^{40} \mathrm{~K}$ a ${ }^{222} \mathrm{Rn}$ ) kvôli prítomnosti jadrovej elektrárne v minulosti dôkladne zmapovaný. Vytvorená mapa radónového potenciálu po jej následnom preškálovaní slúžila ako podklad pre identifikáciu vysokorizikových lokalít, kde boli vykonané merania objemovej aktivity radónu v domoch niektorých dedín zasahujúcich do týchto oblastí. Väčšina z týchto domov bola postavená pred rokom 1990, pričom v $53 \%$ prípadov bola referenčná úroveň koncentrácie radónu $\left(300 \mathrm{~Bq} / \mathrm{m}^{3}\right)$ v zimnom období prekročená. Z dosiahnutých výsledkov meraní vyplynulo, že nepriamy prístup stanovenia tzv. radon prone areas môže byt po zvolení vhodného preškálovania mapy radónového potenciálu účinným nástrojom pre vyhladávanie oblastí s vysokými koncentráciami radónu vo vnútorných priestoroch domov. Takto je možné postupovat pri vyhladávaní vysokorizikových lokalít aj v ostatných častiach Slovenskej republiky. Preto boli vytipované niektoré dalšie územia SR, pre ktoré bolo predikované radónové riziko pomocou preškálovaných máp radónového potenciálu. Celkom bolo zatial na Slovensku identifikovaných 99 obcí, kde môže ročná priemerná objemová aktivita radónu v domoch presahovat referenčnú úroveň $300 \mathrm{~Bq} / \mathrm{m}^{3}$. V týchto obciach by bolo vhodné prednostne začat prieskum objemovej aktivity radónu $\mathrm{v}$ domoch v rámci NARP SR. Navrhovaný prístup vyhladávania rizikových domov, v ktorých môže dôjst k vysokému ožiareniu radónom, je podla nás efektívnejší a lacnejší v porovnaní s celoplošným prieskumom. 


\title{
Emanácia radónu-222 z rôznych typov a druhov pôd
}

\author{
Terézia Eckertová, Karol Holý, Monika Müllerová, Ivan Sýkora, \\ Jozef Masarik
}

\author{
FMFI UK v Bratislave \\ eckertova3@uniba.sk
}

Klúčovým procesom, v dôsledku ktorého sa radón uvolnuuje $\mathrm{z}$ tuhej štruktúry pôdnych zín do pôdnych pórov, je emanácia a primárne tak predurčuje, kolko radónu sa môže uvolnit do okolitého prostredia. Napriek tejto skutočnosti, doteraz nie je tento proces plne pochopený a nie sú ani objasnené všetky faktory, ktoré naň vplývajú a do akej miery. Súčasne jediným spolahlivým spôsobom, ako určit emanáciu Rn-222 z nejakého pevného materiálu je priamo zmerat emanačný koeficient Rn-222 $\left(K_{e}\right)$ pre tento materiál. Pre tento účel sme vytvorili databázu $K_{e}$ pre rôzne pôdy zahrnutím rôznych pôdnych typov a druhov a skúmali pre ne aj vplyv vlhkosti na emanáciu radónu. Ukázalo sa, že velkost $K_{e}$ závisí nie len od aktivity rádia vo vzorke, ale je vo velkej miere ovplyvnená aj dalšími pôdnymi charakteristikami, ako je jej plynopriepustnost a $\mathrm{s}$ ňou súvisiace druhové zaradenie pôd. Tie rozhodujú nie len o sklone, ale aj o rýchlosti nárastu tejto krivky. Pre pôdy s vyššou plynopriepustnostou a s vyšším zastúpením zŕn väčších rozmerov narastali hodnoty $K_{e}$ so zvyšujúcou sa vlhkostou pozvolne, pre nízko priepustné pôdy s prevládajúcou frakciou zŕn menších rozmerov (pod $100 \mu \mathrm{m})$ bol nárast $K_{e}$ prudký. Pre oba druhy pôd od určitého obsahu vlhkosti sa hodnoty udržovali konštantné. Vierohodnost získaných výsledkoch je podložená detailným testovaním a porovnávaním akumulačných nádob $(\mathrm{AN})$, používaných na meranie emanačného koeficientu $K_{e}$.

Táto práca bola finančne podporovaná Vedeckou grantovou agentúrou MŠ SR a SAV (VEGA projekt č. 1/0213/18) a Grantom Mladých (č. grantu G-21-172-00). 


\title{
Štúdium vplyvu vlhkosti a velkosti pôdnych zín na emanáciu radónu $z$ pôd využitím nového mnohočasticového modelu
}

\author{
Terézia Eckertová, Karol Holý, Radoslav Böhm \\ FMFI UK v Bratislave \\ eckertova3@uniba.sk
}

Medzi najvýznamnejšie činitele, ovplyvňujúce emanáciu radónu z pôdnych častíc, je pôdna vlhkost a rozmer pôdnych zŕn. Oba tieto faktory svojím spôsobom upravujú dížku trajektórie, ktorú atóm radónu prejde $\mathrm{v}$ objeme pôdnych pórov. Prítomnost vlhkosti dokáže v pôdnom póre približne 1000 násobne skrátit dráhu ${ }^{222} \mathrm{Rn}$ v porovnaní s jeho dobehom vo vzduchu. Velkost pôdnych zŕn zas reguluje svojim usporiadaním velkost medzizrnných priestorov, ktoré sú úmerné práve rozmeru pôdnych častíc. Za účelom lepšieho porozumenia ich vplyvu na emanáciu sme vyvinuli vlastný výpočtový program, ktorý dokáže nasimulovat proces emanácie ${ }^{222} \mathrm{Rn}$ v pôdnom prostredí, použijúc myšlienku mnohočasticového modelu. V našom prípade je centrálne, radón emitujúce pôdne zrno, obklopené 342 prilahlými zrnami rovnakej velkosti tvoriac kubickú štruktúru a v priestore pôdnych pórov je rôzne rozložená vlhkoste. Simulácia procesu je postavená na dvojakom rozložení ${ }^{226} R a$ v pôdnych zrnách (homogénne aj heterogénne), pričom sú analyzované viaceré varianty únikovej hrúbky ${ }^{222} \mathrm{Rn}$ pre zrná rôznej velkosti a rôzny podiel vlhkosti. Emanačný koeficient ${ }^{222} \mathrm{Rn}$, v závislosti od vlhkosti, sleduje rôzne trendy podla velkosti pôdnych zŕn a je vo velkej miere ovplyvnený spôsobom rozloženia ${ }^{226} \mathrm{Ra} v$ pôdnych zrnách. Dosiahnuté výsledky závislosti emanačného koeficientu ${ }^{222} \mathrm{Rn}$ od vlhkosti potvrdzujú viaceré experimentálne merania a predikcie tohto modelu budú dalej podrobnejšie testované.

Táto práca bola finančne podporovaná Vedeckou grantovou agentúrou MŠ SR a SAV (VEGA projekt č. 1/0213/18) a Grantom Mladých (̌̌. grantu G-21-172-00). 


\title{
Posouzení dopadu výskytu Rn-222 v tělese odvalu a jeho blízkém okolí z hlediska radiační ochrany
}

\author{
David Strnad $^{1}$, Lenka Thinová ${ }^{2}$, Václav Štěpán ${ }^{2}$ \\ 1 ČVUT v Praze, Fakulta jaderná a fyzikálně inženýrská \\ 2 FJFI ČVUT v Praze \\ strnada4@fjfi.cvut.cz
}

Po těžbě uranu zůstávají po celém světě odvaly s hlušinou, z nichž se do okolního vzduchu uvolňuje radon. Většina odvali̊, které ještě nebyly rekultivovány nebo přepracovány, se v České republice nachází poblíž města Př́ibram. $\mathrm{Z}$ hlediska radiační ochrany je díky malé vzdálenosti od obcí Brod a Lešetice významný odval jámy č. 15 .

$\mathrm{Na}$ tomto odvalu byla $\mathrm{v}$ rámci bakalářské práce provedena řada měření ve spolupráci se SÚRO, v.v.i., SÚJCHBO v. v. i. a Diamo s.p. V šestnácti měřících bodech byla od 28. 5. 2021 do 15. 6. 2021 sledována objemová aktivita radonu (dále OAR), dále bylo v měřících bodech pomocí GT-40 odhadnuto množství $\mathrm{U}$, Th, $\mathrm{K}$ a ${ }^{137} \mathrm{Cs}$, př́kon prostorového dávkového ekvivalentu a pomocí iontometru pak počet záporných iontů. U paty odvalu byla pomocí termokamery lokalizována místa s výrazným výdechem chladného vzduchu a $\mathrm{v}$ jednom $\mathrm{z}$ nich byla pomocí anemometru čtyři dny měřena rychlost proudění vzduchu z/do odvalu a jeho teplota. Pro kontinuální měření OAR bylo na odval umístěno celkem 26 sond Tesla TSR v 16 měřících bodech, které se nacházely u paty odvalu (v hlušině a ve výšce $1,5 \mathrm{~m}$ na stromě), na stěně odvalu a na koruně odvalu. Nejvyšší průměrná hodnota OAR naměRadon a přírodní zdroje ionizujícího záření řená v měřícím bodu u paty odvalu činila $27122 \mathrm{~Bq} / \mathrm{m}^{3}$. OAR zaznamenané sondami na stromech mnohonásobně překračují v ovzduší běžnou hodnotu $5 \mathrm{~Bq} / \mathrm{m}^{3}$.

Podle dřívějších studií z Německa, Kanady, Austrálie a Ceské republiky je tok plynu odvalem řízen především rozdílem teplot uvnitř a vně odvalu, přičemž důsledkem jsou značné denní variace $\mathrm{v}$ hodnotách OAR v různých měřících bodech. Výsledky provedeného měření tuto hypotézu potvrzují. Nejvyšší hodnoty OAR v měřících bodech $\mathrm{u}$ paty odvalu byly naměřeny $\mathrm{v}$ nočních hodinách a mohou být opožděnou reakcí na vyšší teploty v odpoledních hodinách, při kterých plyn proudí odvalem směrem dolů a vystupuje $u$ jeho paty. Velmi dobrá shoda byla navíc nalezena mezi hodnotami OAR na stanici RAMONIS u obce Brod a daty ze tří sond umístěných na přivrácené straně odvalu - lze dovozovat, že přinejmenším situace na hranicích obce Brod je přímo ovlivňována plynem uvolňovaným z odvalu.

V rámci př́spěvku představíme data z kontinuálního měření OAR a budeme diskutovat jejich souvislosti s parametry prostředí a výsledky předchozích měření a studií. 


\title{
Modelování uhlíkového a radiouhlíkového cyklu na Zemi
}

\author{
David John, Kundrát Pavel, Ivo Světlík, Kateřina Pachnerová Brabcová
}

\author{
ÚJF AV ČR, v.v.i.
}

john.david@seznam.cz

Zejména v souvislosti s klimatickými změnami je $\mathrm{v}$ současné době rostoucí pozornost věnována uhlíkovému cyklu. Toky mezi jednotlivými rezervoáry se monitorují pomocí lokálně a časově proměnlivých koncentrací $\mathrm{CO}_{2}$ a radioaktivního izotopu uhlíku ${ }^{14} \mathrm{C}$. Ten je přirozeně produkován kosmickým zářením ve svrchních vrstvách atmosféry, ale testování jaderných zbraní v polovině 20. století významně navýšilo jeho přirozený výskyt. Tento antropogenní ${ }^{14} \mathrm{C}$ se postupně šíril $\mathrm{v}$ atmosfére a pronikl i do biosféry a do oceánů.

Matematické modely umožnují dávat různá měřená data do souvislostí a formulovat závěry, např. odhadovat budoucí vývoj koncentrací $\mathrm{CO}_{2} \mathrm{v}$ atmosféře pro různé emisní scénáře. Modely mohou být použity $\mathrm{k}$ navrhování nebo vyvracení hypotéz, což by se z izolovaných pozorování dalo provést jen velmi obtížně. Modely také mohou pomoci pochopit tzv. kalibrační křivku ${ }^{14} \mathrm{C}$. Ta se používá $\mathrm{v}$ radiouhlíkovém datování $\mathrm{k}$ tomu, aby bylo možné z konvenčního radiouhlíkového stáří, které vyjadřuje množství ${ }^{14} \mathrm{C} v$ měřeném vzorku, odvodit kalendářní stáří vzorku. Na této křivce existuje řada dosud nedostatečně vysvětlených jevů - strmých poklesů, vzestupů, dlouhodobých plochých oblastí či naopak extrémních maxim koncentrovaných do krátkých ča- sových úseků. Studium jiných kosmogenních izotopů ukázalo, že některé z těchto jevů je pravděpodobně možné spojovat s procesy extraterestriálního původu, zejména se změnami sluneční aktivity. U jiných však tato vysvětlení podle současného stavu poznání nepřipadají v úvahu, ale mohlo by se jednat o vliv mimořádných sopečných činnosti, např. podmořských vulkánů. Je ovšem také možné, že budoucí výzkum odhalí, že na uhlíkové bilanci se lidé výrazně podíleli již s nástupem zemědělství a historicky raných zásadních změn v krajině.

V příspěvku představíme globální modely uhlíkového cyklu využívající principu redukce geometrie a průměrování. Reálný trojrozměrný oceán, který je hlavním rezervoárem uhlíku, je např́klad typicky popsán jako svrchní vrstva, ve které probíhá výměna $\mathrm{CO}_{2}$ s atmosférou, a jednorozměrné difúzní médium popisující hluboké části oceánů. Tento přístup vede $\mathrm{k}$ výraznému snížení výpočetní náročnosti a redukci počtu parametrů modelu oproti realističtějším modelům s vyšším prostorovým rozlišením, u nichž lze mnohé parametry jen zhruba odhadovat. Uvedeme srovnání modelových simulací s měřenými daty pro atmosférické množství $\mathrm{CO}_{2}$ a ${ }^{14} \mathrm{C}$. Prodiskutujeme předpovědi budoucího vývoje atmosféry. 


\title{
Radón vo vnútornom ovzduší vybraných budov v obci Vydrník (Vikartovský zlom, Slovensko)
}

\author{
Iveta Smetanová ${ }^{1}$, Andrej Mojzeš ${ }^{2}$, Kristian Csicsay ${ }^{1}$, František Marko ${ }^{2}$ \\ ${ }^{1}$ Ústav vied o Zemi, Slovenská akadémia vied \\ 2 Prírodovedecká fakulta, Univerzita Komenského v Bratislave \\ iveta.smetanova@savba.sk
}

Výskum objemovej aktivity ${ }^{222} \mathrm{Rn}$ ovaný informačný leták o radóne a dov ovzduší vybraných rodinných domov, škôl, materských škôl a úradov sa uskutočnil v rámci riešenia projektu „Multidisciplinárny výskum geofyzikálno štruktúrnych parametrov a environmentálneho vplyvu zlomov Západných Karpát" v troch obciach na Slovensku ležiacich na zlomových pásmach. V obci Vydrník, ktorá leží v blízkosti Vikartovského zlomu, sa meranie vykonávalo v 23 budovách, spolu v 43 miestnostiach. Meranie bolo realizované integrálne, pomocou stopového detektora alfa častíc RAMARn (SÚJCHBO, ČR). Radónový monitoring prebiehal počas jedného roka, detektory boli vymieňané po trojmesačnej expozícii (jún-august 2018, september-november 2018, december 2018-február 2019, marec-máj 2019). Spolu s detektormi bol dobrovolným účastníkom výskumu distributazník, ktorým sa zistovali základné informácie o budove (stavebný materiál, intenzita vetrania, podpivničenie, tesnost okien, rok konštrukcie a rekonštrukcie). Priemerná objemová aktivita radónu za rok sa $\mathrm{v}$ monitorovaných miestnostiach pohybovala $\mathrm{v}$ intervale $60-940 \mathrm{~Bq} / \mathrm{m}^{3}$. Vo väčšine monitorovaných miestností vykazovala objemová aktivita radónu sezónnu zmenu s maximom $\mathrm{v}$ jesenných a zimných mesiacoch. V okolí budovy, v ktorej objemová aktivita ${ }^{222} \mathrm{Rn}$ prekročila referenčnú úroveň $300 \mathrm{~Bq} / \mathrm{m}^{3}$ v priemere za rok, bolo vykonané aj meranie objemovej aktivity radónu $\mathrm{v}$ pôdnom vzduchu. Výskum bol finančne podporený vedeckou grantovou agentúrou APVV MŠ SR v rámci projektu APVV-16-0146 a VEGA MŠ SR a SAV v rámci projektu VEGA 2/0015/21. 


\title{
Př́pad zvýšeného výskytu ${ }^{210}$ Po v pitné vodě
}

\section{Růžena Šináglová, Ivana Ženatá}

\author{
Státní úřad pro jadernou bezpečnost \\ ruzena.sinaglova@sujb.cz
}

Tématem příspěvku je informace o případu náhlého zvýšeného výskytu ${ }^{210} \mathrm{Po}$ v dodávané pitné vodě. Zjištění všech skutečností souvisejících s případem bylo provedeno v rámci dozoru SÚJB $\mathrm{v}$ oblasti přírodních zdrojů. Měření pitné vody byla předána SÚJB dodavatelem vody (povinnost zajistit systematické měření a hodnocení obsahu př́rodních radionuklidů $\mathrm{v}$ pitné vodě prostřednictvím držitele povolení $\mathrm{k}$ této činnosti) a laboratoří SÚRO v.v.i. v rámci podpory dozoru SÚJB.

Vodovod, ve kterém byl výskyt ${ }^{210} \mathrm{Po}$ zaznamenán, je v provozu od roku 2005, celková objemová aktivita alfa (COAA) je zde dlouhodobě nízká $(0,02 \mathrm{~Bq} / \mathrm{l})$. V březnu 2020 byl v blízkosti stávajícího zdroje z důvodu nedostatku vody vyvrtán nový hluboký vrt k jeho posílení, vysoký obsah těžkých kovů však znemožnil jeho další využití. V květnu 2020 byla při pravidelném každoročním měření vody ve vodovodu zjištěna nečekaně vysoká hodnota COAA 1,4 Bq/l. Odběrem vody v červenci 2020 bylo prokázáno, že na COAA se největší mírou podílí ${ }^{210} \mathrm{Po}(\mathrm{COAA} 0,4 \mathrm{~Bq} / \mathrm{l}$, $\left.{ }^{210} \mathrm{Po} 0,2 \mathrm{~Bq} / \mathrm{l}\right)$. Měření vody provedené v rámci dozoru SÚJB v srpnu 2020 zjistilo COAA již pod vyšetřovací úrovní (COAA 0,17 Bq/l), v březnu 2021 již byly výsledky COAA srovna- telné s předchozími roky. $\mathrm{V}$ průběhu roku 2021 prováděl SÚJB opakovaná měření pitné vody $\mathrm{z}$ vodovodu a surové vody z vrtu. Hodnoty obsahu přírodních radionuklidů v pitné vodě odpovídaly již zcela hodnotám vykazovaným v letech 2005-2019. V surové vodě $\mathrm{z}$ vrtu byl zjištěn vysoký obsah radonu (2 $800 \mathrm{~Bq} / \mathrm{l})$, COAA (1,14 Bq/l). Situace byla vždy plně vysvětlena př́tomností ${ }^{210}$ Po. Lze předpokládat, že v období od března do července 2020 se v dodávané vodě vyskytovalo ${ }^{210} \mathrm{Po}$ krátkodobě $\mathrm{v}$ důsledku kontaminace radonem patrně $\mathrm{v}$ důsledku změny hydrologických poměrů v lokalitě. Měřeními bylo prokázáno, že šlo jen o krátkodobý jev. ${ }^{210} \mathrm{Po}$ je členem uranové rozpadové řady a je dceřiným produktem ${ }^{222} \mathrm{Rn}$. Protože dceřiné prvky pocházejí z radonu rozpuštěného ve vodě, jsou ve vodě jemně rozptýleny a tvoří $\mathrm{v}$ podstatě pravý roztok, $\mathrm{z}$ pevných uranových rud by se ${ }^{210} \mathrm{Po}$ do vody v takové míre neuvolnilo. Popisovaný př́pad ukazuje na potřebu věnovat pozornost tomu, že radon rozpuštěný ve vodě může být příčinou výskytu ${ }^{210} \mathrm{Po}$ i v takových podzemních vodách, které nepřicházejí do př́mého styku s podložím obsahujícím uran. $\mathrm{V}$ takových případech pak není aktivita alfa, jako to ve většině př́ipadů rozborů pitných vod 
očekáváme, tvořena uranem a radiem, ale výhradně jen konečnými rozpadovými produkty radonu. 


\section{Bulgarian instruments for space radiation dosimetry and main scientific results}

A. Kozyrev ${ }^{1}$, A. Malahov ${ }^{1}$, B. Tomov ${ }^{2}$, Tsvetan Dachev ${ }^{3}$, A. Sanin ${ }^{1}$, A. Vostrukhin ${ }^{1}$, D. Golovin ${ }^{1}$, D.P. Häder, E.N. Yarmanova ${ }^{4}$, F. Fedosov', F. Spurny ${ }^{5}$, G. Horneck ${ }^{6}$, G. Reitz ${ }^{6}$, H. Kitamura ${ }^{7}$, I. Chernykh ${ }^{4}$,

I. Mitrofanov' ${ }^{1}$, I. Nikolaev ${ }^{8}$, J. Kubancak ${ }^{5}$, J. Semkova ${ }^{2}$, K. Krastev ${ }^{2}$, M. Jordanova ${ }^{2}$, M. Lebert ${ }^{9}$, M. Litvak ${ }^{1}$, M. Mokrousov ${ }^{1}$, M.T. Schuster ${ }^{9}$, N. Bankov ${ }^{2}$, N. Grebennikova ${ }^{1}$, O. Ploc ${ }^{5}$, O.A. Ivanova ${ }^{4}$, P. Dimitrov ${ }^{2}$, R. Koleva ${ }^{2}$, S. Nikiforov ${ }^{1}$, St. Malchev ${ }^{2}$, V. Petrov ${ }^{4}$, V. Tretyakov ${ }^{1}$, V.A. Shurshakov ${ }^{4}$, V.V. Benghin ${ }^{4}$, Y. Uchihori ${ }^{7}$, Yu. Matviichuk ${ }^{2}$

${ }^{1}$ Space Research Institute, Russian Academy of Sciences, Moscow, Russia

2 Space Research and Technology Institute, Bulgarian Academy of Sciences, Sofia, Bulgaria

${ }^{3}$ Space Research and Technology Institute, Bulgarian Academy of Sciences ${ }^{4}$ State Research Center Institute of Biomedical Problems, Russian Academy of Science, Moscow, Russia

${ }^{5}$ Nuclear Physics Institute, Czech Academy of Sciences, Prague, Czech Republic

${ }^{6}$ Deutsches Zentrum für Luft- und Raumfahrt e.V., Köln, Germany

${ }^{7}$ National Institute of Radiological Sciences, Chiba, Japan

${ }^{8}$ S.P. Korolev Rocket and Space Corporation Energia, Korolev town, Russia

${ }^{9}$ Friedrich-Alexander-Universität, Department for Biology, Erlangen, Germany tdachev59@gmail.com

Ionizing radiation is recognized to be one of the main health concerns for humans in the space environment. Estimation of space radiation effects on health requires the accurate knowledge of the accumulated absorbed dose, which depends on the global space radiation distribution, solar cycle and local shielding generated by the $3 \mathrm{D}$ mass distribution of the space vehicle. We presnt an overview of the spectrometer-dosimeters of the Liulin type, which were developed in the late 1980s and have been in use since then. Two major measurement systems have been developed by our team. The first one is based on one silicon detector and is known as a Liulin-type deposited energy spectrometer(DES) (Dachev et al., 2002, 2003), while the second one is a dosimetric telescope (DT) with two or three silicon detectors. The Liulintype instruments were calibrated using a number of radioactive sources and particle accelerators. The main results of the calibrations are presented in the presentation. Some of the most significant scientific results obtained in space and on aircraft, balloon and rocket flights since 1989 are presented also. 


\title{
Vliv pandemie COVID-19 na dozimetrii posádek letadel v Česku a na Slovensku
}

\author{
Ondřej Ploc ${ }^{1}$, Iva Ambrožová ${ }^{1}$, Ivan Kováŕr ${ }^{1}$, Martin Kákona ${ }^{1}$, \\ Ján Kubančák ${ }^{2}$, Martina Lužová ${ }^{1}$, Marek Sommer ${ }^{1}$, Dagmar Štěpánová, \\ Karel Turek ${ }^{1}$, Olena Velychko ${ }^{1}$ \\ ${ }^{1}$ Ústav jaderné fyziky AV ČR, v. v. i. \\ 2 Institute of Experimental Physics, Slovak Academy of Sciences, Watsonova 47, \\ Košice 040 01, Slovakia, Ministry of Transport and Construction, Námestie \\ slobody 6, Bratislava 810 05, Slovakia \\ ploc@ujf.cas.cz
}

Pandemie COVID-19 citelně zasáhla do mnoha lidských činností včetně letecké dopravy. Výrazně omezena či úplně zrušena byla zejména osobní letecká přeprava cestujících na linkových letech. Omezení se týkalo rovněž aerotaxi služeb a privátních letů. V rutinní dozimetrii posádek letadel, která se provádí výpočtem, se tato omezení projevila sníženou kolektivní dávkou leteckého personálu, ale v některých případech navýšením průměrné roční efektivní dávky z důvodu většího vytížení menšího počtu personálu. Nicméně i v průběhu přísných lockdownů se podařilo realizovat několik srovnávacích verifikačních letů s mnoha typy dozimetrů kosmického záření. Pokračovalo se také $\mathrm{v}$ dlouhodobých měřeních $\mathrm{s}$ polovodičovými detektory Liulin a AIRDOS na palubách letadel Smart Wings a ABS Jets. V příspěvku bude prezentován jednak rozbor rutinní dozimetrie posádek letadel v Česku a na Slovensku, a jednak srovnání výsledků verifikačních měření na palubách letadel dozimetry s výpočty programem CARI-7. 


\title{
Mnohokomponentné analýzy pôdy a atmosféry a ich aplikácie
}

\author{
Karol Holý, Monika Müllerová, Markus Helej, Terézia Eckertová, \\ Martin Bulko, Ivan Sýkora, Ivan Kontul', Jozef Masarik, Radoslav Böhm
}

Katedra jadrovej fyziky a biofyziky, Fakulta matematiky, fyziky a informatiky, Univerzita Komenského v Bratislave

monika.mullerova@fmph.uniba.sk

Pre riešenie viacerých environmentálnych problémov je potrebné uskutočňovat multiizotopové analýzy rádionuklidov v rôznych zložkách životného prostredia, ako sú najmä pôda a atmosféra. V areáli Fakulty matematiky, fyziky a informatiky UK v Bratislave (FMFI) boli postupne uvedené do prevádzky rôzne meracie systémy a postupy, ktoré umožňujú: kontinuálne monitorovanie objemovej aktivity radónu, objemových aktivít jeho krátkožijúcich produktov premeny a $\mathrm{CO}_{2} \mathrm{v}$ atmosfére, uskutočňovat dlhodobé odbery atmosférických aerosólov na filtre s ich následnou analýzou pomocou HPGe detektorov, simultánne meranie koncentrácií radónu a $\mathrm{CO}_{2} \mathrm{v}$ rôznych híbkach pôdy, merania exhalácie radónu a $\mathrm{CO}_{2}$ z pôdy. Paralelne sú v areáli meteorologických pozorovaní FMFI získavané údaje o meteorologických prvkoch. V areáli FMFI sú tiež sledované zmeny koncentrácie ${ }^{14} \mathrm{C}$ v atmosférickom a pôdnom $\mathrm{CO}_{2}$ a tiež exhalácia ${ }^{14} \mathrm{C}$ z pôdy.

Výsledky uvedených meraní umožňujú študovat zmeny koncentrácie rádionuklidov v atmosfére (radónu a jeho produktov premeny, ${ }^{7} \mathrm{Be},{ }^{210} \mathrm{~Pb}$, ${ }^{40} \mathrm{~K}$ a ${ }^{137} \mathrm{Cs}$ ), študovat časovú variabi- litu rovnovážneho faktora medzi radónom a jeho krátkožijúcimi produktmi premeny $\mathrm{v}$ atmosfére, určovat dobu zotrvania aerosólov v atmosfére, určovat jej zmiešavaciu výšku a tiež hodnotit výmenné procesy v atmosfére. Simultánne meranie radónu a $\mathrm{CO}_{2} \mathrm{v}$ pôde umožňujú sledovat vplyv meteorologických podmienok na ich koncentráciu, ale hlavne testovat možnost využitia ${ }^{222} R n$ pre určovanie reprezentatívnych tokov $\mathrm{CO}_{2}$ z pôdy do atmosféry. Radón môže byt tiež užitočným nástrojom pre výpočet emisií fosílneho $\mathrm{CO}_{2}$ do atmosféry na základe „radon-tracer" metódy. Dáta o ${ }^{14} \mathrm{C}$ v atmosfére umožňujú sledovanie kontaminácie atmosféry fosílnym $\mathrm{CO}_{2}$ a spolu s ${ }^{222} \mathrm{Rn}$ umožňujú vypočítat emisné rýchlosti fosílneho $\mathrm{CO}_{2}$ do atmosféry. To môže pomôct napr. pri kontrole plnenia záverov z Parížskej klimatickej konferencie COP21.

$\mathrm{V}$ príspevku budú uvedené hlavne výsledky merania koncentrácií radónu, jeho produktov premeny a $\mathrm{CO}_{2} \mathrm{v}$ atmosfére a tiež radónu a $\mathrm{CO}_{2} \mathrm{v}$ pôde, ako aj ich exhalácie z pôdy. Analyzovaná bude možnost ich aplikácií pri riešení niektorých environmentálnych problémov. Dôraz bude kladený tiež na rádiohygienické aplikácie. 
Táto práca bola finančne podporovaná Vedeckou grantovou agentúrou MŠ SR a SAV (VEGA projekt č. 1/043/18) a Grantmi mladých UK (̌̌. G-21-172-00, G-21-202-00). 


\title{
Review of important space weather events observed at the Lomnický štít high mountain observatory
}

\author{
Ján Kubančák ${ }^{2}$, Igor Strhársky ${ }^{1}$, Dagmar Štěpánová ${ }^{3}$, Iva Ambrožová ${ }^{3}$, \\ Ondřej Ploc ${ }^{3}$, Pavol Bobík ${ }^{1}$, Ronald Langer ${ }^{1}$, Šimon Mackovjak ${ }^{1}$ \\ ${ }^{1}$ Ústav experimentálnej fyziky SAV \\ 2 Ministerstvo dopravy a výstavby SR \\ 3 Ústav jaderné fyziky AV ČR, v. v.i. \\ jan.kubancak@mindop.sk
}

Lomnický štít Neutron Monitor of the istered at the observatory. In our conDepartment of Space Physics, Institute tribution, we will present a survey of of Experimental Physics, Košice, Slo- most important ones and present the fuvakia is continually in operation from ture plans for the cosmic rays research December 1981. Since then, many im- at the observatory.

portant space weather events were reg- 


\title{
Modelování dávkového příkonu gama uvnitř kalibrační základny pro terénní spektrometry
}

\author{
Kamila Johnová, Jaroslav Klusoň \\ Fakulta jaderná a fyzikálně inženýrská, ČVUT v Praze \\ kamila.johnova@fjfi.cvut.cz
}

Terénní spektrometry záření gama používané ke stanovení obsahu přírodních radionuklidů v horninách jsou v České republice kalibrovány pomocí pozemních standardů umístěných na kalibrační základně DIAMO s. p. ve Stráži pod Ralskem. Metodika kalibrace pomocí těchto standardů předpokládá nabrání celkem čtyř spekter po jednom na každém ze standardů. Ve stávajícím uspořádání jsou uživateli při kalibraci $\mathrm{k}$ dispozici údaje o obsahu př́irodních radionuklidů (K-40, U-238 a Th-232), které byly naměřeny certifikovaným spektrometrem na středech každého ze standardů.

$\mathrm{S}$ rozvíjejícími se technickými možnostmi a novými spektrometry, které přicházejí na trh se nabízí možnost rozšíření použitelnosti kalibračních standardů pro další typy kalibračních měření a kalibračních geometrií - zejména měření $\mathrm{v}$ různých místech základny, různých výškách apod. Pro tyto účely je třeba znát pole záření gama $\mathrm{v}$ celém vnitřním prostoru základny. V naší práci představíme výpočetní odhad pole dávkových příkonů záření gama od přírodních radionuklidů (K-40 a přeměnových řad U-238 a Th-232) uvnitř objektu stanovený výpočtem Monte Carlo. Náš výpočet využívá podrobný model kalibrační základny verifikovaný řadou měření realizovaných scintilačními i polovodičovými spektrometry. 


\section{Speciální případy měření za účelem stanovování efektivních dávek pracovníků na pracovištích s materiálem se zvýšeným obsahem přírodního radionuklidu}

\section{Eliška Fialová $^{1}$, Ivana Ženatá ${ }^{2}$, Petr Otáhal ${ }^{1}$, Jiří Sejkora ${ }^{3}$, Václav Trantina ${ }^{4}$, Dominika Kožešníková ${ }^{5}$}

${ }^{1}$ Státní ústav jaderné, chemické a biologické ochrany

${ }^{2}$ Státní úřad pro jadernou bezpečnost

3 Národní muzeum

${ }^{4}$ Hornické muzeum Příbram

${ }^{5}$ Muzeum Karlovy Vary

fialovaeliska@sujchbo.cz

Doporučení Státního úřadu pro jadernou bezpečnost „Stanovování osobních dávek pracovníků na pracovištích s materiálem se zvýšeným obsahem přírodního radionuklidu" z roku 2018 popisuje postupy měření a stanovování efektivních dávek pracovníků na pracovištích definovaných dle $\S 93$ odst. 1 písm. b) zákona č. 263/2016 Sb., atomový zákon, ve znění pozdějších předpisů. V § 87 vyhlášky č. 422/2016 Sb., o zajištění radiační ochrany a zabezpečení radionuklidového zdroje jsou $\mathrm{v}$ písm. a) až s) definované činnosti, které zařazují pracoviště jako tzv. pracoviště typu NORM (Naturally Occurring Radioactive Material).
V některých případech je z důvodu specifického režimu uživání pracoviště nezbytné přistoupit ke speciálnímu přístupu měření za účelem zpřesnění stanovení efektivních dávek pracovníků na pracovišti. Př́́kladem jsou depozitáře hornin a minerálů s vysokým obsahem přírodních radionuklidů zařazené dle $\S 87$ písm. p) vyhl. č. 422/2016 Sb. Příkon prostorového dávkového ekvivalentu (PPDE) je v různých místech pracoviště značně variabilní a dobu pobytu pracovníků u jednotlivých exponátů nelze přesně definovat. Užití průměrné hodnoty PPDE na pracovišti pro výpočet efektivní dávky ze zevního ozáření by mohlo vést ke značné nepřesnosti stanovení celkové efektivní dávky. 


\section{Out-of-field doses in pediatric photon and proton radiotherapy - Summary of the EURADOS WG9 activity}

\section{Željka Knežević}

Institut Ruđer Bošković, Zagreb, Croatia

zknez@irb.hr

The EURADOS Working Group 9 (Radiation Dosimetry in Radiotherapy) is engaged in a measurement campaigns designed to investigate secondary radiation doses inside a paediatric anthropomorphic phantom exposed to scanning proton radiotherapy and also to different photon radiotherapy modalities. The main goals were as to analyse and compare organ doses from secondary neutron and gamma radiation fields inside child anthropomorphic phantoms with different types of solid state detectors. The results were compared with measured secondary doses during different photon therapy modalities for similar case of brain treatment in children. In the presentaion the summary of the experiments and main findings will be shown. 


\title{
Dávky mimo cílový objem při protonové terapii: Experiment EURADOS WG9 - příprava Monte Carlo simulací a první výsledky
}

\author{
Jan Štika ${ }^{1}$, Marie Davídková ${ }^{\text {, Iva Ambrožová }}{ }^{2}$, Anna Jelinek \\ Michaelidesova, Jaroslav Klusoň ${ }^{1}$ \\ ${ }^{1}$ KDAIZ FJFI ČVUT v Praze \\ 2 ODZ, Ústav jaderné fyziky AV ČR, v.v.i.
}

jan.stika@post.cz

$\mathrm{V}$ radioterapii jsou dávky mimo cílový objem nežádoucí a pro správnou léčbu je vhodné znát spektra rozptýlených částic. Skupinou spolupracujících evropských institucí EURADOS WG9 byl v protonových centrech v Trentu a Krakově proveden experiment pro 3D zmapování dávek mimo cílový objem za použití terapeutického protonového tužkového svazku ve vodním fantomu o velikosti $300 \times$ $300 \times 600 \mathrm{~mm}^{3}$. Absorbovaná dávka byla měřena termoluminiscenčními detektory (TLD): MTS-7 ( $\left.{ }^{7} \mathrm{LiF}: \mathrm{Mg}, \mathrm{Ti}\right)$, MTS-6 ( $\left.{ }^{6} \mathrm{LiF}: \mathrm{Mg}, \mathrm{Ti}\right), \quad \mathrm{MTS}-\mathrm{N}$ (natLiF:Mg,Ti) a TLD700 ( $\left.{ }^{7} \mathrm{LiF}: \mathrm{Mg}, \mathrm{Ti}\right)$, radiofotoluminiscenčními detektory (RPL): GD-352M a GD-302M, a stopo- vými detektory $\mathrm{v}$ pevné fázi HARZLAS TD-1 $\left(\mathrm{C}_{12} \mathrm{H}_{18} \mathrm{O}_{7}\right)$ (Stolarczyk L. et al. Phys. Med. Biol. 2018 63(8): 085017).

Pro porozumění experimentálním výsledkům byly provedeny Monte Carlo simulace. Tyto simulace by za použití běžného osobního počítače trvaly několik týdnů. Z tohoto důvodu byly Monte Carlo simulace kódem FLUKA provedeny na výpočetních clusterech Národní gridové iniciativy METACENTRUM sdružení CESNET. Vypočteny byly absorbované dávky, příspěvky absorbovaných dávek od nejčastějších částic, LET a energetická spektra a tyto výsledky byly porovnány s experimentálně naměřenými daty. 


\title{
Specifika radioterapie elektronovým svazkem v Nemocnici České Budějovice a.s.
}

\author{
Eva Stýblová, Petra Jiříková, Zuzana Freitinger-Skalická \\ Zdravotně sociální fakulta JČU \\ styblova.eva@gmail.com
}

Úvod: Radioterapie elektronovým svazkem je jednou $\mathrm{z}$ léčebných modalit $\mathrm{v}$ radioterapii. Ozařování svazkem urychlených elektronů má v ozařování onkologických onemocnění minoritní, ale stabilní postavení. Radioterapii elektronovým svazkem lze použít samostatně nebo $\mathrm{v}$ kombinaci s fotonovým svazkem. Příkladem je léčba karcinomu prsu urychlenými fotony, kdy se následně může použít elektronový svazek pro cílené ozáření původního lůžka tumoru formou tzv. boostu. Předložený text se zabývá dozimetrickou kontrolou kvality elektronového svazku na Onkologickém oddělení Nemocnice České Budějovice, a.s. Jedná se o kontrolu dávky na kưži pacienta během ozařování s použitím přístroje pro in-vivo dozimetrii. Změřená dávka pomocí invivo dozimetrie byla následně porovnána s referenční dávkou z plánovacího systému. Odchylka změřené dávky od dávky referenční by neměla přesahovat toleranční hodnotu $\pm 7 \%$.

Metodika: Cílem studie bylo porovnat odchylky v měření dávek pomocí in-vivo dozimetrie $\mathrm{u}$ pacientek $\mathrm{s}$ karcinomem prsu ve dvou stanovených časových obdobích. Jako reprezentativní vzorek byl vybrán rok 2010 a 2019 . Byly zvoleny 2 soubory po 60 náhodně vybraných pacientkách léčených pro karcinom prsu, které postoupily ozáření technikou elektronového boostu, a byla u nich měřena dávka pomocí in-vivo dozimetrie. Tyto výběrové soubory celkem 120 pacientek pak byly mezi sebou statisticky porovnány. Data byla získána z počítačové databáze Onkologického oddělení Nemocnice České Budějovice a.s.

Závěr: Z výsledků statistického šetření vyplynulo, že průměrná odchylka změřené dávky od dávky referenční z plánovacího systému byla v roce 2019 o 1,7 \% vyšší než průměrná odchylka v roce 2010. Dále bylo prokázáno, že ani v jednom sledovaném roce se nevyskytla nulová odchylka měření, což znamená, že četnost měřených odchylek byla v obou letech stejná. 


\title{
Porovnanie $250 \mathrm{MeV}$ protónového cyklotrónu so synchrotrónom pri rádioterapii očnej šošovky
}

\author{
Andrea Šagátová ${ }^{1}$, Igor Gomola ${ }^{2}$, Marko Fülöp ${ }^{3}$, Pavol Ragan ${ }^{3}$, \\ L'ubica Foltínová ${ }^{4}$ \\ 1 Slovenská technická univerzita v Bratislave, FEI, ÚJFI \\ ${ }^{2}$ Slovenská zdravotnícka univerzita v Bratislave, FVZ \\ ${ }^{3}$ ABRS s.r.o. \\ ${ }^{4}$ Ekonomická univerzita v Bratislave \\ marko.fulop@gmail.com
}

Pri relatívne väčších rozmeroch nádorového tkaniva na očnej šošovke sa na rádioterapeutický zákrok využívajú zväzky protónov s energiou 60 až $65 \mathrm{MeV}$. Očná šošovka má hrúbku asi $4 \mathrm{~mm}$ a je potrebné, aby nádorové tkanivo bolo selektívne ožiarené, a teda nebolo významnejšie radiačne zatažené okolité zdravé tkanivo.

Častým zdrojom protónového zväzku v rádioterapii býva cyklotrón urýchlujúci protóny na stabilnú energiu (bežne 230 až $250 \mathrm{MeV}$ ), ktorá sa pomocou filtrov degraduje na nižšiu požadovanú energiu. Na tento účel sa tiež využíva synchrotrónový urýchlovač, ktorý na rozdiel od cyklotrónového urýchluje protóny priamo na požadovanú energiu.

V prezentácii sa pomocou Monte Carlo simulácií Braggových píkov zväzkov protónov porovnáva ožiarenie očnej šošovky a zdravého tkaniva $\mathrm{v}$ jej okolí pri rádioterapii pomocou $250 \mathrm{MeV}$ cyklotrónového urýchlovača a synchrotrónu.

Ukázalo sa, že pri znížení energie cyklotrónového zväzku protónov z $250 \mathrm{MeV}$ na $60 \mathrm{MeV}$ pomocou filtrov z materiálov ekvivalentných vode dochádza k rozšíreniu Braggovho píku presahujúceho do ožiarenia zdravého tkaniva $v$ okolí očnej šošovky až do híbky cca $3 \mathrm{~mm}$. V porovnaní so synchrotrónom, na ožiarenie očnej šošovky rovnakou terapeutickou dávkou pomocou $60 \mathrm{MeV}$ protónov, je pri použití $250 \mathrm{MeV}$ cyklotrónu v dôsledku degradácie energie filtrami, 8 násobne nižšia účinnost ožarovania očnej šošovky. Túto skutočnost je potrebné zohladnit pri opatreniach zabezpečenia radiačnej ochrany prevádzky protónového urýchlovača. Na druhej strane, v porovnaní so synchrotrónmi, cyklotróny produkujú intenzívnejšie zväzky urýchlených protónov, čo vedie $\mathrm{k}$ skráteniu doby ožiarenia pacienta. 


\section{Radiační ochrana pacientů a personálu a prevence vzniku radiačních mimořádných událostí s aplikací na Oddělení nukleární medicíny Nemocnice České Budějovice, a. s.}

\section{Zuzana Freitinger-Skalická ${ }^{1}$, Kristína Daňová ${ }^{2}$, Vojtěch Kratochvíl ${ }^{2}$, Ladislav Šabata ${ }^{1}$}

${ }^{1}$ Zdravotně sociální fakulta JU

2 Nemocnice České Budějovice, a.s.

skalicka@zsf.jcu.cz

Současný stav: Nukleární medicína se zabývá diagnostikou a terapií za pomoci otevřených radioaktivních zářičů, které jsou aplikovány do vnitřrního prostředí organismu. Téměř vždy je práce na oddělení nukleární medicíny spojena s rizikem ozáření personálu, zejména při manipulaci s radiofarmakem a podávání pacientovi. Pro nepřekračování stanovených limitů na pracovištích nukleární medicíny je stanovena celá řada opatření. K dosažení cíle radiační ochrany je třeba u personálu pracujícího se zdroji ionizujícího záření zásadně dodržet ochranu před zevním, ale i vnitřním ozářením.

Metodika: Na všech úsecích oddělení nukleární medicíny je potřebné monitorovat př́ḱkon dávkového ekvivalentu, povrchovou aktivitu a objemovou aktivitu ve vzduchu. Vznik konkrétních radiačních mimořádných událostí na pracovišti ONM NČB a analýza jejich př́čin odhalila nedostatky v procesu a absenci bezpečnostních prvků žádoucích při skladování radioaktivního kapalného odpadu pocházejícího z ONM. Pomocí SWOT analýzy byly vyhodnoceny faktory, které by mohly ovlivnit optimalizaci radiační ochrany na
ONM. Vnitřní prostředí tvořily silné a slabé stránky, pro které byly zvoleny faktory, které mohly ovlivnit radiační ochranu na oddělení. Naopak př́ležitosti a hrozby byly faktory, které působily z vnějšího okolí.

Výsledky: V Nemocnici České Budějovice a.s. je velmi dobrá úroveň radiační ochrany. Jak u pracovníků ambulantní části, tak i té lůžkové. Radiační limity nikdy nepřekročily povolenou mez. Dávky tvoří nejvíce $1 / 25$ limitů u celotělového TLD a méně než $1 / 10$ limitů u prstového TLD. Je zřejmé, že se zde př́ísně dodržují všechny principy a způsoby radiační ochrany. U radiačních pracovníků se dbá na ochranná opatření před vnější i před vnitřní kontaminací radionuklidy. Di̊vodem optimální radiační ochrany je i skutečnost, že při všech činnostech na ONM dochází k častému střídání pracovníků. Proto žádný ze zaměstnanců neměl hodnoty efektivní a ekvivalentní dávky zřetelně větší než ostatní.

Závěr: Po vyhodnocení dat a SWOT analýzy lze konstatovat, že radiační ochrana pacientů a personálu na oddělení nukleární medicíny v Nemocnici České Budějovice, a.s. je dostatečně 
optimalizována. Přínos v oboru nukleární medicíny je nepochybný. Nabídka vyšetření a léčebných postupo̊ je velmi rozmanitá a podložená letitými zkušenostmi. 


\title{
Diagnostické referenčné úrovne v skríningovej mamografii na Slovensku
}

\author{
Dušan Šalát ${ }^{1}$, Denisa Nikodemova \\ ${ }^{1}$ FZV UCM Trnava \\ salat@uro.sk
}

Medzi základné princípy radiačnej ochrany patrí odôvodnenie, optimalizácia a limitovanie ožiarenia. Nakolko pri lekárskom ožiarení pacientov limity neexistujú a pri skríningovej mamografii je indikovanie takéhoto vyšetrenia odôvodnené celospoločenským záujmom pri prevencii onkologických ochorení asymptomatických pacientov, ostáva najdôležitejším nástrojom radiačnej ochrany optimalizácia. V procese optimalizácie hladáme vyvážený vztah medzi kvalitou zobrazenia a velkostou dávky na pacienta. Kvalita zobrazenia v mamografii je vizuálne hodnotená napr. pri skúškach prevádzkovej stálosti pomocou akreditačných fantómov obsahujúcich mikrokalcifikáty, tumory a fibrily rôznych velkostí. Z pohladu ožiarenia pacienta je základným indikátorom správnej optimalizácie neprekročenie diagnostickej referenčnej úrovne (DRÚ) zverejnenej v opatrení Ministerstva zdravotníctva Slovenskej republiky (MZ SR) z 19. marca 2018 č. S02933-2018-OL, ktorým sa ustanovujú diagnostické referenčné úrovne lekárskeho ožiarenia. V prípade mamografických vyšetrení je DRÚ vyjadrená ako priemerná dávka v mliečnej žlaze, v závislosti od hrúbky komprimovaného prsníka. Trvalé prekračovanie DRÚ je neprípustné a v niektorých prípadoch je považované za neplánované lekárske ožiarenie pacienta.

$\mathrm{V}$ našej práci sme analyzovali dodržiavanie diagnostických referenčných úrovní za rok 2020 u 16 mamografických pracovísk posúdených dočasnou odbornou pracovnou skupinou, ktoré komisia MZ SR pre zabezpečenie kvality v rádiodiagnostike, radiačnej onkológii a v nukleárnej medicíne odporučila zaradit do mamografického skríningu a ktoré sú uverejnené na webovej stránke MZ SR. Nakolko uvedené pracoviská používajú automatizovaný systém na sledovanie ožiarenia pacientov DQC monitor (Dose Quality Control), analýza dát bola realizovaná pomocou tohoto systému pre všetky expozície (252 168) vykonané na uvedených mamografických pracoviskách od 1.1.2020 do 31.12.2020.

Okrem hodnotenia ožiarenia pacientov a dodržiavania diagnostických referenčných úrovní sme analyzovali pomocou tohoto systému aj obrazovú kvalitu pri vykonávaní skúšok prevádzkovej stálosti pomocou mamografického akreditačného fantomu, ktorý sa vykonáva $\mathrm{v}$ pravidelných intervaloch.

Výsledky analýz budeme prezentovat $\mathrm{v}$ našom príspevku. 


\section{Prehl'ad počtu vykonaných vyšetrení $v$ jednotlivých rádiodiagnostických modalitách na Slovensku, v rokoch 2019-2020}

\section{Anita Zubáková ${ }^{1}$, Karol Böhm ${ }^{2}$, Dušan Šalát ${ }^{3}$, Denisa Nikodemová ${ }^{4}$}

${ }^{1}$ Odbor radiačnej ochrany, Úrad verejného zdravotníctva Slovenskej republiky, Katedra verejného zdravotníctva, SZU Bratislava,

2 Odbor radiačnej ochrany, Úrad verejného zdravotníctva Slovenskej republiky

${ }^{3}$ Fakulta zdravotníckych vied, Univerzita sv. Cyrila a Metoda

${ }^{4}$ Radiačná hygiena, SZU Bratislava

anita.zubakova@uvzsr.sk

Vzhladom na dynamický rozvoj využívania zdrojov ionizujúceho žiarenia v zdravotníctve, ako aj nových metód RTG vyšetrení, neustále narastá počet vyšetrovaných pacientov, a tým aj radiačná zátaž obyvatelov. $\mathrm{Z}$ tohto dôvodu je nevyhnutné lekárske ožiarenia obmedzovat prostredníctvom dôslednejšieho odôvodnenia vyšetrení. Tento odborný príspevok poskytuje prehlad spracovaných dát zhromaždených zo všetkých dostupných zdrojov na území Slovenskej republiky, so zvláštnym dôrazom na narastajúci počet vyšetrení počítačovou tomografiou. Spracované dáta odrážajú aktuálnu epidemiologickú situáciu, nakolko za rok 2020 počet vyšetrení klesol až o 721143 . Najčastejšie aplikovaným vyšetrením spájaným s traumatizujúcou udalostou bolo RTG vyšetrenie - Lebka prehladne v dvoch rovinách, ktorého počet v roku 2019 tvorilo až 187228 výkonov a v roku 2020 nastal zretelný pokles v počte vyšetrení na úroveň 122951. Dôležité údaje sú pozorované aj v oblasti mamografického skríningu. Počet vyšetrení - Mamografia bilaterálna bol v roku 2019 na úrovni 275191 a v roku
2020 sa danému vyšetreniu podrobilo len 227707 pacientok. V poslednej dobe rastie počet mužov, ktorí podstupujú mamografické vyšetrenie - v roku 2019 v počte 435 a v roku 2020 absolvovalo toto vyšetrenie iba 319 pacientov. Z dôvodu potenciálneho zdravotného rizika je dôležité, aby indikujúci lekár bol schopný odôvodnit príčinu aplikácie počítačovej tomografie, najmä u pacientov mladších vekových kategórií a žien vo fertilnom veku, s ohladom na odlišné účinky ionizujúceho žiarenia na mladý organizmus v dobe jeho vývinu. Z údajov za roky 2015 - 2020 dostupných z dát jednotlivých poistovní vyplýva, že aplikácia výpočtovej tomografie v oblasti diagnostiky má stúpajúcu tendenciu. Podla najnovších údajov OECD sa vo svete využíva cca. 30 CT prístrojov na 1 milión obyvatelov, čo predstavuje v priebehu posledných 10 rokov nárast o viac ako $43 \%$. Počas tohto obdobia stúpol v Slovenskej republike počet využívaných CT prístrojov z roku 2015 z 90 na 147 CT prístrojov v roku 2020, čo je nárast o 32,49\%, z čoho vyplýva aj nárast uskutočňovaných RTG vyšetrení. V roku 2020 sa 
vykonalo v Slovenskej republike 605531 CT vyšetrení, čo predstavuje nárast o približne $20 \%$ počtu CT vyšetrení za posledných 5 rokov. Napriek skutočnosti, že je vo viacerých medicínskych oblastiach nahradená magnetickou rezonanciou, indikujúci lekári stále vo vel'kej miere používajú ako prvú vol'bu na určenie diagnózy práve vyšetrenia počítačovou tomografiou. 


\title{
Príspevok k medzinárodnej diskusii o revízii a zjednodušení systému radiačnej ochrany
}

\author{
Denisa Nikodemova $^{\text {None }}$, Dušan Šalát ${ }^{1}$ \\ ${ }^{1}$ Ústav radiačnej ochrany s.r. o. \\ denisa.nikodemova@gmail.com
}

Posledná rozsiahla revízia systému radiačnej ochrany bola publikovaná pred 14-mi rokmi (ICRP 103, 2007) a v mnohých oblastiach a definíciách vyžaduje inováciu, zjednodušenie a zapracovanie zmien vyplývajúcich z praktickej aplikácie zdrojov ionizujúceho žiarenia, ako aj z výsledkov výskumu, získaných v priebehu posledných rokov. Medzinárodná Asociácia pre Rádiologickú Ochranu (IRPA) pripravila základný dokument venovaný rozboru potrebných zmien pre udržanie systému radiačnej ochrany do budúcnosti a pre získanie harmonizácie a objektivizácie úrovne ochrany ludí a životného pro- stredia pred nepriaznivými účinkami žiarenia, bez prílišného obmedzovania prínosu aplikácie tohto ožiarenia a dynamického rozvoja vo všetkých oblastiach činností. V prezentácii predložíme niektoré návrhy revízie na diskusiu, a to predovšetkým v oblasti aplikácie ionizujúceho žiarenia v medicíne, synchronizácie operačných veličín pre určenie absorbovaných a ekvivalentných dávok, využitia efektívnej dávky a klasifikácie zdravotných účinkov žiarenia pre hodnotenie rizika z ožiarenia a jeho možné porovnanie s inými rizikovými činnostami. 


\title{
Optimalizácia vyšetrovacích CT protokolov u obéznych pacientov pomocou zostrojeného antropomorfného fantómu
}

\author{
Zdenka Balogová ${ }^{1}$, Lucie Súkupová ${ }^{2}$ \\ 1 Nemocnice Na Homolce \\ ${ }^{2}$ Institut klinické a experimentální medicíny \\ zdenka.balogova@homolka.cz
}

Obezita ovplyvňuje zdravotnú starostlivost vo viacerých smeroch a jedným z nich je aj rádiodiagnostika. CT vyšetrenia bariatrických pacientov sú častejšie ako v minulosti a nadpriemerná hmotnost týchto pacientov má vplyv na priebeh aj výsledok CT vyšetrenia. CT obrazy majú horšiu kvalitu a môžu obsahovat artefakty, ktoré sa u referenčných pacientov nevyskytujú. Práca sa zaoberá optimalizáciou vyšetrovacích CT protokolov u obéznych pacientov. Dostupné CT protokoly sú hodnotené a porovnávané z hladiska kvality obrazu, dávky pacientovi, času skenovania a na základe výsledkov je vybraný najvhodnejší protokol pre dva CT prístroje výrobcu Siemens. Na optimalizáciu bol použitý antropomorfný fantóm brušnej dutiny s rozširujúcim prstencom simulujúcim tuk. Antropomorfný fantóm bol zostrojený pomocou 3D tlače na základe $\mathrm{CT}$ dát reálnych pacientov. Všetky orgány a tkanivá boli vyrobené z tkanivovo - ekvivalentných materiálov, ktoré svojím zoslabením vhodne simulujú dané orgány. 


\title{
Nevyhnutnost' spätnej väzby pri sledovaní dávky žiarenia obdržanej pacientom pri lekárskych expozíciách.
}

\author{
Martina Horváthová ${ }^{1}$, Zuzana Bárdyová ${ }^{2}$, Igor Gomola ${ }^{3}$ \\ 1 Trnavská univerzita FZaSP \\ 2 Trnavská univerzita v Trnave \\ ${ }^{3} \mathrm{SZU}$
}

martina.horvathova@truni.sk

Sledovanie radiačnej zátaže pacienta poskytuje informácie, ktoré môžu zabránit jeho dalšiemu rádiologickému vyšetreniu. Tu sa dostávame k otázke ako zabránit „zbytočnému“ vyšetreniu a dosiahnut, aby záznam o vyšetrení pacienta, jeho výsledku a radiačnej zátaži bol dostupný všetkým zdravotníckym zriadeniam v rámci celej krajiny.

Väčšina zdravotníckych zariadení v SR archivuje snímky a parametre vyšetrenia vrátane dávok obdržaných pacientom v systéme PACS (Picture archiving and communicating system). V rámci jedného zdravotníckeho zariadenia by teda nemal byt problém získat informáciu o radiačnej zátaži pacienta zo všetkých vyšetrení realizovaných $\mathrm{v}$ tomto zariadení. Nevýhodou systému je, že nemožno využit vzdialený prístup, čo prestavuje problém, pri odovzdávaní informácie do iného zdravotníckeho zariadenia. Rovnako z pohladu radiačnej ochrany je nevýhodou systému, že umožňuje rádiologickému technikovi, ktorý údaje do systému zadáva, pokračovat $\mathrm{v}$ archivácii bez toho, aby zadal všetky údaje. Pokial sa tam nenachádzajú všetky parametre pre výpočet dávky, alebo rizika z ožiarenia (napr. antropologické faktory pacienta), nie je možné takýto záznam použit pre spätné overenie velkosti expozície pacienta, či navrhovat metódy optimalizácie vyšetrenia.

Okrem systému PACS využíva množstvo rádiologických pracovísk nový archivačný systém DQC (Dose Quality Control) monitor, ktorý čerpá údaje z PACSu a nahrádza a zároveň dopĺña doterajšie integrované systémy. Hlavným rozdielom systémov je, že DQC monitor poskytuje aj údaj o velkosti efektívnej dávky a upozorňuje lekára, či rádiologického asistenta na prekročenie diagnostických referenčných úrovní (DRÚ). Hoci v súčasnosti má väčšina slovenských rádiologických oddelení DQC monitor nainštalovaný, jednotlivé systémy ale nie sú zosietované a pracoviská nevyužívajú všetky rozhrania systému. Zamestnanci konkrétneho pracoviska môžu vidiet len pacienta, ktorého osnímkovali v rámci svojho pracoviska, ale nevedia si vyhladat jeho expozície z iných rádiologických pracovísk. Ako už bolo spomenuté, DQC monitor síce upozorní pracovisko na prekračovanie DRÚ, neposkytuje ale principiálne riešenie na odstránenie problému a pracovníci tento fakt často ignorujú. 
Cielom príspevku je vyvolat disku- sledovanie dodržiavania DRÚ, pomôct siu, akým spôsobom zabezpečit spätnú pri optimalizácii štandardov a poskytväzbu pre pracovníkov rádiologických nút aj možnost dozimetrickej spätnej oddelení, a tým im ulahčit priebežné väzby. 


\title{
Faktory spôsobujúce bias pri hodnotení efektívnej dávky $z$ výpočtovej tomografie srdca a koronárnych ciev
}

\author{
Zuzana Bárdyová ${ }^{1}$, Martina Horváthová ${ }^{2}$, Igor Gomola ${ }^{3}$ \\ 1 Trnavská univerzita v Trnave \\ 2 Trnavská univerzita FZaSP \\ $3 \mathrm{SZU}$ \\ zuzanabardyova@gmail.com
}

Efektívna dávka predstavuje štandardne využívanú veličinu, ktorá odráža relatívne riziko vyplývajúce $\mathrm{z}$ vystavenia sa ionizujúcemu žiareniu. Jednou z najjednoduchších a najčastejšie využívaných metód na odhad efektívnej dávky z výpočtovej tomografie (CT) je súčin DLP (súčin dávky a dížky) a konverzného koeficientu (k-faktor). Hodnoty k-faktora sú stanovené pre CT rôznych anatomických oblastí, t.j. hlava, hlava a krk, krk, hrudník, brušná dutina, panva a hrudník-brušná dutinapanva. K-faktor pre anatomickú oblast' srdca a koronárnych ciev však absentuje a využíva sa k-faktor pre oblast hrudníka.

Ako už bolo spomenuté vo viacerých štúdiách, efektívna dávka využívajúca k-faktor stanovený pre CT hrudníka nemusí predstavovat skutočný odhad efektívnej dávky vyplývajúcej z CT srdca a koronárnych ciev. Taktiež autori niektorých štúdií konštatovali, že využívanie $\mathrm{k}$-faktora $0,014 \mathrm{mSv} \mathrm{mGy}^{-1} \mathrm{~cm}^{-1}$, ktorý je stanovený pre oblast hrudníka, spôsobuje podhodnotenie efektívnej dávky pochádzajúcej z CT koronarografie (CCTA). Práve z dôvodu, že CT srdca a koronárnych ciev predstavuje čoraz častejšie diagnostické vyšet- renie v kardiológii, bolo by vhodné stanovenie k-faktora konkrétne pre túto anatomickú oblast.

Kedže hodnotením efektívnej dávky z CCTA sa zaoberalo velké množstvo štúdií, na prvý pohlad ide o lahko porovnatelné údaje. Jedným z problémov však je, že v štúdiách sa môžeme stretnút s rôznymi typmi metodík, napr. rozličné dozimetrické softvéry alebo hodnoty k-faktora. Nejednotnost metodík výpočtu efektívnej dávky môže pri jej porovnávaní spôsobit skreslenie o viac ako $30 \%$. Z tohto dôvodu ide o jeden z najdôležitejších faktorov, ktorý je potrebné vždy zohladnit. Okrem iného sa pri porovnávaní hodnôt efektívnej dávky z CCTA zabúda aj na dalšie faktory. Práve technika skenovania, pohlavie, tepová frekvencia a BMI sú faktory, ktoré $\mathrm{v}$ mnohých prípadoch pri porovnávaní efektívnej dávky zostávajú nepovšimnuté.

Taktiež je dôležité poznamenat, že neodmyslitelnou súčastou CCTA je vyhotovenie topogramu, ako aj vyšetrenie kalciového skóre, z čoho vyplýva, že efektívna dávka z CCTA by mala zahŕňat dávku ionizujúceho žiarenia pochádzajúcu zo všetkých sekvencií vyšetrenia. 


\section{D zobrazovanie pomocou CBCT (cone-beam počítačová tomografia), v stomatológii}

\section{Anita Zubáková ${ }^{1}$, Denisa Nikodemová ${ }^{2}$, Igor Gomola ${ }^{2}$, Andrej Galbavý ${ }^{3}$}

${ }^{1}$ Odbor radiačnej ochrany Úrad verejného zdravotníctva Slovenskej republiky, Katedra verejného zdravotníctva, SZU Bratislava

${ }^{2}$ Radiačná hygiena, SZU Bratislava

3 Odbor radiačnej ochrany Úrad verejného zdravotníctva SR

anita.zubakova@uvzsr.sk

Výsledkom rýchleho technologického vývoja a inovácií v poslednom období sú aj tzv. zariadenia cone-beam počítačovej tomografie (CBCT), ktorých hlavným princípom je vytvorenie 3D obrazu s využitím kuželového zväzku žiarenia. Význam CBCT spočíva vo vysokej presnosti v porovnaní s ostatnými zobrazovacími metódami. Hlavnou diskutovanou otázkou CBCT je vztah medzi prínosom jeho využívania v oblasti stomatológie a potenciálnym rizikom pre pacienta a obsluhujúci personál. Pre optimalizáciu podmienok zobrazovania je dôležité porozumiet vztahu medzi diagnostickým výstupom RTG zobrazovacieho procesu a jeho fyzikálnymi a technickými charakteristikami. Najefektívnejšie využitie ionizujúceho žiarenia je, ked predpokladaný prínos pre osobu alebo pre spoločnost prevažuje nad zdravotnou ujmou, ktorú môže táto činnost spôsobit pri získaní vyhovujúcej diagnostickej informácie s najmenšou možnou dávkou pre pacienta. Neodmyslitelnou súčastou radiačnej ochrany je prehíbenie vedomostí o velkosti aplikovanej dávky žiarenia, ktorá neprekračuje predpísané diagnostické referenčné úrovne.
Optimálne podmienky ožiarenia a optimálny výber fyzikálnych a technických parametrov pre nové digitálne zobrazovacie metódy sa môžu významne líšit od postupov platných pre konvenčné zobrazovanie. Separovanie vytvárania zobrazenia od jeho prezentácie, ktoré je možné pri použití digitálnej zobrazovacej techniky, dovoluje nezávislú optimalizáciu týchto dvoch stupňov zobrazovacieho procesu. Cielom pripravovanej štúdie je prijatie opatrení na opodstatnenost a odôvodnenie činnosti vedúcej k ožiareniu v oblasti radiačnej ochrany, hlavne u detskej populácie v stomatológii a vypracovanie usmernenia pre optimálne ožiarenie pri rôznych vyšetrovacích postupoch s využitím CBCT. $\mathrm{Na}$ základe výsledkov merania budú porovnávané najvýznamnejšie vyšetrenia CBCT s konvenčnými metódami za vytvorenia podmienky pre ustanovenie nových diagnostických referenčných úrovní pre stomatologické CBCT prístroje. Pre optimalizáciu velkosti ožiarenia je potrebné nastavit najvhodnejšie field of view (FOV) a parametre ožiarenia pre získanie najlepšej diagnostickej informácie. Súčastou bude aj posúdenie možnosti zavedenia opatrení na 
používanie osobných ochranných pros- kosti ožiarenia v jednotlivých vekových triedkov u pacienta ako aj u personálu kategóriách a predpokladanej indikácie na zabezpečenie ochrany kritických or- CBCT vyšetrení v praxi.

gánov. Štúdia bude rozdelená podla vel- 


\title{
Vliv kovových implantátů na kvalitu CT obrazů a na automatickou modulaci proudu: fantomová studie
}

\author{
Hana Linhartová, Petr Libus \\ ONM, Nemocnice Havlíčkův Brod, p. o. \\ h.linhartova@tehuti.cz
}

\begin{abstract}
Automatické systémy pro modulaci proudu mohou významně snížit celkovou dávku z CT vyšetření při zachování stejné kvality obrazu v celé vyšetřované oblasti. $\mathrm{K}$ modulaci proudu využívají různí výrobci různé algoritmy a tyto systémy mohou být významně ovlivněny např́íklad prrítomností kovu ve vyšetřované oblasti a nebo projekcí lokalizačního skenu, který je použit pro plánování vyšetření.

V této práci je ukázáno chování automatické modulace proudu na přístroji Symbia Intevo Bold (firmy Siemens) při skenování fantomu, který simuluje lidskou pánev se dvěma kovovými kyčelními náhradami. Dále je porovnána kvalita CT obrazů, které byly získané za použití různých referenčních hod-

not proudu (a tedy i výsledné dávky) a byly zrekonstruované různými rekonstrukčními algoritmy s a bez použití algoritmu pro redukci kovových artefaktů.

Z výsledků studie vyplynulo, že pro správnou optimalizaci vyšetření je velice důležité porozumět chování automatické modulace proudu a rekonstrukčním algoritmům. Druh lokalizačního skenu a kov ve skenovaném objektu má velký vliv na automatickou modulaci proudu a může tedy i výrazně ovlivnit celkovou dávku z CT vyšetření. Zároveň se ukázalo, že CT obrazy rekonstruované s korekcí na artefakty z kovu získané při vyšších' hodnotách proudu nemusí vždy poskytovat výrazně lepší kvalitu obrazu.
\end{abstract}




\title{
Voxelový Monte Carlo model antropomorfního fantomu torza trupu „Elvis“
}

\author{
Jana Šmoldasová, Jaroslav Šolc, Vladimír Sochor \\ Český metrologický institut \\ jsmoldasova@cmi.cz
}

„Elvis“ je antropomorfní fantom torza trupu, který lze využít pro různé studie v nukleární medicíně, primárně pro oblast krku. V rámci projektu TAČR č. FW01010471 - ThyroPIX byl na základě tohoto fantomu vytvořen jeho voxelový Monte Carlo (MC) model. Účelem MC modelu je získat možnost testování a optimalizace rekonstrukčních algoritmů pro Comptonovu kameru, jejichž cílem je stanovení prostorové distribuce aktivity $\mathrm{v}$ těle pacienta, zde tedy konkrétně v oblasti krku.

Voxelový model fantomu sestává z mřížky, kdy každému elementu mř́ǐžky o objemu přibližně $1 \mathrm{~mm}^{3}$ je přiřazen určitý materiál. Tak lze docílit věrného napodobení komplikovaného tvaru fantomu. Celkem byly uvažovány 4 materiály: vzduch, plast ABS použitý k 3D tisku skořápky fantomu, polyuretan jako aproximace měkké tkáně vyplňující skořápku fantomu a materiál s vyšší hustotou a protonovým číslem aproximující páteř. Vložky s aktivitou, které jsou do reálného fantomu vkládány, jsou modelovány standardním způsobem pomocí geometrických ploch.
Validace MC modelu byla provedena porovnáním vypočítané a změřené píkové detekční účinnosti pro vybrané energie radionuklidu I-131, který byl ve fantomu prostorově rozložen $v$ přibližném, avšak velmi dobře známém místě a tvaru štítné žlázy. Porovnání bylo provedeno $\mathrm{v}$ pozicích před, za a pod fantomem. Relativní rozdíly píkových účinností se pohybovaly typicky do $\pm 3 \%$, přičemž celková nejistota porovnání je obvykle vyšší. Vzhledem ke skutečnosti, že do porovnání zasahuje mnoho faktorů, jako např́ílad homogenita materiálu fantomu, lze uvedené výsledky považovat za úspěšnou validaci voxelového modelu fantomu.

MC model fantomu „Elvis“ umožní testování rekonstrukčních algoritmů pro různá prostorová rozložení aktivity bez nutnosti provádět všechna měření na reálném fantomu.

Projekt FW01010471ThyroPIX gama kamera nové generace pro zobrazování štítné žlázy a malých orgánů pomocí metod nukleární medicíny je spolufinancován se státní podporou Technologické agentury ČR v rámci programu TREND 2019. 


\title{
Odhad externího ozáření personálu a rodinných př́slušníku pacientů po radionuklidové terapii pomocí Lu-177
}

\author{
Andrej Vondrák ${ }^{1}$, Jana Hudzietzová ${ }^{2}$, Marko Fülöp ${ }^{3}$, Jozef Sabol ${ }^{4}$, \\ Peter Nemček ${ }^{1}$ \\ ${ }^{1}$ IZOTOPCENTRUM, s.r. o. \\ ${ }^{2}$ FBMI ČVUT v Praze \\ ${ }^{3}$ ABRS,s.r.o. \\ ${ }^{4}$ Policejní akademie České republiky v Praze \\ marko.fulop@gmail.com
}

Radionuklidová terapie pomocí radiofarmak značených Lu-177 je v současné době standardní léčebnou metodou pro vybranou skupinu nádorů. Během terapie jsou vystaveni určitému externímu ozáření nejen pracovníci zajištující př́ípravu a podání radiofarmaka, ale i pracovníci podílející se na zabezpečení zdravotnické péče o naaplikovaného pacienta a rodinní příslušníci, kteř́ žijí ve stejné domácnosti s propuštěným pacientem. Dozimetrie léčeného pacienta je obtížná nejen z důvodu sběru potřebných dozimetrických dat pro konkrétního pacienta, ale i kvůli jejich interpretaci. Cílem příspěvku je odhadnout externí ozáření ošetřujících pracovníků na pracovišti nukleární medicíny a osob v domácnosti, kteří se podíleli na péči prvních pacientů po terapii pomocí radiofarmaka značeného Lu-177.

Na vybraném pracovišti podstoupilo od června 2021 do konce srpna 2021 celkem 12 pacientů terapii pomocí radiofarmaka značeného Lu-177 (sběr dat na daném pracovišti stále pokračuje). U osob, podílejících se na terapii pacienta byl sledován osobní dávkový ekvi- valent $H p(10)$ pomocí elektronického dozimetru, který byl umístěn na hrudi monitorovaných osob během jejich kontaktů s pacientem. Rodinní príslušníci byli monitorováni po dobu 1 týdne, přičemž odečet $\mathrm{z}$ dozimetru byl prováděn ráno.

$\mathrm{V}$ příspěvku jsou uvedeny některé předběžné výsledky monitorování zahrnující průměrnou radiační zátěž ve smyslu Hp(10) stanovenou pomocí elektronického dozimetru u osob, které doprovázely pacienta na terapii a následná vyšetření. Z hlediska osob, které pečovaly o pacienta týden po terapii, byl odhadnut týdenní $\mathrm{Hp}(10)$. Též byly v období únor 2020 až září 2021 porovnány průměrné hodnoty $\mathrm{Hp}(10) \mathrm{u}$ pracovníků, kteří se podíleli na terapii pacienta. Mezi sledovanými profesemi byly zjištěny rozdílné hodnoty ozáření, které souvisely s pracovní náplní pracovníka $\mathrm{v}$ př́tomnosti naaplikovaného pacienta. Zdravotní sestra, která se v průběhu terapie starala o pacienta, patřila mezi profese s největšími naměřenými hodnotami $\operatorname{Hp}(10)$. Tato měření stále pokračují. 
Ukazuje se, že na zkoumaném pracovišti nukleární medicíny nemělo zavedení terapie pomocí Lu-177 významný vliv na velikost ročního osobního dávkového ekvivalentu $\mathrm{Hp}(10)$ sledovaných pracovníků oproti předchozím rokům, kdy se toto radiofarmakum nepouží- valo. $\mathrm{V}$ příspěvku budou prezentovány předběžné výsledky $H p(10)$ vybraných skupin, pomocí kterých může být optimalizována radiační ochrana pracovníků i rodinných příslušníků po podání terapie pomoci Lu-177. 


\title{
Je český radiologický fyzik evropským radiologickým fyzikem?
}

\author{
Irena Koniarová \\ FJFI ČVUT v Praze \\ irena.koniarova@fjfi.cvut.cz
}

\begin{abstract}
Profese radiologického fyzika je pro ob- vání radiologických fyziků, udělit certilast lékařského ozáření klíčová. Radio- fikát, který zaručuje, že tyto programy logický fyzik musí projít adekvátním jsou v souladu se současnými evropvzděláváním a následným specializač- skými požadavky. Přednáška popisuje ním výcvikem. Evropská komise vydala český systém vzdělávání radiologických v roce 2014 dokument, který má napo- fyziků v porovnání s ostatními členmoci tyto postupy v jednotlivých člen- skými zeměmi a pokusí se odpovědět na ských zemích harmonizovat. EFOMP otázku, zda lze českého radiologického (European Federation of Organisations fyzika pokládat za evropského radiofor Medical Physics) může zemím, které logického fyzika.
\end{abstract}

předloží národní program pro vzdělá- 


\title{
Pregraduální a postgraduální vzdělávaní radiologických asistentů v České republice a v rámci EU
}

\author{
Zuzana Freitinger-Skalická, Štěpán Kavan, Renata Havránková
}

\author{
Zdravotně sociální fakulta JU \\ skalicka@zsf.jcu.cz
}

Cílem studijního programu Radiologická asistence je získání odborné způsobilosti k výkonu povolání Radiologický asistent (RAD), který je schopen vykonávat díky odborné kvalifikaci své povolání bez odborného dohledu. Studijní program musí být v souladu se současnými odbornými studijními programy zemí Evropské unie a odpovídat základním principům pro vzdělání pracovníků ve zdravotnictví.

$\mathrm{V}$ návaznosti na Boloňskou deklaraci jde o kompatibilní vzdělávání se zeměmi EU. Zaměřujeme se na celkový přehled o vzniku organizací sdružujících radiologické asistenty a radiology až k současné SRLA, o její spolupráci s organizacemi EFRS (European Federation of Radiographer Societies) a ISRRT (International Society of Radiographers and Radiological Medical Technologists) a o různých úrovních spolupráce $\mathrm{v}$ tomto oboru a uplatnění $\mathrm{v}$ praxi.

Příspěvek se zaměřuje na vzdělávání radiologických asistentů $\mathrm{v}$ minulosti, současnosti a v době distanční výuky. Vzdělávání RAD je složitý proces sestávající z učení nebo získávání znalostí, dovedností, hodnot, praktických dovedností, morálky a návyků. Mezi vzdělávací metody patří výuka, školení, diskuse, cílený výzkum a praktické vyučování v nemocnici. Vzdělávání probíhá pod vedením jak pedagogů a odborníků $\mathrm{z}$ praxe, ale studenti se mohou a v současné době také vzdělávat více formou samostudia. Nedílnou součástí je také otázka kompetencí a povinností navazujícími na školou nabyté vědomosti, programy celoživotního vzdělávání LLP (Lifelong Learning Programme) a systém ECTS - Evropský kreditní systém pro vysokoškolské vzdělávání, který byl navržen tak, aby pomáhal studentům studovat $\mathrm{v}$ různých zemích, jelikož si mohou nechat uznat svou akademickou kvalifikaci a dobu studia absolvovanou v zahraničí a hledá možnosti propojení jak studijní, tak pracovní spolupráce např́klad v programu Erasmus+.

Analyzovali jsme možnosti výuky a specifika pro obor RAD v prezenční i distanční výuce. Byl kladen důraz na specifika a možnosti pregraduální a postgraduální výuky RAD. V současné době neexistuje žádný volně dostupný vzdělávací text, který by byl adekvátní pro studenty programu Radiologická asistence a pro související obory.

Dnešní učební prostředí je dynamičtější než kdy dříve. Přizpůsobení se a informování o nejnovějších metodách výuky se stalo úkolem pro všechny školy. Př́strojová technika $\mathrm{v}$ radiodiagnostice, nukleární medicíně i radioterapii se bude i nadále vyvíjet, stejně jako studenti a metody výuky. 


\title{
Súčasné trendy $v$ radiačnej ochrane intervenčných rádiológov
}

\author{
Darina Budošová $^{1}$, Martina Horváthová ${ }^{2}$, Zuzana Bárdyová ${ }^{1}$ \\ 1 Trnavská univerzita v Trnave \\ 2 Trnavská univerzita FZaSP \\ darina.budosova@tvu.sk
}

V poslednej dekáde sa počet realizovaných intervenčných výkonov významne zvýšil vdaka širokej škále minimálne invazívnych postupov, ktoré postupne nahrádzajú konvenčné chirurgické procedúry. Napriek mnohým výhodám týchto postupov, je nevyhnutné upriamit pozornost na možné zdravotné riziká vyplývajúce z expozície zdravotníckeho personálu ionizujúcim žiarením. Predchádzajúce štúdie preukázali, že bez adekvátnej radiačnej ochrany môžu intervenční rádiológovia a kardiológovia presiahnut limitné dávky určené pre pracovníkov.

Významným spôsobom ako znížit expozíciu intervenčného rádiológa je využivanie osobných ochranných pracovných prostriedkov (OOPP). Bežne sa využívajú zástery, ochranný golier a okuliare s ekvivalentom olova. Avšak, používanie niektorých OOPP je spojené s diskomfortom pri práci, a to najmä z dôvodu ich tažkej hmotnosti. Za účelom zvýšenia komfortu intervenčného rádiológa boli navrhnuté mnohé ochranné materiály a systémy, ako je bezolovnatá zástera, mobilná ochranná kabína alebo závesný ochranný systém.
Pri výbere bezolovnatých záster je dôležité zvolit správny materiál, ktorý bude poskytovat dostatočne účinnú ochranu. Mobilná ochranná kabína (Cathpax ${ }^{\circledR}$, Lemer Pax, Carquefou, France) poskytuje minimálne rovnakú úroveň radiačnej ochrany ako zástera s ekvivalentom olova a zároveň kryje takmer celé telo intervenčného rádiológa. Zaujímavé výsledky z hladiska radiačnej ochrany poskytuje závesný ochranný systém (ZeroGravity, TIDI Products, MI, USA), ktorý poskytuje vyššiu ochranu pred ionizujúcim žiarením a zároveň odbúrava zátaž na pohybovo-opornú sústavu. Tento systém poskytuje ochranu celej oblasti hlavy pri všetkých pracovných polohách bez obmedzenia viditelnosti alebo pohybu pri práci.

$\mathrm{V}$ príspevku sa budeme zaoberat porovnávaním štandardných a inovatívnych OOPP a zhodnotením ich výhod a nevýhod. Zároveň zosumarizujeme prvotné výsledky našej štúdie zaoberajúcej sa hodnotením efektivity záchytu ionizujúceho žiarenia prostredníctvom štandardných OOPP v porovnaní so závesným ochranným systémom ZeroGravity. 


\title{
Etické aspekty radiologické ochrany ve vnímání radiologických asistentů
}

\author{
Friedo Zölzer ${ }^{1}$, Zuzana Freitinger Skalická ${ }^{2}$, Zuzana Lotterová ${ }^{2}$ \\ ${ }^{1}$ Jihočeská univerzita v Českých Budějovicích \\ ${ }^{2}$ Zdravotně sociální fakulta Jihočeské university \\ zoelzer@zsf.jcu.cz
}

\begin{abstract}
Až donedávna se v rámci radiologické ochrany etika výslovně neřešila. Teprve v roce 2018 vydala Mezinárodní komise pro radiologickou ochranu první publikaci na toto téma s názvem "Etické základy systému radiologické ochrany". Nyní připravuje novou publikaci, která se bude konkrétněji zabývat etickými aspekty radiologické ochrany v lékařské diagnostice a terapii.
\end{abstract}

Cílem zde prezentované studie bylo posoudit, jak vnímají etiku radiologičtí asistenti v České republice. Byly provedeny polo-strukturované rozhovory a dotazníkové šetření mezi přibližně 100 radiologickými asistenty, z nichž zhruba polovina pracuje na radiodiagnostice a další část v nukleární medicíně a radioterapii.

Respondenti až na výjimky potvrdili, že toto téma považují za důležité pro svou profesi, a přibližně dvě třetiny $\mathrm{z}$ nich se při své práci setkali s nějakým etickým dilematem. Téměř všichni si byli vědomi existence etického kodexu pro radiologické asistenty a téměř dvě třetiny z nich měly během své odborné př́pravy alespoň nějakou výuku etiky. Nicméně polovina respondentů se domnívala, že by mohlo existovat více podpory pro ty, kteří se setkají s etickými problémy ve své profesi. Jako témata, kterým je třeba věnovat pozornost, jmenovali respondenti např́klad důstojnost pacienta (nedostatek respektu $\mathrm{k}$ intimitě), transparentnost v komunikaci (nedostatek upř́mnosti $\mathrm{v}$ případech nevyléčitelných onemocnění) a empatii (nedostatek pochopení pro potřeby pacienta).

Naše zjištění jsou alespoň částečně srovnatelná s výsledky průzkumu, který v roce 2013 zveřejnila Americká asociace lékařů (AAPM). Zde téměř dvě třetiny respondentů uvedly, že během svého vzdělávání v oboru lékařské fyziky nedostaly žádné informace týkající se etiky. Přibližně jedna třetina uvedla, že byla svědkem chování, které bylo $\mathrm{v}$ rozporu $\mathrm{s}$ př́nosem pro pacienta nebo bylo neslučitelné se zachováním intimity. Rozdíly mezi našimi výsledky a výsledky amerického průzkumu lze podle našeho názoru interpretovat jako důkaz toho, že čeští radiologičtí asistenti si díky svému vzdělání lépe uvědomují etické problémy, když se s nimi setkají.

$\mathrm{V}$ jiném průzkumu mezi členy AAPM v roce 2015 téměř polovina respondentů uvedla, že se s etickým dilematem v praxi nikdy nesetkala. Dále tito respondenti uvedli, že pokud by taková situace nastala, řídili by se spíše 
svým vnitřním "morálním kompasem" než etickým kodexem nebo obecnými etickými zásadami, zatímco mezi čes- kými radiologickými asistenty je takový intuitivní přistup mnohem méně obvyklý. 


\title{
Gamaspektrometrické měření obsahu radionuklidů po imitaci výbuchu špinavé bomby
}

\author{
Hana Sýbková, Michaela Kozlovská, Petr Otáhal \\ SÚJCHBO, v.v.i. \\ sybkova@sujchbo.cz
}

Jedna z částí při řešení projektu MVČR VH20182021036 - "Moderní metody detekce a identifikace nebezpečných CBRN látek a materiálů, metody snížení jejich nebezpečnosti a dekontaminace; moderní prostředky ochrany osob" se zabývala gamaspektrometrickým měřením kontaminovaných filtrů při realizaci experimentu imitujícího zamoření intravilánu obce při užití špinavé bomby s obsahem radioaktivní látky, konkrétně ${ }^{99 \mathrm{~m}} \mathrm{Tc}$.

Na polygonu, představujícím model intravilánu obce, byly před výbuchem rozmístěny vzorky filtračního materiálu pro vzduchotechniku třídy F9 o rozměrech $20 \times 25 \mathrm{~cm}$ a $30 \times 40 \mathrm{~cm}$, které byly po explozi nádoby s radionuklidem složeny předem stanoveným postupem a vloženy do připravených lékárenských kelímků o objemu $90 \mathrm{ml}$ a do Marinelliho nádob o objemu $600 \mathrm{ml}$. Spektra takto připravených vzorků byla měřena přenosným spektrometrem záření gama s dozimetrickou funkcí GT-40 (detektor NaITl $3 \times 3$ palce) a laboratorními HPGe spektrometry.
Naměřené hodnoty aktivity radionuklidu ${ }^{99 \mathrm{~m}} \mathrm{Tc} \mathrm{v}$ jednotlivých vzorcích filtračního materiálu byly přepočteny na referenční čas a různé způsoby měření filtračního materiálu z jednoho místa byly porovnány mezi sebou. $\mathrm{Na}$ základě předem změřených poloh jednotlivých vzorků filtračního materiálu byla stanovena mapa radioaktivní kontaminace polygonu.

$\mathrm{K}$ odhadu vlivu nehomogenního pokrytí jednotlivých vzorků radionuklidem ${ }^{99 \mathrm{~m}}$ Tc byla část tohoto radionuklidu naředěna a nakapána na kontrolní vzorky filtračního materiálu (o obou velikostech) třemi způsoby: rovnoměrně po celé ploše, pouze ve středu vzorku a pouze na jeho okraji. Na menší referenční vzorek byla nakapána aktivita cca 6,0 kBq k referenčnímu času, na vzorku bylo 120 bodů. Na větší referenční vzorek byla nakapána aktivita cca 13,6 kBq k referenčnímu času, na vzorku bylo 273 bodů. Tyto kontrolní vzorky byly standardně vyhodnoceny a k referenčnímu času byla určena odchylka aktivity nerovnoměrně nakapaných vzorků. 


\title{
Stínící vlastnosti kompozitního nanovlákenného materiálu, vyrobeného metodou elektrostatického zvlákňování
}

\author{
Michaela Kozlovská ${ }^{1}$, Eva Kuželová Koštáková ${ }^{2}$, Jan Grégr $^{2}$, Petr Otáhal ${ }^{1}$ \\ ${ }^{1}$ SÚJCHBO v.v.i. \\ 2 Technická univerzita Liberec \\ kozlovska@sujchbo.cz
}

V rámci projektu Inteligentní textilie proti CBRN látkám - č. VI20172020059, byl metodou elektrostatického zvlákňování vyvinut kompozitní nanovlákenný materiál, zeslabující rentgenové záření a záření gama. Kompozitní materiál tvořila polymerová matrice z polyvinylbutyralu, obsahující nanočástice těžkých kovů (až do hmotnostní koncentrace $95 \%$ ). Obsah nanočástic v materiálu byl testován termogravimetrickou analýzou (TGA), homogenita nanočástic $\mathrm{v}$ nanovláknech a v celé vrstvě byla zkoumána pomocí SEM/EDS. Byla rovněž testována cytotoxicita vzorků.

Zeslabení rtg. a gama záření ve vzorcích bylo stanoveno pomocí měření spekter rtg. a gama záření různých radionuklidů spektrometrem X-123 CdTe v geometrii úzkého svazku. Mezi sebou byly porovnávány čisté plochy píků ve spektrech, kdy mezi zdrojem a detektorem nebyl vložen žádný materiál, a kdy byl mezi zdroj a detektor vložen testovaný vzorek. Kromě zeslabení rtg. a gama záření o energiích hlavních energetických linek použitých radionuklidů byly pro jednotlivé vzorky na těchto energiích stanoveny hmotnostní koeficienty zeslabení a ekvivalenty olova.

Pro určité energie byly pomocí software FLUKA provedeny Monte-Carlo simulace spekter daných radionuklidů jak bez vzorků mezi zdrojem a detektorem, tak i s jednotlivými testovanými vzorky mezi nimi. Obdobným způsobem, jako z naměřených spekter, bylo pro dané energie stanoveno zeslabení rtg. a gama záření v jednotlivých vzorcích a výsledky byly porovnány. 


\title{
Monitoring trícia vo vodách za rok 2020
}

\author{
Natália Žabková, Anna Ondrušková \\ Úrad verejného zdravotníctva SR \\ natalia.gasparova@uvzsr.sk
}

Monitorovanie rádioaktívnej kontaminácie jednotlivých zložiek životného prostredia sa vykonáva $\mathrm{v}$ súlade so zákonom č. $87 / 2018$ Z. z. o radiačnej ochrane o zmene a doplnení niektorých zákonov a s vyhláškou Ministerstva zdravotníctva Slovenskej republiky č. 96/2018 Z. z., ktorou sa ustanovujú podrobnosti o činnosti radiačnej monitorovacej siete. Monitoring rádioaktivity životného prostredia prebiehal v roku 2020 v súlade s monitorovacím plánom vypracovaným podla požiadaviek vyššie uvedenej vyhlášky a v súlade s úlohami vyplývajúcimi z článkov 35 a 36 Zmluvy Euratom podla požiadaviek Európskej komisie.

V rámci hodnotenia vplyvu ožiarenia na obyvatel'stvo je trícium dôležitým rádiologickým ukazovatelom analyzovaným vo vzorkách pitných vôd a povrchových vôd, vo vzorkách odpadových vôd z jadrových zariadení a vo vzorkách atmosférických zrážok. Indikačná hodnota tohto rádiologického ukazovatela je upravená vo vyhláške Ministerstva zdravotníctva Slovenskej republiky č. 100/2018 Z. z., ktorou sa ustanovujú podrobnosti na obmedzovanie ožiarenia z pitnej vody, z prírodnej minerálnej vody a z pramenitej vody. Laboratóriá monitorovania, laboratórnych analýz a havarijnej pripravenosti Odboru radiačnej ochrany Úradu verejného zdravot- níctva Slovenskej republiky postupujú podla určeného monitorovacieho plánu, pričom objemová aktivita trícia je stanovovaná vo vzorkách pitných vôd a povrchových vôd, vzorkách odpadových vôd z jadrových zariadení a vo vzorkách atmosférických zrážok v mesačných a kvartálnych intervaloch.

Cielom tohto odborného príspevku je zosumarizovat výsledky stanovení objemovej aktivity rádiologického ukazovatela $\mathrm{H}-3$, ktoré prebiehali v roku 2020 vo vzorkách z vybraných lokalít, ako v okolí AE Jaslovské Bohunice a AE Mochovce, tak aj na miestach, kde sa odoberajú referenčné vzorky. Odber vzoriek pitných vôd prebiehal v súlade s STN ISO 5667-5, odber vzoriek povrchových vôd s STN EN ISO 5667-6 a odber vzoriek odpadových vôd s STN ISO 5667-10. Stanovenie objemovej aktivity trícia vo vzorkách prebiehalo metódou kvapalinovej scintilačnej spektrometrie podla STN EN ISO 9698, bol použitý kvapalinový scintilačný spektrometer Quantulus GCT 6220. Výsledky analýz z roku 2020, ale aj z predchádzajúcich rokov, sú verejne dostupné na webovej stránke Úradu verejného zdravotníctva Slovenskej republiky vo forme výročných správ a sú zasielané každoročne Európskej komisii v rámci plnenia článkov 35 a 36 zmluvy Euratom. 


\title{
Testování vybraných metod pro dekontaminaci velkoplošných povrchů zamořených radioaktivními látkami
}

\author{
Josef Holeček, Hana Sýbková, Petr Otáhal, Eva Zemanová \\ SÚJCHBO v.v. i. Kamenná \\ holecek@sujchbo.cz
}

V rámci řešení výzkumného úkolu „Moderní metody detekce a identifikace nebezpečných CBRN látek a materiálů, metody snížení jejich nebezpečnosti a dekontaminace, moderní prostředky ochrany osob" byl hledán optimální způsob dekontaminace velkoplošných povrchů městské infrastruktury. Byla sestavena metodika, která umožňuje srovnání různých dekontaminačních postupů na základě hodnoty dekontaminační účinnosti, množství dekontaminačního činidla a množství vzniklého kontaminovaného odpadu. V rámci testování byl pro dekontaminaci pěnou použit $3 \%$ roztok RDS-2000 a pro dekontaminaci kapalnou směsí $3 \%$ roztok ODS-5. Obě dekontaminační činidla byla z kontaminovaného povrchu odstraněna pomocí vysavače. Pro kontaminaci neradioaktivním kontaminantem byl použit fotoluminiscenční pig- ment GLOWSTAR, pro kontaminaci radioaktivním kontaminantem Tc-99m. Kontaminovanými povrchy byly stavební materiály používané ke stavbě budov městské infrastruktury. Z testů realizovaných v rámci řešení úkolu vyplynulo, že spotřeba dekontaminačního činidla ve formě pěny je nižší než při použití činidla v kapalné formě. Také se potvrdil vznik menšího množství vzniklého kontaminovaného odpadu při dekontaminaci povrchu pomocí pěny. Výsledky odhalily skutečnost, že nezanedbatelná část dekontaminačního činidla zůstává na povrchu i po skončení dekontaminace. Při použití dekontaminačního činidla ve formě pěny může množství činidla zbylého na povrchu dosáhnout až 90 \% naneseného množství. U kapalného činidla se tento podíl pohybuje v rozmezí 40-50\%. 


\title{
Stanovení poměru fixované a nefixované kontaminace radioaktivní látkou
}

\author{
Eva Zemanová, Eliska Fialova, Josef Holeček, Petr Otáhal \\ SÚJCHBO, v.v.i. \\ zemanova@sujchbo.cz
}

\begin{abstract}
V rámci řešení projektu VH20182021036 je důležité z hlediska potenciální dru„Moderní metody detekce a identifikace hotné kontaminace zasahujícího personebezpečných CBRN látek a materiáli̊, nálu či techniky v průběhu likvidace metody snížení jejich nebezpečnosti následků mimořádné události spojené a dekontaminace; moderní prostředky s uvolněním radioaktivní látky do okolochrany osob“, byl realizován experi- ního prostředí. Během experimentu mentální výbuch „špinavé“" bomby na byla zkoumána účinnost stěru hladkých polygonu simulujícím náměstí. Cílem ploch na několika terčích na podlaze experimentu bylo mimo jiné ověření a stěnách polygonu. Měřením plošné funkčnosti metodiky týkající se sta- aktivity před a po provedení stěrů na novení poměru fixované a nefixované jednotlivých místech byla z množství kontaminace radioaktivní látkou. Sta- odstraněné aktivity kontaminantu pronovení podílu nefixované kontaminace centuálně vyjádřena účinnost stěru.
\end{abstract}




\title{
Vel'kost' dávky ionizujúceho žiarenia obdržanej pri lekárskom ožiarení a implementácia tejto informácie do diagnostického popisu vyšetrenia
}

\author{
Zuzana Bárdyová ${ }^{1}$, Martina Horváthová ${ }^{2}$, Vladimír Neuschl ${ }^{3}$, Igor Gomola ${ }^{4}$ \\ 1 Trnavská univerzita v Trnave \\ 2 Trnavská univerzita FZaSP \\ 3 MRI s. r. o. \\ $4 \mathrm{SZU}$
}

zuzanabardyova@gmail.com

Lekárske zobrazovanie patrí medzi klúčové súčasti klinickej praxe vdaka využitiu v diagnostike, ale aj pri následnom sledovaní účinnosti liečby mnohých ochorení. Technologické pokroky a zároveň stále pribúdajúce klinické indikácie $\mathrm{v}$ posledných rokoch vyústili do rutinného používania rádiologických zobrazovacích metód. Tento nárast vyšetrení zákonite sprevádza aj zvýšená radiačná zátaž, ktorá však v porovnaní s ich prínosom tahá za pomyselný „kratší koniec". Avšak, nevyhnutnou súčastou je zabezpečit snímanie s čo najnižšou radiačnou zátažou, akú je možné dosiahnut (princíp ALARA).

$\mathrm{S}$ cielom zabezpečit radiačnú ochranu pacienta a zvýšit povedomie o velkosti dávky ionizujúceho žiarenia (IŽ) obdržaného počas rádiologických vyšetrení, bolo v rámci Smernice rady 2013/59/EURATOM stanovené, aby rádiológ do diagnostického popisu nálezu zahrnul údaj o dávke IŽ z lekárskeho ožiarenia. Toto usmernenie bolo implementované do slovenskej legislatívy - Vestníka Ministerstva zdravotníctva Slovenskej republiky (MZ SR), Koncepcia zdravotnej starostlivosti v odbore rádiológia (Vestník MZ
SR, 1.jún 2020, čiastka 7-8, roč. 68), v ktorom sa uvádza: „Pri používaní röntgenových diagnostických prístrojov musia byt súčastou popisu vyšetrenia aj údaje o dávke pacienta z lekárskeho ožiarenia alebo údaje umožňujúce posúdit velkost ožiarenia pacienta, distribúciu dávok u pacienta v závislosti od vekovej kategórie a pohlavia. V odôvodnených prípadoch je potrebné uviest aj zhodnotenie rizika $\mathrm{z}$ ožiarenia a potenciálnu zdravotnú ujmu."

Napriek tomu, že spomínaný Vestník nadobudol účinnost od 1. júna 2020, údaj o dávke IŽ v popise vyšetrení rádiologických pracovísk do dnešného dňa absentuje. Pracovisko MRI s.r. o. v Trnave predstavuje prvé rádiologické pracovisko v SR, ktoré aplikovalo do diagnostického popisu obrazovej dokumentácie z výpočtovej tomografie, skiagrafie a mamografie údaj o dávke IŽ. Kedže žiadna direktíva nekonkretizuje, ktoré veličiny majú byt súčastou popisu nálezu, pracovisko túto informáciu udáva vo forme veličín, v ktorých sú vyjadrené diagnostické referenčné úrovne.

Cielom príspevku je upozornit na jeden z bodov radiačnej ochrany nachá- 
dzajúci sa v európskej, ako aj slovenskej formácie o dávke pacienta z lekárskeho legislatíve, na ktorý sa nekladie dosta- ožiarenia do diagnostického popisu vytočný dôraz. Zároveň je cielom zdôraz- ̌̌etrenia všetkých rádiologických praconit nevyhnutnost implementovania in- vísk v SR. 


\title{
Precise experimental determination of attenuation coefficient and its simulation
}

\author{
Jiří Burian ${ }^{1}$, Štefan Čerba $^{2}$, Marko Erich ${ }^{3}$, Vendula Filová ${ }^{1}$, \\ Marko Gloginjić ${ }^{3}$, Karel Katovský ${ }^{1}$, Jakub Luley ${ }^{2}$, Željko Mravik ${ }^{3}$, \\ Vladimír Nečas ${ }^{2}$, Srdjan Petrović ${ }^{3}$, Ondřej Št'astný ${ }^{1}$, Branislav Vrban ${ }^{2}$ \\ 1 Vysoké učení technické v Brně \\ 2 Slovenská technická univerzita v Bratislave \\ 3 VINČA Institute of Nuclear Sciences, Belgrade \\ katovsky@vut.cz
}

With regard to progress achieved in computation methods of ionizing radiation transport in various materials, there is increased need for validation of such computer codes with experiments. Therefore, special measurement equipment has been built at Brno University of Technology. It serves for experimental determination of attenuation coefficients of various shielding materials. Special focus is put on inhomogeneous materials, new composites, and non-standard shielding bricks which are usually used for various inside shielding reinforcement. Various measurements methods are tested, different detectors (gas filled, semi-conductor, scintillation, etc.) are used. Dependence on measurement geometry is also tested. Basic build-up factor measurements have also been done and its investigation will continue. Experimental results are then compared with values obtained by Monte Carlo methods based codes such as MCNP and PHITS. Results are then compared with literature and possibility of the methodology further utilization is discussed in conclusions. 


\title{
About translational radiooncology - past, present, future
}

\author{
Antje Dietrich \\ OncoRay - National Center for Radiation Research in Oncology \\ antje.dietrich@uniklinikum-dresden.de
}

In the lecture, I will give an overview about translational research in radiation oncology and how models and research questions changed in time. I will show clinical examples leading from large trials, testing one new drug, to so called basket trials in the area of precision medicine. In addition, I will discuss the development of preclinical radiooncological research touching classical models and assays and introduce some of the state-of-the-art research which can be realized using advanced in virtro models, precise image-guided small animal irradiation workflows, heterogeneous tumor cohorts as well as preclincial radiomics-approaches. 


\title{
Dávka je len jedna dimenzia biologického účinku
}

\author{
Dušan Šalát ${ }^{1}$, Denisa Nikodemová \\ ${ }^{1}$ Ústav radiačnej ochrany, s.r.o. \\ salat@uro.sk
}

Biologické účinky ionizujúceho žiarenia sú často diskutované najmä v oblasti nízkych dávok. Radiačná hormézia, hypersenzitivita, prahová alebo lineárna teória popisujú závislost medzi účinkom a dávkou, ale zvyčajne predstavujú iba jeden pohlad - jednu dimenziu na interakciu ionizujúceho žiarenia s hmotou. Vzhladom k tomu, že výskum v oblasti nízkych dávok neustále pokračuje, cielom tohto príspevku je poukázat aj na dalšie dimenzie pri hodnotení rizík biologického poškodenia organizmu, najmä v oblasti lekárskeho ožiarenia. 


\title{
Biologická účinnost a dozimetrie alfa zářičů v buněčných experimentech
}

\author{
Lukáš Ondrák ${ }^{1}$, Pavel Kundrát ${ }^{2}$, Marek Sommer ${ }^{2}$, Martin VIk $^{1}$, \\ Václav Štěpán ${ }^{2,1}$, Marie Davídková ${ }^{2}$ \\ ${ }^{1}$ FJFI ČVUT v Praze \\ 2 Oddělení dozimetrie záření, Ústav jaderné fyziky AV ČR, v. v. i. \\ ondraklukas@gmail.com
}

Radiofarmaka obsahující ve své molekule beta zářiče jako např. Sm-153 nebo Lu-177 mají široké využití v nukleární medicíně pro terapeutické účely jak kurativní, tak paliativní. Za velice slibnou metodu v oblasti terapie v nukleární medicíně se poslední roky ukazuje cílená alfa částicová terapie, v níż jsou pomocí selektivně vychytávaného nosiče do nádoru dopraveny radionuklidy emitující alfa částice o vysoké biologické účinnosti a krátkém doletu. Výhodné jsou zejména tzv. in vivo alfa generátory, které podléhají sérii alfa rozpadů, např. Ra-223 nebo Ac-225 produkující čtyři alfa částice.

Pro efektivní aplikaci této stále nové metody je nezbytná znalost biologické účinnosti alfa částic a mechanismů, které $\mathrm{k}$ jejich efektu přssívají. $\mathrm{V}$ rámci testování vlivu vybraných alfa a beta radionuklidů na buněčné úrovni jsme studovali inaktivaci buněk DU145 (lidský adenokarcinom) v závislosti na aktivitě beta záŕiče Lu-177 nebo alfa zářiče Ra-223, které byly buňky vystaveny. $\mathrm{V}$ obou případech s rostoucí aktivitou klesal podíl přežívajících buněk ve shodě s klasickým lineárněkvadratickým popisem. V souladu s očekáváním bylo Ra-223 při stejné ak- tivitě mnohem účinnější než Lu-177. Abychom měřená data mohli prezentovat standardním způsobem pomocí křivek přežití v závislosti na dávce, odhadli jsme deponovanou dávku za předpokladu, že veškerá rozpadová energie bude předána do vzorku a rozdělena v něm homogenně. Oproti známým pozorováním s externími zdroji záření však z tohoto odhadu nevyšla biologická účinnost alfa částic několikrát vyšší, ale jen srovnatelná jako u beta částic.

Zmíněný odhad deponované dávky se proto jeví jako hrubě zjednodušený. K ověření předpokladů o rovnoměrné distribuci dávky jsme pomocí dvojice detektorů Timepix provedli měření jednotlivých částic emitovaných vzorkem média s těmito radionuklidy, a to paralelně ve spodní a $\mathrm{v}$ horní části vzorku. Zatímco pro Lu-177 byly výsledky v obou částech srovnatelné, pro Ra-223 jsme detekovali výrazně vyšší počet alfa částic $\mathrm{v}$ horní části vzorku. To naznačuje, že k primárnímu rozpadu Ra-223 a emisi první alfa částice sice dochází homogenně v celém vzorku, ale produkt tohoto rozpadu, Rn-219, stoupá vzhůru díky své plynné formě, takže $\mathrm{k}$ jeho rozpadu a rozpadu 
jeho produktů dochází převážně v horní části buněčného média.

Výsledky ukazují, že dozimetrie alfa zářičů $\mathrm{v}$ buněčných experimentech je komplikovaná a diskuze implikací pro in vivo situaci bude vyžadovat podrobnější měření a doplnění MC simulacemi. 


\title{
Od makroskopického transportu záření ke struktuře stopy na mikroskopické úrovni
}

\author{
Pavel Kundrát ${ }^{1}$, Giorgio Baiocco ${ }^{2}$, Andrea Ottolenghi ${ }^{2}$, Werner Friedland ${ }^{3}$ \\ ${ }^{1}$ Ú.JF AV ČR, v. v. i. \\ ${ }^{2}$ University of Pavia, Italy \\ ${ }^{3}$ Helmholtz Zentrum München, Germany \\ kundrat@ujf.cas.cz
}

Biologické účinky ionizujícího záření jsou dány prostorovým rozdělením jednotlivých depozic energie, zejména jejich shlukováním na nanometrových a mikrometrových škálách. Tuto oblast velmi dobře zachycují simulace struktury stopy záření, a to jak pro fotony a elektrony, tak pro těžké nabité částice. Ve spojení s modely DNA a chromatinu tyto simulace umožňují odhadovat poškození DNA, tvorbu chromozomálních aberací a inaktivaci buněk různými druhy záření, které se používají v radioterapii nádorových onemocnění, v průmyslu nebo mají význam napřr. z hlediska radiační ochrany kosmonautů.

Pro praktické aplikace $\mathrm{v}$ těchto oborech jsou neméně cenné modely transportu záření na makroskopických škálách. Ty umožňují např. výpočet dávkového rozložení v těle pacienta nebo účinnosti stínění na palubě kosmické lodi.

Přímé propojení těchto komplementárních přístupů, tedy mikroskopického a makroskopického popisu interakcí záření s hmotou, do jednotného simulačního nástroje naráží kromě jiných ob- tíží i na extrémní výpočetní náročnost. Slibný alternativní přístup spočívá v zachycení výsledků simulací struktury stopy záření a poškození DNA a chromatinu pomocí analytických funkcí, které pak mohou být jednoduše implementovány do modelů makroskopického transportu záření. Daný postup kombinuje výhody makroskopického a mikroskopického přístupu. Rozšiřuje oblast, kde mohou být využity modely struktury stopy záření, do makroskopické oblasti. Současně doplňuje výsledky makroskopických transportních modelů o popis výsledků fyzikálních, chemických a biologických procesů, které se odehrávají na mikroskopických škálách.

$\mathrm{V}$ příspěvku shrneme simulace poškození DNA a chromatinu pomocí biofyzikálního programu PARTRAC pro různé typy záření. Představíme, jak lze výsledky simulací zachytit pomocí analytických funkcí reprezentujících poškození v závislosti na druhu částic a jejich lineárním přenosu energie (LET) nebo jejich energii. Popíšeme, jak lze tyto výsledky spojit s makroskopickými modely. 


\title{
Rakovina plic, radon a kouření
}

\author{
Ladislav Tomášek \\ SÚRO, v.v.i. \\ ladislav.tomasek@suro.cz
}

Cílem prezentace je hodnocení rizika rakoviny plic ve vztahu $\mathrm{k}$ expozici radonu a kouření. Je založena na studií př́padů a kontrol vnořené do kohortové studie téměř 20000 horníků uranových dolů. Profesionální expozice d.p. radonu v této vnořené studii byly retrospektivně doplněny o kuřácká data získaná od jednotlivých osob (nejčastěji z lékařské dokumentace) nebo jejich př́ibuzných. Studie zahrnuje téměř
1200 př́padi̊ rakoviny plic, z nich 120 nekuřáků. Kombinovaný účinek radonu a kouření je analyzován pomocí tzv. geometrických smíšených modelů, přičemž aditivní a multiplikativní modely jsou jejich speciální případy. Hodnocení závisí podstatně na charakteristikách, které popisují kuřáckou expozici. Výsledný model je bližší aditivnímu působení radonu a kouření. 


\title{
Odškodňování nemocí z povolání u horníků UD v ČR
}

\author{
Ladislav Tomášek, Tomáš Müller \\ SÚRO, v.v.i.
}

tomas.muller@suro.cz

\begin{abstract}
Česká republika má dlouhou tradici koviny kůže a leukémie. Prezentace potěžby uranové rudy z hlubinných dolů. dává přehled vývoje kritérií posuzování To je spojeno se zvýšeným rizikem ra- nemocí z povolání u horníků UD za pokoviny plic. Již zákon RČS č. 99/1932 uvádí rakovinu plic způsobenou radioaktivními paprsky a emanací. Od roku 1962 byl posuzováním a evidencí nemocí z povolání pověřen ZÚNZ UP Př́ibram. Kritéria posuzování prošla svým vývojem $\mathrm{v}$ závislosti na poznatcích z epidemiologických studií. Podstatnou část posuzovaných případů tvoří rakovina plic, následují nemelanomové rasledních 60 let. Tato kritéria zahrnují dobu práce $\mathrm{v}$ podzemí i koncentrace radonu. Od roku 1989 je posuzování založeno na podílu př́činné souvislosti, který vychází z regresních modelů relativního rizika. Odhady koeficientů relativního rizika $\mathrm{v}$ těchto modelech jsou pak dále zpřesňovány v závislosti na době sledování horníků, a tím i jejich věku.
\end{abstract}




\title{
Vliv kultivačních podmínek na radiosensitivitu meduloblastomových buněk
}

\author{
Jana Klementová ${ }^{1}$, Markéta Farníková ${ }^{1}$, Irina Danilova ${ }^{1}$, Šárka Jarošová ${ }^{2}$, \\ Martina Zíková ${ }^{2}$, Marie Davídková ${ }^{1}$ \\ ${ }^{1}$ ODZ, Ústav jaderné fyziky AV ČR \\ 2 Ústav molekulární genetiky AV ČR \\ jana.klementova@img.cas.cz
}

Rakovina mozku a nervového systému představuje u dětí po leukémii druhé nejčastější nádorové onemocnění. Asi 8-10 \% dětských nádorů mozku tvoří meduloblastomy. Pro laboratorní výzkum meduloblastomů je možné využít různé buněčné linie patřící do odlišných molekulárních subtypů meduloblastomů. Některé z těchto buněčných linií je možné kultivovat in vitro $\mathrm{v}$ adherentních podmínkách jako jednovrstevnou buněčnou kulturu. Zároveň je ale také možné tyto buňky pěstovat v suspenzních podmínkách, kde tvoří sféry.

Meduloblastomové buňky DAOY jsme kultivovali ve standartních adherentních podmínkách a $\mathrm{v}$ bezsérovém médiu s růstovými faktory jako sféry. Buňky jsme ozařovali pomocí kobaltového ozařovače a sledovali jsme jejich přežití a viabilitu. Metodou kvantita- tivní PCR a imunofluorescence jsme dále také sledovali změny v expresi neurálních genů a genů známých jako markery nádorových kmenových buněk.

Buňky kultivované jako sféry tvoří výrazně heterogenní strukturu, která obsahuje jak zvýšené množství nádorových kmenových buněk, tak i velké množství buněk v různých stupních diferenciace. Tyto buňky odpovídají na ozáření odlišně $\mathrm{v}$ porovnání s homogennější populací buněk kultivovaných adherentně.

$\mathrm{V}$ současné době se při většině in vitro pokusů používá jednovrstevná buněčná kultura kultivovaná ve standartních adherentních podmínkách. Heterogenní buněčná populace sfér ale představuje model bližší situaci in vivo. Proto jsme se v naší práci zaměřili na porovnání radiosensitivity buněk kultivovaných v různých podmínkách. 


\title{
Dynamics of p53 in response to DNA damage caused by radiation
}

\author{
Irina Danilova ${ }^{1}$, Martina Zíková$^{2}$, Jana Klementová ${ }^{1,2}$, Marie Davídková ${ }^{1}$ \\ ${ }^{1}$ ÚJF AV ČR, v. v.i. \\ 2 ÚMG AV ČR, v. v. i. \\ danilova@ujf.cas.cz
}

The TP53 gene is one of the major tumor suppressor genes. The p53 protein plays a role as a transcription factor that controls the expression of about 60 genes. The p53 protein functions as a DNA damage sensor in the cell and regulates a number of key cellular processes, including cell cycle arrest, DNA repair, apoptosis, senescence, and cell survival.

In our experiments, we focused on the effect of low doses irradiation on the oscillatory dynamics of the p53 protein. We used the breast cancer cell line MCF7 and irradiated the cells with a cobalt source. Protein levels were detected by Western blot analysis and expression levels of selected p53responsive genes were determined by quantitative real-time PCR.

We detected the oscillatory dynamics of p53 protein after irradiation at both high and low doses. Our results were further confirmed by measuring changes in the expression of p53regulated genes.

Since more than half of human cancers have mutations in the TP53 gene and a significant proportion of cancer patients receive radiation as a critical part of their treatment, the goal of our project is to investigate the dynamics of the p53 protein in tumor cells. 


\title{
Záhada zvýšení buněčné odezvy indukované protony v př́tomnosti boru
}

\author{
Irina Danilova, Marie Davídková, Zuzana Jamborová, Anna Jelinek \\ Michaelidesova, Kateřina Pachnerová Brabcová, Pavel Kundrát, \\ Václav Štěpán, Oldřich Zahradníček \\ ODZ, ÚJF AV ČR, v.v.i. \\ davidkova@ujf.cas.cz
}

Protonová terapie vyniká při léčbě nádorových onemocnění výhodnou dávkovou distribucí, která umožňuje ušetřit ozáření zdravé tkáně. Experimenty s buněčnými liniemi prokázaly, že při ozáření protonovými svazky dochází v př́itomnosti boru ke zvýšení biologického účinku, a to až o $75 \%$. Možný diskutovaný mechanismus spočívá ve fúzní reakci protonů $\mathrm{s}{ }^{11} \mathrm{~B}$, ke které dochází zejména při nízkých energiích protonů v Braggově píku, nebo sekundárních neutronů $\mathrm{s}{ }^{10} \mathrm{~B}$. V obou případech jsou produkovány alfa částice krátkého dosahu a vysoké ionizační hustoty. Nepatrné zvýšení deponované dávky však nevysvětluje pozorovaný biologický účinek. K objasnění mechanismu tohoto efektu jsme $\mathrm{v}$ rámci projektu podporo- vaného Grantovou agenturou České republiky zahájili cílené experimenty, ve kterých chceme studovat tři hypotézy: biologický účinek lze vysvětlit dávkou navýšenou fyzikálními procesy, které nebyly zahrnuty do předchozích odhadů; bor působí jako radiosenzitizátor a zvyšuje radiační odezvu na buněčné úrovni; buňky obsahující bor iniciují mezibuněčnou komunikaci, která zesiluje efekt protonového záření na úrovni celé buněčné populace. Objasnění mechanismu umožní odhadnout výhody př́padné aplikace boru $\mathrm{v}$ radioterapii.

$\mathrm{V}$ tomto př́spěvku nastíníme strategii jednotlivých experimentů testujících navržené hypotézy a představíme první slibné výsledky. 


\title{
Zvýšená biologická účinnost protonového ozařování buněk v př́tomnosti boru pravděpodobně není způsobena sekundárními neutrony
}

\author{
Anna Jelinek Michaelidesova ${ }^{1,2}$, Oldřich Zahradníček ${ }^{2}$, Kateřina Pachnerová \\ Brabcová $^{2}$, Irina Danilova ${ }^{2}$, Jana Vachelová ${ }^{2}$, Jan Vilimovský ${ }^{3}$, \\ Pavel Kundrát ${ }^{2}$, Mirek David ${ }^{4}$, Vladimír Vondráček ${ }^{3}$, Marie Davídková ${ }^{2}$
${ }^{1}$ ÚJF AV ČR, v.v. i. ${ }^{2}$ FJFI ČVUT v Praze
${ }^{3}$ Proton Therapy Center Czech
${ }^{4}$ Thomayerova nemocnice \\ michaelidesova@ujf.cas.cz
}

V borové neutronové záchytové terapii se používají borové sloučeniny, které se selektivně hromadí v nádorech. Pro tuto metodu se používají sloučeniny, které jsou oproti př́rodnímu boru (20\% B-10 a $80 \%$ B-11) vysoce obohacené o izotop B-10. Záchyt neutronů na boru B-10 produkuje jednu alfa částici a Li-7, obojí s vysokou ionizační hustotou a krátkým dosahem, což vede k vysoké biologické účinnosti v úzce vymezené oblasti.

Podobná reakce protonů $\mathrm{s}$ př́rodně dominantním izotopem boru B-11 vede ke vzniku dokonce tř́i alfa částic. Její účinný průřez výrazně roste $\mathrm{s}$ klesající energií protonů a je nejvyšší v oblasti Braggova píku. Tato reakce by mohla nalézt uplatnění jako tzv. proton-borová fúzní terapie (PBFT). Alfa částice produkované $\mathrm{v}$ oblasti Braggova píku by násobily výhody ostrého dávkového rozložení v protonové radioterapii. Tato hustě ionizující komponenta by př́padně mohla pomoci překonat radiorezistenci hypoxických nádorů. V roce 2018 byly publikovány radiobiologické experimenty, které potvrdily vliv př́rodního boru na buněčné přežití v rošîreném Braggově píku protonového svazku. Zjištěné nižší přežití se připsalo reakci B-11 s nízkoenergetickými protony. Toto tvrzení rozpoutalo vášnivé diskuze mezi protonovými radiobiology. Známé účinné průřezy reakce protonů s B-11 a Monte Carlo simulace totiž ukazují, že tato reakce vede jen $\mathrm{k}$ nepatrnému navýšení dávky a neměla by mít tedy vliv na přežití buněk.

V naší práci jsme v Protonovém centru Praha za použití glioblastomové buněčné linie U87 ověřili, že kombinace přírodního boru s nízkoenergetickým protonovým svazkem snižuje buněčné přežití. Jelikož by toto nemělo být způsobeno reakcí protonů a B-11, tak další hypotézou je, že to může být reakcí neutronů vzniklých při protonové terapii s B-10, který je přítomný $\mathrm{v}$ přírodním boru. K testování hypotézy, jsme ozářili buňky na LINACu v Thomayerově nemocnici v Praze fotonovými svazky se dvěma energiemi $6 \mathrm{MV}$ a $18 \mathrm{MV}$, a to za použití jak přírodního boru, tak obohaceného B-10. Zatímco $6 \mathrm{MV}$ svazky nemají dostatečnou energii pro tvorbu neutronů, $18 \mathrm{MV}$ fotony produ- 
kují neutrony v podobném množství a se srovnatelnými energetickými spektry jako použité protonové svazky. Na fotonových svazcích se žádný vliv boru na přežití buněk neprojevil. Provedené experimenty tak ukazují, že zvýšená biologická účinnost protonového ozařování buněk v přítomnosti boru pravděpodobně není způsobena sekundárními neutrony. 


\title{
Radiačné poškodenie plazmidovej DNA s bórovým nosičom
}

\author{
Zuzana Jamborová ${ }^{1}$, Marie Davídková ${ }^{1}$, Anna Jelinek Michaelidesova ${ }^{1}$, \\ Egor Ukraintsev ${ }^{2}$, Irina Danilova ${ }^{1}$, Oldřich Zahradníček ${ }^{1}$, \\ Kateřina Pachnerová Brabcová ${ }^{1}$ \\ ${ }^{1}$ ODZ, ÚJF AV ČR, v. v.i. \\ ${ }^{2}$ Fyzikalní Ústav AV ČR \\ jamborova@ujf.cas.cz
}

Pri hladaní efektívnejších metód radiačnej liečby rakoviny experimenty na úrovni buniek naznačujú až o $75 \%$ zvýšenú biologickú efektivitu protónového žiarenia v prítomnosti bóru. Je však otázne, aký mechanizmus za týmto stojí. Táto štúdia si kladie za ciel zistit, či na bunkovej kultúre pozorované efekty budú viditelné aj na úrovni DNA. $\mathrm{K}$ tomuto sme použili vzorky DNA plazmidu pBR322, ktoré sme ožarovali zdrojom ${ }^{60} \mathrm{Co}$ a protónovým žiarením v prítomnosti rastúcich koncentrácií $\mathrm{BSH}\left(\mathrm{Na}_{2} \mathrm{~B}_{12} \mathrm{H}_{11} \mathrm{SH}\right)$ obsahujúcej prírodné zloženie izotopov bóru a
BSH obohatenú o ${ }^{10} \mathrm{~B}$. Tento nosič je používaný $\mathrm{v}$ experimentoch bunkovej radiobiológie a hlavne pri záchytovej neutrónovej terapii mozgových nádorov.

Radiačné poškodenie DNA bolo analyzované pomocou agarózovej elektroforézy. Opakované experimenty ukázali, že výtažky poškodení klesajú v prítomnosti BSH úmerne s jeho koncentráciou z čoho vyvodzujeme, že BSH pôsobí na úrovni DNA ako vychytávač volných radikálov, t. j. ochraňuje DNA pred poškodením. 


\title{
Biological effects of low-dose radiation
}

\author{
Anna Lierová ${ }^{1}$, Jan Novotný ${ }^{2}$, Marcela Milanová ${ }^{3}$, Jaroslav Storm ${ }^{3}$, \\ Lenka Andrejsová ${ }^{4}$, Zuzana Šinkorová ${ }^{4}$ \\ ${ }^{1}$ Katedra radiobiologie, Fakulta vojenského zdravotníctva, UO \\ ${ }^{2}$ Katedra klinických oborů, FZS, UPCE \\ ${ }^{3}$ Katedra radiobiologie, FVZ, UO \\ ${ }^{4}$ Fakulta vojenského zdravotnictví, Univerzita obrany, Hradec Králové \\ anna.lierova@unob.cz
}

In the modern world, ionizing radiation (IR) plays an important role. Dramatic rise in diagnostic procedures, radioisotope's exposures scans and intervention procedures has raised a concern about long-term biological consequences from exposure to low doses of IR. Besides its unambiguous relevance to medical benefits, knowledge of the long-term health outcomes of exposure to low dose ionizing radiation is also essential for various industrial applications. There has been a growing number of scientific evidence regarding the biological effects of low-dose radiation (LDR) in recent years. The term low dose means a cumulative dose up to $100 \mathrm{mSv}$.

Contrary to high dose rate irradiation, biological effects after LDR exposure are linked bipolar effect phenomena; positive as adaptive responses, radiation hormesis or hypersensitivity and negative as bystander effect, radio- resistance or genomic instability. Due to these phenomena, biological effect of LDR is complex, but still incompletely understood.

The aim of our work is to provide relevant information about effects associated with biological consequences. We reviewed recent current available studies of LDR-induced effects in humans. This study is based on literature reviews method. Majority of summarized studied confirmed the mutual correlation between the biological risk and LDR (induction of $\gamma$-H2AX, formation of micronucleus or chromosomal aberrations...). Although, LDR issue still remains relatively new topic that need to be more thoroughly explored and thus a total view of the biological effects and relevant mechanism. It is quite likely, according to the information gathered that further research of LDR may lead to opportunity of individual diagnostics into the future. 


\title{
Simulace poškození DNA při ozáření deuterony, heliem-3 a dalšími izotopy
}

\author{
Pavel Kundrát ${ }^{1}$, Werner Friedland ${ }^{2}$, Giorgio Baiocco ${ }^{3}$, Andrea Ottolenghi ${ }^{3}$ \\ ${ }^{1}$ ÚJF AV ČR, v. v.i. \\ ${ }^{2}$ Helmholtz Zentrum München, Germany \\ ${ }^{3}$ University of Pavia, Italy \\ kundrat@ujf.cas.cz
}

Simulace založené na podrobném zachycení struktury stopy záření úspěšně popisují závislost biologických účinků na typu ionizujícího záření. Byla provedena řada simulací pro fotony, elektrony, protony i těžši ionty s energiemi pokrývajícími rozsah používaný v radioterapii nádorových onemocnění, $\mathrm{v}$ technické praxi nebo zastoupené $\mathrm{v}$ kosmickém záření. Otázka rozdílné účinnosti různých izotopů jednoho prvku však simulacemi studována nebyla. Přitom např́́klad při radioterapii uhlíkovými ionty vznikají např̀. sekundární pro- tony, deuterony, helium-4 i helium-3, ale i uhlík-11.

Pro simulace biologických účinků různých izotopů pomocí biofyzikálního nástroje PARTRAC jsme předpokládali, že ostatní izotopy daného prvku s elektronovým obalem molekuly vody interagují stejně jako standardně uvažovaný izotop, který by se pohyboval stejnou rychlostí. V prríspěvku budou prezentovány výsledky simulací poškození DNA a chromatinu při ozařování buněk deuterony, heliem-3 a dalšími izotopy. 


\title{
Proteins of double-strand break and western blot analysis
}

\author{
Jiří Toufar ${ }^{1}$, Lucie Dobešová ${ }^{1}$, Eva Pagáčová ${ }^{1}$, Olga Kopečná ${ }^{1}$, Iva Falková ${ }^{1}$, \\ Alena Bačíková ${ }^{1}$, Michael Hausmann ${ }^{2}$, Martin Falk ${ }^{1}$ \\ ${ }^{1}$ Biofyzikální ústav AV ČR, v. v.i. \\ ${ }^{2}$ Kirchhoff-Institute for Physics, University of Heidelberg \\ toufar.jiri@gmail.com
}

Ionising irradiation (IR), such as $\gamma$ - or $\mathrm{X}$-rays from medical treatments, high energy charged particles from cosmic radiation, is one of most serious factors to endanger human health. IR can produce a variety of DNA damage structures including double-strand breaks (DSB), which are considered to be a most deleterious DNA lesions and could potentially be a major threat to genome stability. Therefore, DSBs need to be addressed and countered by DNA repair pathways and its proteins. This has generated an immense amount of interest in acquiring more knowledge of this topic and created other experimental designs. What we are following is measuring of levels of various proteins in response to $\gamma$ - irradiation of different cell lines - U87 (human primary glioblastoma cell line), SkBr3 (human breast cancer cell line) and NHDF (Normal Human Dermal Fibroblasts). Using this, we try to find out the selected pathway for DNA repair and monitor this at different times after IR. Western blotting analysis is there used for determining levels of $\gamma \mathrm{H} 2 \mathrm{AX}, \mathrm{MRE} 11, \mathrm{RAD} 51$, PARP1, $53 \mathrm{BP} 1$ and other proteins of interest occurring in separate DNA damage response mechanisms. First results show promise and indicate us some variances in protein levels in different times after IR and more importantly some similar patterns. In future plans, we will try to use different types of nanoparticles and observe how protein levels are affected after $\gamma$ or possibly $\mathrm{X}$-ray irradiation and moreover, if the chosen pathway of DNA repair mechanism is modified or changed.

Supported by the project: DFG 20$04109 \mathrm{~J}$ 


\title{
The relationship between PD-L1/PD-1/MHC-1/Her2/and other immune or oncogenic receptors
}

\author{
Elham Parsimehr ${ }^{1}$, Lucie Dobešová ${ }^{1}$, Jiří Toufar ${ }^{1}$, Eva Pagáčová ${ }^{1}$, \\ Olga Kopečná ${ }^{1}$, Iva Falková ${ }^{1}$, Alena Bačíková ${ }^{1}$, Michael Hausmann ${ }^{2}$, \\ Martin Falk ${ }^{1}$ \\ ${ }^{1}$ Biofyzikální ústav AV ČR, v. v.i. \\ ${ }^{2}$ Kirchhoff-Institute for Physics, University of Heidelberg \\ elhamparsimehr@gmail.com
}

Cancer cells create distinct pathways to escape immune monitoring and are steadily expanding. Cytotoxic innate and adaptive immune cells can regulate the development of carcinoma by quite different receptors. At present, several costimulating molecules have discoverd, such as t-cell Immunoglobulin, the programmed death 1 (PD-1)/programmed ligand 1 (PD-L1) axis and lymphocyticactivating gene-3 (LAG3), HER2 (human epidermal growth factor receptor 2) which act alone or in concert to keep $\mathrm{T}$ cells in check and enable tumor cells to escape, with the different effect depending on the kind and stage of cancer.

These molecules' interactions can be correlated or anti-correlated, resulting in immunosuppressive and immunostimulatory responses. PD-L1 expression is now regarded as one of the most significant indicators for predicting ICI impact. As evidence of these findings, Cytoplasmic DNA potently activates the cGAS/STING pathway and PD-L1 expression (currently considered as a „negative“ response), while DNA damage also leads to enhanced HLA-neoantigen presentation (positive response). In a very simplified scenario, the PD-L1 receptor on the tumor (and some immune) cell surface interacts with its PD-1 ligand on $\mathrm{T}$ lymphocytes (or other immune cells), inhibit their proliferation, and suppresses the antitumor immune response. KPNB1 is a nuclear receptor responsible for the nuclear transport of HER2. Interestingly, anticorrelation between PD-L1 and Her2 points to a possible competition of these important oncoproteins for KPNB1 transporter.

According to most studies, high expression of Oncogene (HER2) is frequently related to deficient expression of antigen processing machine components of MHC Class I via RAS/MAPK signaling in different cancer types.

$\mathrm{T}$ cells co-expressing LAG3 and PD-1 are significantly exhausted compared with T cells that express LAG3 or PD-1 alone.Also, LAG-3 and PDL1 synergized to regulate T-cell activity, producing immunological resistance. Targeted drugs (like IMP321) that inhibit LAG3/MHCII interaction increase tumor-related CD8 production and cytokines. Thus, many cancer ther-

Biologické účinky a zdravotní hlediska 
apies can target the balance of these responses.

The determination of oncogenic status (Epidermal growth factor receptor
(EGFR), programmed death-ligand 1 (PD-L1), HER2, etc.) is required for combination treatments that of cancers. 


\title{
Radiosensitizers in radiotherapy - gold nanoparticles
}

\author{
Lucie Dobešová $^{1}$, Jiř́ Toufar ${ }^{1}$, Eva Pagáčová ${ }^{1}$, Olga Kopečná ${ }^{1}$, Iva Falková ${ }^{1}$, \\ Alena Bačíková1, Michael Hausmann ${ }^{2}$, Martin Falk ${ }^{1}$ \\ ${ }^{1}$ Biofyzikální ústav AV ČR, v. v.i. \\ ${ }^{2}$ Kirchhoff-Institute for Physics, University of Heidelberg \\ dobesovalucy@gmail.com
}

The application of radiosensitizers in the treatment and diagnosis of cancer is one of the most studied scientific topics. There are several types of radiosensitizers - nitro-acids, cell inhibitors, nanoparticles etc. The properties of gold nanoparticles predetermine them for wide use not only in radiotherapy. Treatment of cancer with ionizing radiation is one of the most widely used methods. Therefore, there is a great effort in scientific circles to improve this method towards the least possible damage to healthy tissue. For these reasons, I'm focusing on the study of the effects of gold nanoparticles Au-c, $\mathrm{Au}-10$, Aurion 10nm and Aurion 25nm on cancer (Sk-Br-3) and healthy / nor- mal (NHDF) cells in the process of radiosensitization. Various methods are used to study the cellular response to incubation with nanoparticles (MTT tetrazolium assays, cell viability assays and activation of apoptosis by flow cytometry etc.). We found that $\mathrm{Au}-\mathrm{c}$ nanoparticles show a cytotoxic effect in the Sk-Br-3 cell line, but not in the NHDF line. The selective cytotoxicity of these nanoparticles could be useful in other industries of cancer treatment. No effect was demonstrated for the other types of nanoparticles examined, but could occur with the use of another source of ionizing radiation.

Supported by the project: DFG 20$04109 \mathrm{~J}$ 


\title{
Vývoj nových radioprotektivních látek na bázi malých molekulárních inhibitorů
}

\author{
Alžběta Filipová ${ }^{1}$, Jan Marek ${ }^{2}$, Aleš Tichý ${ }^{1}$, Radim Havelek ${ }^{3}$, \\ Martina Majorošová ${ }^{3}$, Lenka Andrejsová ${ }^{\text {, }}$ Tomáš Kučera ${ }^{1}$, Lukáš Prchal ${ }^{2}$, \\ Lubica Múčková1, Martina Rezáčová ${ }^{3}$, Zuzana Šinkorová ${ }^{1}$, Jaroslav Pejchal ${ }^{1}$, \\ Marcela Milanová1, Jana Čížková ${ }^{1}$ \\ 1 Fakulta vojenského zdravotnictví, Univerzita obrany, Hradec Králové \\ 2 Centrum biomedicínského výzkumu, Fakultní nemocnice Hradec Králové \\ 3 Lékařská fakulta v Hradci Králové, Univerzita Karlova \\ alzbeta.filipova@unob.cz, jana.cizkova@unob.cz
}

Technická aplikace ionizujícího záření (IZ) má dramatický dopad na zdravotnictví, cestování vesmírem, výzkum a energetický průmysl. Katastrofické efekty IZ byly bohužel využity také prostřednictvím vývoje jaderných zbraní; kromě toho došlo v jaderných energetických reaktorech $\mathrm{k}$ několika nehodám, které měly za následek ekologické katastrofy a ztráty na životech. Potenciální riziko radiační expozice proto zdůrazňuje potřebu nových radioprotektivních látek. Za tímto účelem byly syntetizovány nové sloučeniny na bázi derivátů 1(2-hydroxyethyl)piperazinu, které byly charakterizovány pomocí nukleární magnetické rezonance a hmotnostní spektrometrie s vysokým rozlišením, následované cytotoxickým a radioprotektivním hodnocením in vitro a in vivo. $\mathrm{V}$ naší již publikované práci jsme otestovali, že látka 3e vykazovala nejvýznamnější radioprotektivní účinek u ozářených myší C57Bl/6J a naopak látka $3 \mathrm{j}$ významně snížila dobu jejich přežití, proto jsme se rozhodli zaměřit na testování radioprotekce/radiosenzitivity látek 3e a $3 \mathrm{j}$ u myšího kmene Balb/c, protože myši z tohoto kmene mají odlišný genetický profil než myší kmen C57Bl/6J. 


\title{
3D buněčný model pro radiobiologii: in ovo kultivace nádorových buněk
}

\author{
Oldřich Zahradníček ${ }^{1}$, Mária Hovořáková ${ }^{2}$, Marie Davídková $^{1}$ \\ ${ }^{1}$ ÚJF AV ČR, v. v.i. \\ 2 1. Lékařská fakulta UK v Praze \\ zahradnicek@ujf.cas.cz
}

Buněčné linie derivované z lidských tumorů jsou nejčastěji používaným modelem v radiobiologickém výzkumu. Drtivá většina experimentů probíhá na 2D buněčných kulturách pěstovaných v supraoptimálních podmínkách kultivačních médiích. Takovéto kultury jsou svou ekologií odlišné od tumoru v těle pacienta. Nicméně experimenty na nich jsou snadno opakovatelné, statisticky vyhodnotitelné a cenově přijatelné. Vzhledem k výše zmíněným negativům je vhodné verifikovat pozorované skutečnosti na 2D buněčných kulturách experimenty na 3D kulturách propojených s modelovým organismem obratlovce. Jako cenově a legislativně dostupným modelem se jeví model in ovo pěstování buněk v kolagenových houbičkách na chorioalantoidní membráně, zárodečném obalu kuřecích zárodků (Kavaliauskaite et al., 2017). Zde se propojují kultivované buňky v kolagenové houbičce s tkání chorioalantoidní membrány včetně cév. V našich experimentech jsme použili dvě lidské buněčné linie derivované ze zhoubných nádorů mozku, a to U251 a U87 glioblastomy. Jako 3D lešení pro buňky jsme pou- žili zmíněnou kolagenovou houbičku a testovali jsme vhodnost kolagenu z krysích ocásků a gelu na bázi celulózy, jakožto složek napodobující funkci mezibuněčné hmoty. Tyto analogy mezibuněčné hmoty jsou důležité pro uchycení buněk v houbičce a pro mezibuněčnou komunikaci a transport látek. Před aplikací buněk do kolagenové houbičky jsme tedy buňky smíchali bud's kolagenem z krysích ocásků, nebo s rostlinným gelem na bázi celulózy v různých koncentracích. Tuto buněčnou suspenzi jsme následně aplikovali do kolagenové houbičky, která se následně umístila na chorioalantoidní membránu kư̌ecích zárodků v 7. dni inkubace. Buňky se nechaly ve vejcích růst po následujících 5 dnů a pak byly kolagenové houbičky odebrány, zafixovány a histologicky zpracovány. Pilotní pokusy ukázaly, že tkáň zárodečných obalů obrostla kolagenové houbičky a $\mathrm{z}$ buněk obou linií se vytvořily mikro nádory. $\mathrm{V}$ testovaných koncentracích se jeví kolagen z krysích ocásků jako vhodnější substituent mezibuněčné hmoty než rostlinný analog. 


\section{Rejstřík}

Milanová Marcela, 151

Ambrožová Iva, 27, 36, 44, 63, 64, 93, 96,100

Ambrožová I., 28

Andrássy Erik, 41

Andrejsová Lenka, 30, 32, 33, 145, 151

Assmann Vratislavská Hana, 43

Avtandilashvili Maia, 22

Bačíková Alena, 147, 148, 150

Baiocco Giorgio, 136, 146

Balogová Zdenka, 37, 109

Bankov N., 92

Bárdyová Zuzana, 110, 112, 121, 129

Bártová Iva, 37

Bednár Dávid, 75

Benghin V.V., 92

Bobík Pavol, 29, 96

Böhm Karol, 106

Böhm Radoslav, 79, 80, 86, 94

Bonková Ivana, 59

Brandýsová Alžbeta, 84

Brož Pavel, 62

Brunclík Tomášs, 63

Budošová Darina, 121

Bulko Martin, 79, 80, 84, 94

Burian Jiří, 131

Burianová Jelena, 67

Cimmino Anna, 44

Csicsay Kristian, 89

Czakoj Tomáš, 60

Čarný Peter, 70

Čechák Tomáš, 37

Čemusová Zina, 20, 21

Čerba Štefan, 24, 53, 54, 131

Čipáková Andrea, 82
Čížková Jana, 30, 32, 33, 151

Dachev Tsvetan, 92

Danilova Irina, 139-142, 144

Daniška Dušan, 74

Daňová Kristína, 103

David Mirek, 142

Davídková Marie, 100, 134, 139-142, 144, 152

Dietrich Antje, 132

Dimitrov P., 92

Dobešová Lucie, 147, 148, 150

Dobynde M., 28

Doubravová Daniela, 47

Dulanská Silvia, 76

Ď́ranová Tatiana, 65

Durdyová Veronika, 82

Ďurecová Alžbeta, 82

Eckertová Terézia, 85, 86, 94

Ekendahl Daniela, 20, 21, 35, 42

Erich Marko, 131

Falk Martin, 147, 148, 150

Falková Iva, 147, 148, 150

Farkas Gabriel, 40

Farníková Markéta, 139

Fedosov F., 92

Fialova Eliska, 66, 128

Fialová Anna, 57

Fialová Eliška, 98

Filipová Alžběta, 30, 32, 33, 151

Filová Vendula, 131

Fojcíková Eva, 70

Fojtík Pavel, 23, 46

Foltínová Lubica, 25, 102

Forgáč Matej, 68 
Freitinger Skalická Zuzana, 122

Freitinger-Skalická Zuzana, 101, 103, 120

Friedland Werner, 136, 146

Fülöp Marko, 25, 102, 117

Galbavý Andrej, 113

Gébeová Klára, 76

Giuffrida Lorenzo, 38

Gloginjić Marko, 131

Golovin D., 92

Gomola Igor, 76, 102, 110, 112, 113, 129

Granja Carlos, 55

Grebennikova N., 92

Grégr Jan, 125

Häder D.P., 92

Hanušová Tereza, 39

Hausmann Michael, 147, 148, 150

Havelek Radim, 151

Havránková Renata, 120

Helebrant Jan, 67

Helej Markus, 94

Hinca Róbert, 40

Holeček Josef, 66, 127, 128

Holý Karol, 79-81, 84-86, 94

Horneck G., 92

Horváthová Martina, 110, 112, 121, 129

Hovořáková Mária, 152

Hudzietzová Jana, 117

Hupka Ivan, 35

Chernykh I., 92

Chroust J., 28

Chum Jaroslav, 63

Chvátil David, 44

Inozemtsev K. O., 28

Istokskaia Valeria, 38

Ivanova O.A., 92
Jamborová Zuzana, 141, 144

Ján Ružička, 25

Jarošová Šárka, 139

Jeličová Marcela, 30

Jelinek Michaelidesova Anna, 100, 141, 142, 144

Jiříková Petra, 101

John David, 88

Johnová Kamila, 97

Jordanova M., 92

Judas Libor, 20, 21

Jurčo Milan, 25

Kafka Vladimír, 61

Kajan Miroslav, 77

Kákona Jakub, 64

Kákona Martin, 27, 36, 64, 93

Kákona M., 28

Kapuciánová Michaela, 20, 21

Kaschner Martin, 61

Katovský Karel, 24, 131

Kavan Štěpán, 120

Kitamura H., 28, 92

Kleinová Kamila, 82

Klementová Jana, 139, 140

Klusoň Jaroslav, 49, 50, 69, 97, 100

Knežević Željka, 99

Kodaira S., 28, 62

Koleva R., 92

Kolros Antonín, 43

Koniarová Irena, 119

Kontul' Ivan, 94

Kopečná Olga, 147, 148, 150

Koštál Michal, 60

Kotková Kristýna, 57

Kovář Ivan, 93

Kozlovec Petr, 57

Kozlovská Michaela, 66, 124, 125

Kozyrev A., 92

Kožešníková Dominika, 98

Krásny Dušan, 73

Krastev K., 92 
Kratochvíl Vojtěch, 103

Krbal Michal, 26

Krist Pavel, 62

Krivošík Matej, 59

Krofta Tomáš, 57

Křováková Kateřina, 71

Kubancak J., 92

Kubančák Ján, 93, 96

Kubínová Marie, 42

Kuča Petr, 20, 67

Kučera Tomáš, 151

Kufnerová Jitka, 58

Kundrát Pavel, 57, 134, 136, 141, 142, 146

Kureková Patrícia, 81

Kurková Dana, 21

Kušnyerová Alexandra, 82

Kuželová Koštáková Eva, 125

Langer Ronald, 63, 96

Lebert M., 92

Libus Petr, 115

Lierová Anna, 30, 32, 145

Limburská Kateřina, 52

Linhart Vladimír, 39

Linhartová Hana, 115

Lipták Ludovít, 70

Lištjak Martin, 75

Litvak M., 92

Lotterová Zuzana, 122

Luley Jakub, 24, 53, 54, 131

Lužová Martina, 62, 64, 93

Mackovjak Šimon, 96

Majorošová Martina, 151

Malahov A., 92

Malchev St., 92

Marčišovská Mária, 62, 70

Marčišovský Michal, 61, 62

Marek Jan, 151

Margarone Daniele, 38

Marko Erich, 24
Marko František, 89

Marko Gloginjić, 24

Martinčík Jiř́i, 37

Masarik Jozef, 84, 85, 94

Mašek Petr, 63

Matěj Zdeněk, 60

Mátel Lubomír, 76

Matviichuk Yu., 92

Mikeš Jan, 26

Mikula Peter, 40

Milanová Marcela, 32, 145

Mitrofanov I., 92

Mojzeš Andrej, 41, 89

Mokrousov M., 92

Motta Silvia, 44

Mravik Željko, 131

Múčková Lubica, 151

Müller Tomáš, 138

Müllerová Monika, 78, 81, 84, 85, 94

Nečas Vladimír, 24, 53, 54, 68, 74, 75,131

Nemček Peter, 117

Němeček Ladislav, 48

Neuschl Vladimír, 129

Nikiforov S., 92

Nikodemova Denisa, 105, 108

Nikodemová Denisa, 106, 113, 133

Nikolaev I., 92

Nogová Ema, 41

Novák Evžen, 60

Novotný Jan, 145

Olsovcova Veronika, 38, 44

Olšanský Václav, 44

Ondráček Jakub, 66

Ondrák Lukáš, 134

Ondrušková Anna, 126

Otáhal Petr, 48, 66, 98, 124, 125, 127, 128

Ottolenghi Andrea, 136, 146

Pagáčová Eva, 147, 148, 150 
Pachnerová Brabcová Kateřina, 56$58,88,141,142,144$

Pajdhauser Ivo, 25

Parsimehr Elham, 148

Pavel Kundrát, 88

Pejchal Jaroslav, 151

Petriska Martin, 40

Petrov V., 92

Petrović Srdjan, 131

Ploc Ondřej, 26, 27, 36, 62-64, 93, 96

Ploc O., 28, 92

Povišer Martin, 64

Prchal Lukáš, 151

Procházka Jan, 71

Ragan Pavol, 25, 102

Rapant Tibor, 72

Reimitz Dan, 35

Reitz G., 92

Rovenská Vendula, 23

Rubovič Peter, 46

Rulík Petr, 71

Řezáčová Martina, 151

Sabol Jozef, 117

Sanin A., 92

Sejkora Jiř́i, 98

Semkova J., 92

Shurshakov V. A., 28

Shurshakov V.A., 92

Schuster M.T., 92

Sihver L., 28

Siková Lenka, 37

Slavíček Tomáš, 46

Slučiak Jarmila, 59

Smetanová Iveta, 81, 89

Sochor Vladimír, 45, 116

Sommer Marek, 27, 62, 64, 93, 134

Spurny F., 92

Srdjan Perović, 24

Staněk Pavel, 61
Storm Jaroslav, 145

Stránský Vojtěch, 38, 44

Strhársky Igor, 96

Strhárský Igor, 63

Stríbrnský Branislav, 40

Strnad David, 87

Stýblová Eva, 101

Suchánek Petr, 62

Suchý Václav, 57

Súkupová Lucie, 109

Světlík Ivo, 56-58, 88

Sýbková Hana, 66, 124, 127

Sýkora Ivan, 85, 94

Šabata Ladislav, 103

Šagátová Andrea, 25, 102

Šalát Dušan, 105, 106, 108, 133

Šefl Martin, 22

Šimek Pavel, 57

Šimon Jan, 60

Šímová Iva, 71

Šináglová Růžena, 90

Šinkorová Zuzana, 30, 32, 33, 145, 151

Škrkal Jan, 71, 77

Šlegl Jakub, 63

Šmoldasová Jana, 45, 47, 116

Šolc Jaroslav, 44, 45, 47, 116

Štastný Ondřej, 24, 131

Štěpán Václav, 26, 87, 134, 141

Štěpánová Dagmar, 26, 27, 93, 96

Štika Jan, 100

Švecová Dominika, 29

Švihra Peter, 61

Tamášová Jana, 37

Tecl Josef, 56

Thinová Lenka, 49, 87

Tichý Aleš, 151

Tolmachev Sergei Y., 22

Tolochek R. V., 28

Tomášek Ladislav, 137, 138 
Tomov B., 92

Toufar Jiří, 147, 148, 150

Trantina Václav, 98

Trebichalský Vladimír, 82

Tretyakov V., 92

Trojanová Eliška, 47

Trojek Tomáš, 51, 52

Trojková Darina, 51

Truneček Roman, 44

Turek Karel, 93

Uchihori Y., 92

Ukraintsev Egor, 144

Urban Tomáš, 69

Vachelová Jana, 142

Valášek Vojtěch, 57, 58

Válek Jan, 57

Velyhan Andriy, 44

Velychko Olena, 27, 36, 93

Velychko O., 28

Vendula Filova, 24

Versaci Roberto, 38

Vičanová Magdaléna, 82

Viererbl Ladislav, 43

Vilimovský Jan, 142
Vlk Martin, 134

Vondráček Vladimír, 142

Vondrák Andrej, 117

Vostrukhin A., 92

Vošahlík Josef, 48, 66

Vrba Tomáš, 34, 39

Vrba Václav, 62

Vrban Branislav, 24, 53, 54, 68, 74, 131

Vykydal Zdeněk, 20, 21

Wallová Gabriela, 41

Yarmanova E.N., 92

Záhorová Věra, 77

Zahradníček Oldřich, 141, 142, 144, 152

Zankl Marie, 19

Zemanová Eva, 66, 127, 128

Zíková Martina, 139, 140

Zölzer Friedo, 122

Zubáková Anita, 106, 113

Žabková Natália, 126

Željko Mravik, 24

Ženatá Ivana, 90, 98 



\section{$\triangle \frac{\text { Canberra }}{\text { Packard }}$}

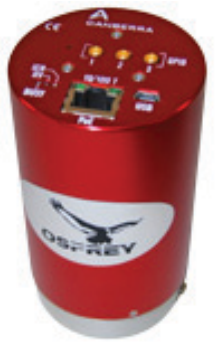

Osprey $^{\mathrm{TM}}-$

Universal Digital MCA Tube Base for Scintillation Spectrometry

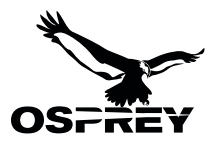

Lynx ${ }^{\circ}$

Digital Signal Analyzer
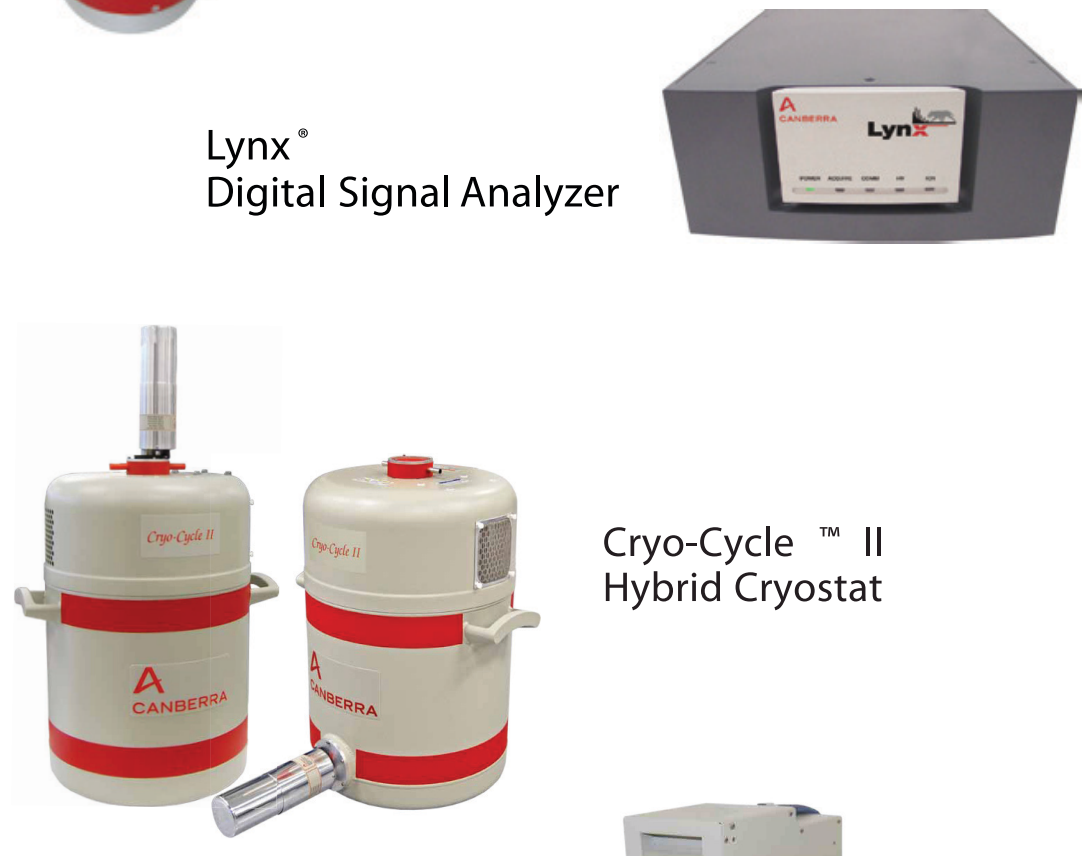

Cryo-Cycle ${ }^{\mathrm{Tm}}$ II Hybrid Cryostat

Cryo-Pulse 5 plus Electrically

Refrigerated Cryostat

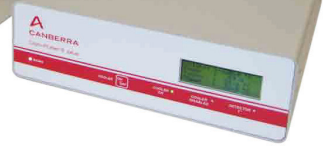




\section{EcoGamma}

\section{Environmental Gamma}

Radiation Monitor

\section{Colibri :}

Hand-Held Health Physics

Communication ALARA* Platform
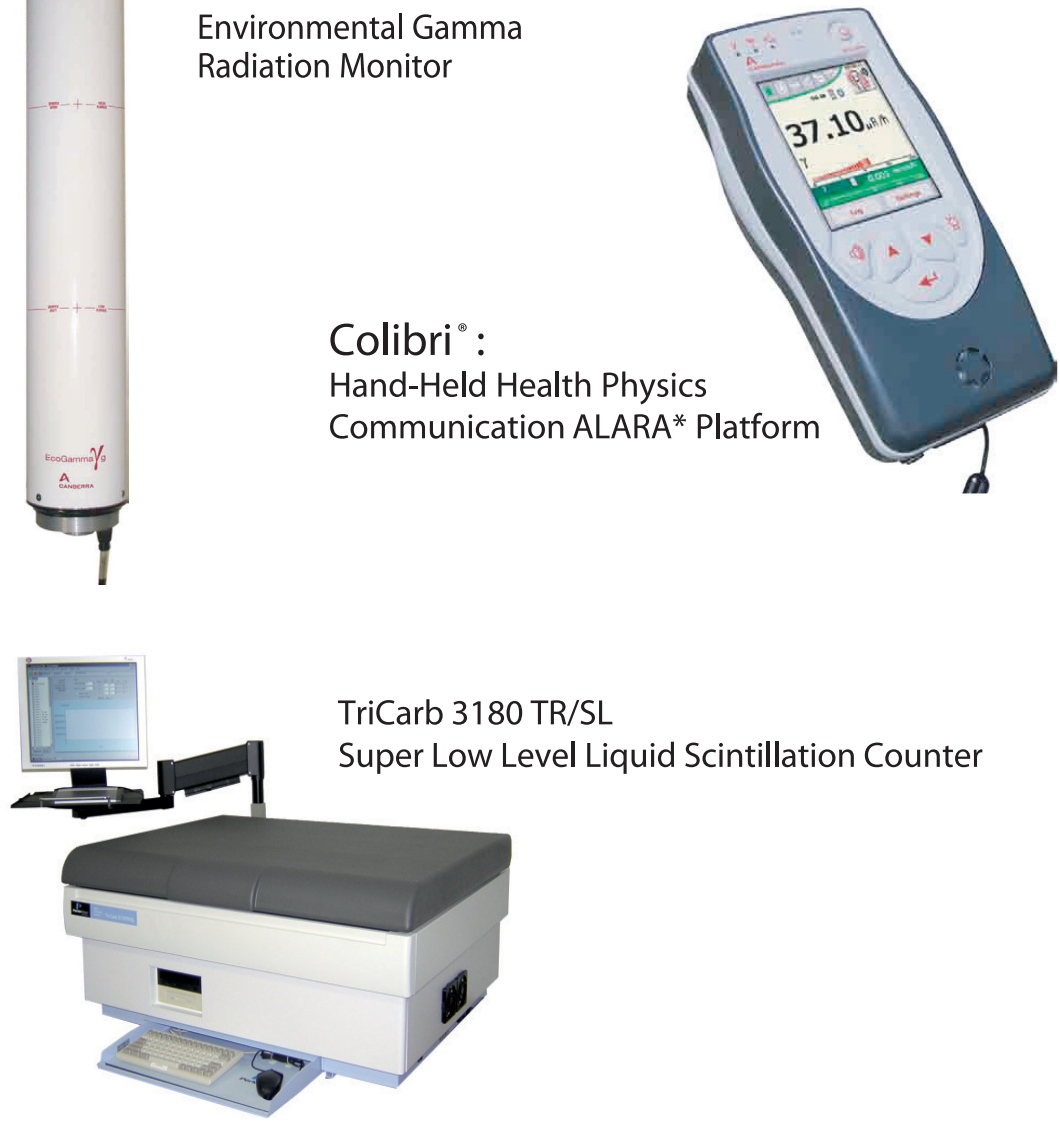

Wizard

Automatic Gamma Counter

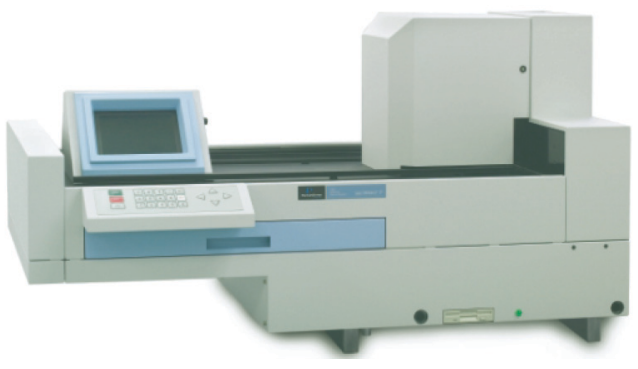

CANBERRA PACKARD

Central Europe $\mathrm{GmbH}$

Wienersiedlung 6 , A-2432 SCHWADORF

Phone: +43(0)2230 3700-0

Fax: $\quad+43(0) 22303700-15$

e-mail: cpce@cpce.net

internet: www.cpce.net
Czech Republic:

CANBERRA PACKARD spol. s r.o.

Sultysova 37, CZ-16900 PRAHA 6

Phone: +420-233090031

Fax: $\quad+420-233090032$

e-mail: cpcz@cpce.net

internet: www.cpce.net 
Tradiční český dodavatel a výrobce specializované měřicí techniky EMPOS, spol. s r.o., K Fialce 1165/5, 15500 Praha, www.empos.cz

\section{Analyzátor a specializované měřicí sestavy pro měření ionizujícího záření}

Srdcem našich měřicích sestav je moderní digitální 4000 kanálový spektrální analyzátor MCA4K, který má Certifikát o schválení typu měřidla. $V$ kombinaci s vhodnou sondou/sondami, geometrií měření a softwarem jsme schopni dodat měřicí systém na míru konečnému uživateli v souladu s konkrétními legislativními požadavky.

\section{Standardně dodávané spektrometrické sestavy}

EMPOS EMS-1 SH/TV (Nízkopozad’ová gama, 6-komponentní analýza)

- měření obsahu prírodních radionuklidů ve stavebních materiálech, stanovení hmotnostní aktivity ${ }^{226} \mathrm{Ra}$, ${ }^{228} \mathrm{Th} /{ }^{232} \mathrm{Th},{ }^{40} \mathrm{~K}$ a indexu hmotnostní aktivity,

- měření radioaktivity tavbových vzorků oceli, stanovení hmotnostní aktivity ${ }^{60} \mathrm{Co}$.

EMPOS EMS-7 (Nízkopozad'ová gama)

- stanovení objemové aktivity radonu ${ }^{222} \mathrm{Rn}$ ve vzorcích vody o objemu $250 \mathrm{ml}$ nebo $500 \mathrm{ml}$ podle požadavků normy ČSN 757624 (čl. 6), resp. STN 757615.

\section{EMPOS EMS 8}

- měření obsahu radonu a rádia ve vodách, měření půdního radonu a radonu v okolním vzduchu.

\section{Nízkopozad'ové alfa-beta automaty EMPOS EMS-3 a EMS-3.2}

- automatizované měření celkové alfa aktivity a celkové beta aktivity radionuklidů ve vzorcích sedimentů, odparků, prášků, stěrů, rostlin nebo v pevných látkách. Umožňují stanovení radioaktivity materiálů a předmětů z životního prostředí, biologických a biochemických vzorků, kontrolu radioaktivní kontaminace potravin, půdy, pitné a odpadní vody (ve formě odparků). V odebraných vzorcích umožňuji stanovit aktivitu prírodního uranu, ${ }^{210} \mathrm{Po},{ }^{226} \mathrm{Ra},{ }^{241} \mathrm{Am}$, resp. ${ }^{40} \mathrm{KCl},{ }^{210} \mathrm{~Pb},{ }^{90} \mathrm{Sr}$, a to $v$ závislosti na volbě měřící metody, použitého etalonu nebo standardu a zvolené radiochemické přípravě vzorku.

\section{Analyzátor MCA4K - $\mathbf{4 0 0 0}$ kanálový amplitudový analyzátor}

- je určen pro fyzikální aplikace a rutinní měření v průmyslu a laboratorních provozech, pracovištích hygieniků a vodohospodárů, kde je vyžadována snadnost obsluhy a přitom možnost nastavovat parametry algoritmu analýzy amplitudy pulsů a dalších parametrů měření. Diagnostika vstupního signálu a i během měření vestavěným digitálním osciloskopem a zpětné měření nastaveného vysokého napětí pro sondu.

Jako doplněk měřicích sestav dodáváme olovem stíněné manipulační pomůcky

(laminární boxy, stíněné trezory, stíněné kazety, aplikační stolky, stínění injekčních stř́ikaček)

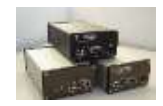

Analyzátory MCA4K

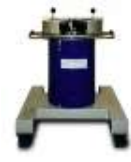

Stíněná studna

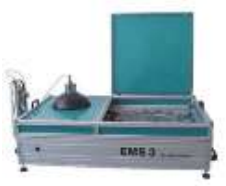

Alfa-beta automat

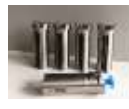

Kryty injekčních stříkaček

Jsme také autorizovaným lokálním distributorem zahraničních firem se zaměřením na radiofrekvenční měření, měření elmag. pole, výkonové zdroje, útlumové členy, příslušenství a dalších. 


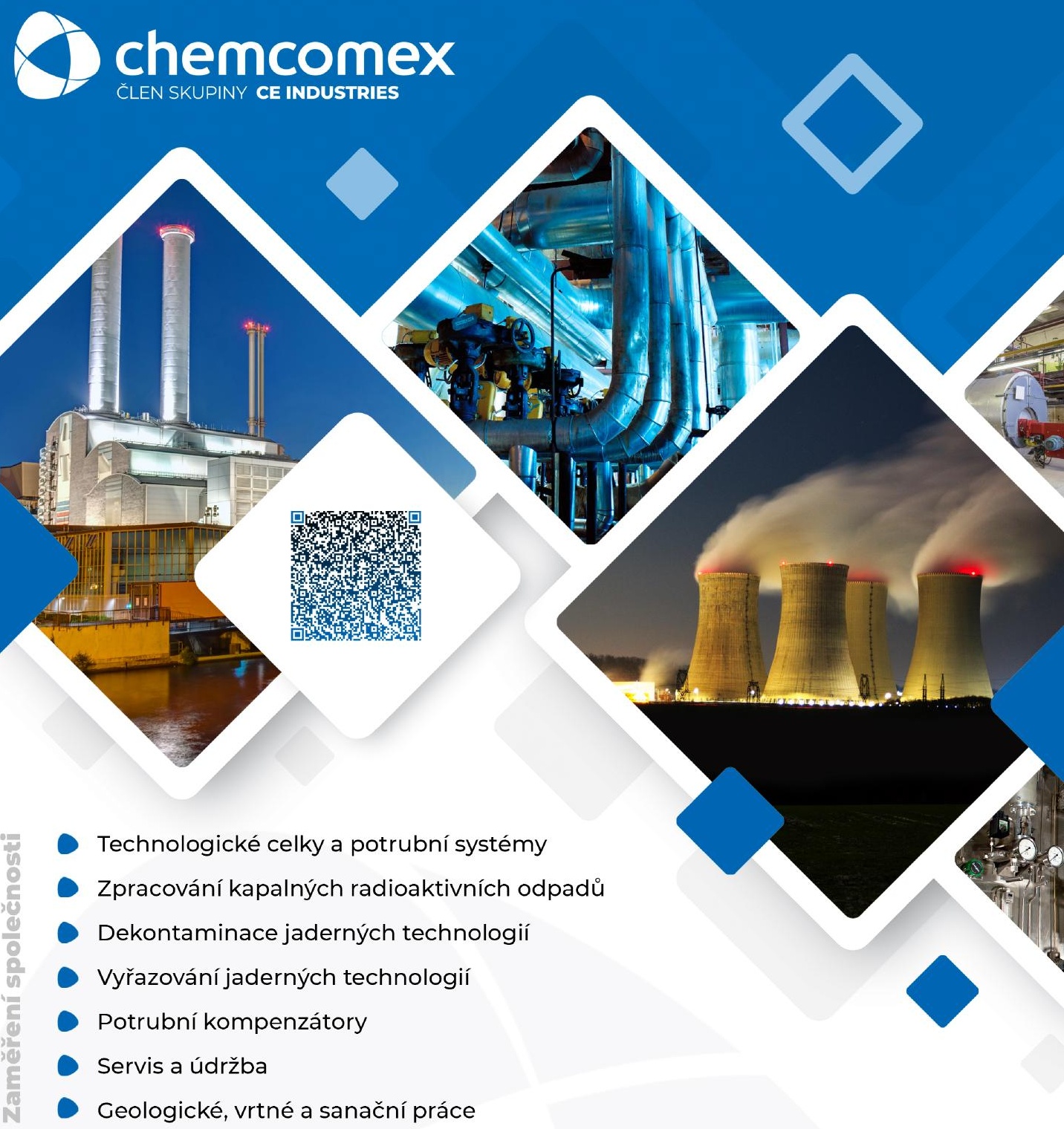

www.chemcomex.cz | info@chemcomex.cz

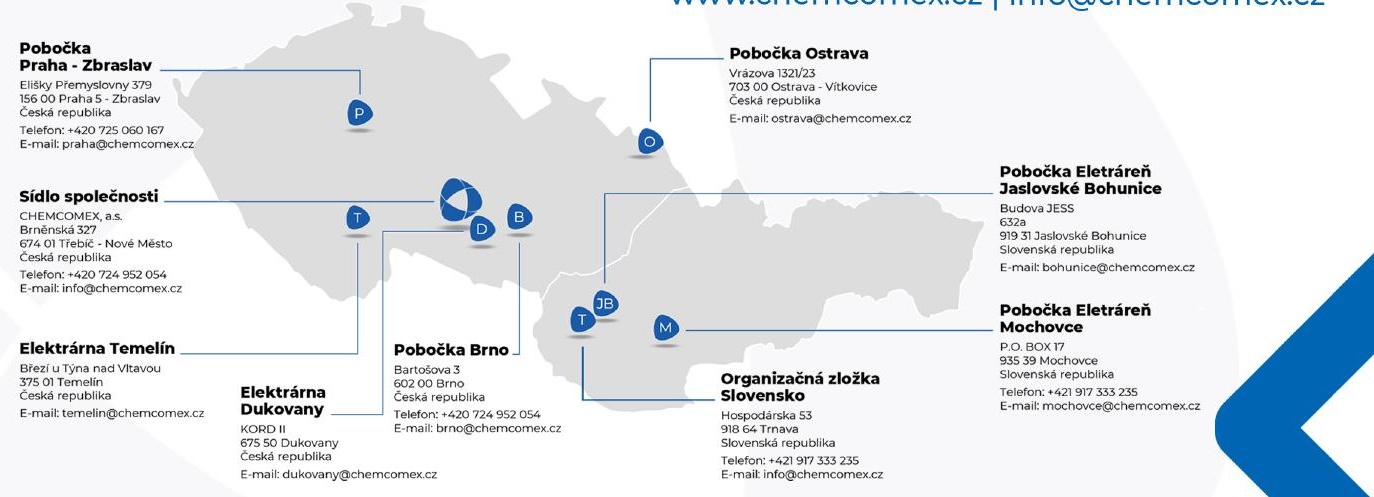




\section{nUVIATECH}

KOMPLEXNÍ ŘEŠENÍ

\section{PRO APLIKACE IONIZUJÍCÍHO ZÁŘENÍ V MEDICÍNĚ}

Jedinečné portfolio technologií a služeb NUVIA

Prístrojové a laboratorní vybavení pro nukleární medicínu

Služby radiační ochrany a osobní dozimetrie

Nakládání s radioaktivním odpadem

Stínicí konstrukce pro ochranu před zářením

Softwarová rešení

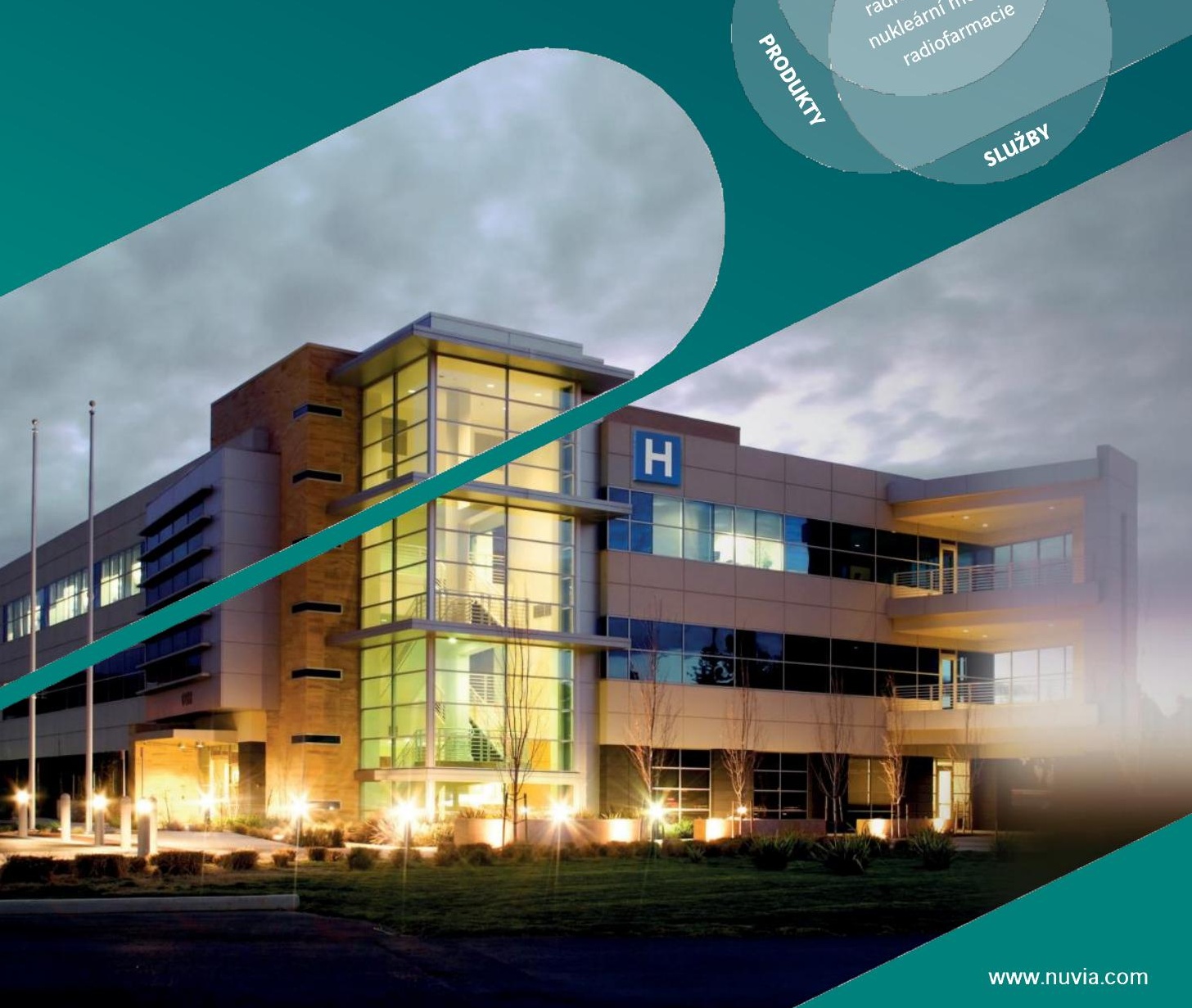




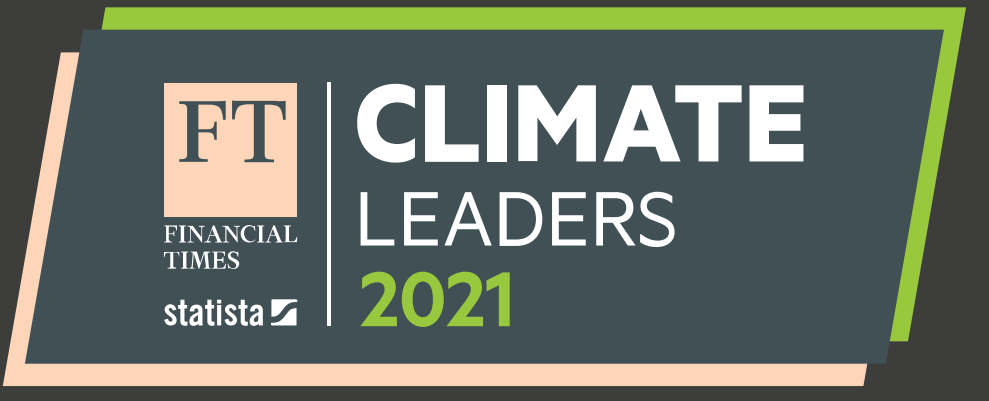

\section{Sme}

európsky

klimatický

líder

\section{Q SLOVENSKÉ ELEKTRÁRNE}




\section{V $=$ \\ VF NUCLEAR}

\section{Jsme významným světovým výrobcem a dodavatelem ZAR̆IZZENÍ A SYSTÉMŮ PRO RADIAČNí OCHRANU A KONTROLU}

Navrhujeme, vyvijíme a vyrábíme výkonná, citlivá a přesná zařizení, která spolehlivě detekují ionizující záření a chrání tak bezpečí lidí, věcí, pracovního prostředí, vybavení a citlivé provozní technologie.
Při naši práci využiváme high-tech materiály. Integrujeme chytré technologie a pokročilé funkce. Běžně stavíme a instalujeme rozsáhlá systémová řešeni po celém světě.

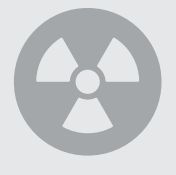

JADERNÉ ELEKTRÁRNY

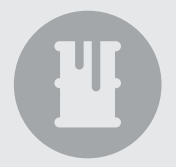

RADIOAKTIVNI ODPADY

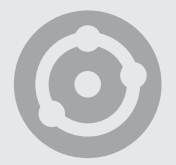

VÝZKUMNÁ CENTRA
Komplexní radiační monitorovací systémy pro výstavbu nových a rekonstrukci stávajících jaderných bloků. Likvidace a vyřazování jaderných bloků z provozu. Dodávka zařizení pro výzkumné a tréninkové jaderné reaktory.

Třidění a likvidace zdrojů ionizujícího záření. Zařízení pro charakterizaci pevných radioaktivních odpadů a jejich uvolňování do životniho prostředí. Systémy pro kapalné radioaktivní odpady. Osobní dozimetrie.

vývoj, výroba a instalace měřících systémů včetně integrace měřícich výsledků do uceleného systému monitoringu radiační situace pro pracoviště s výzkumnými nebo tréninkovými reaktory. Poskytování záručního a pozáručního servisu prípadně poskytováni služeb spojených s údržbou systémů.

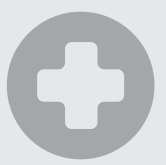

ZDRAVOTNICTVÍ
Dodávky a instalace radiačních monitorovacích systémů, výroba ručnich a přenosných zařizení. Měřeni kontaminace osob a předmětů. Služby osobni dozimetrie.

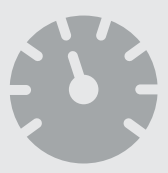

KALIBRAČNI LABORATOR̆E

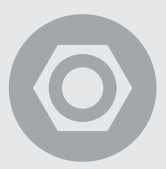

PRŮMYSL
Návrh a realizace a vybavení kalibračnich laboratoři. Výpočty a dodávky stínění. Vývoj a výroba ozařovačů a kalibračnich lavic. Kalibrace dozimetrických přistrojů. Dodávky uzavřených radionuklidových zdrojů.

Dodávky komplexnich systémů pro monitorování technologií, které využívají zdroje ionizujícího záření v jakékoli formè. Návrh a vybavení pracoviště průmyslových ozařoven, polohorkých a horkých komor a dalších ucelených průmyslových provozů. 
